https://helda.helsinki.fi

\title{
Latest advances on bacterial cellulose-based materials for wound healing, delivery systems and tissue engineering
}

\section{Carvalho, Tiago}

2019-08-29

Carvalho , T , Guedes , G, Sousa , F L , Freire , C S R \& Santos , H A 2019 , ' Latest advances on bacterial cellulose-based materials for wound healing, delivery systems and tissue engineering ' , Biotechnology Journal , vol. 14 , no. 12 , 1900059 . https://doi.org/10.1002/biot.201900059

http://hdl.handle.net/10138/327357

https://doi.org/10.1002/biot.201900059

acceptedVersion

Downloaded from Helda, University of Helsinki institutional repository.

This is an electronic reprint of the original article.

This reprint may differ from the original in pagination and typographic detail.

Please cite the original version. 


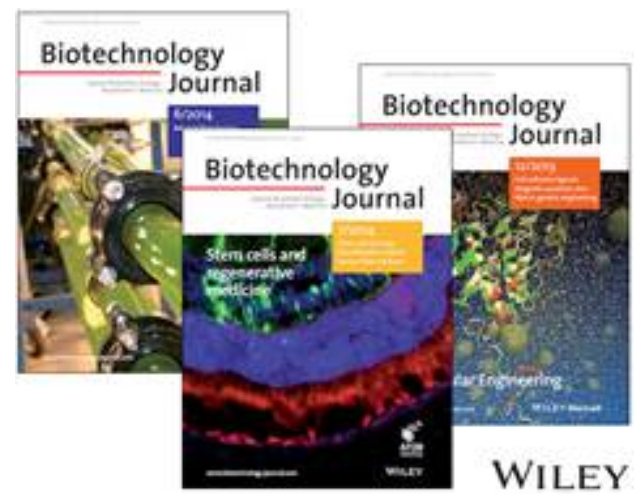

\section{Latest advances on bacterial cellulose-based materials for wound healing, delivery systems and tissue engineering}

\begin{tabular}{|r|l|}
\hline Journal: & Biotechnology Journal \\
\hline Manuscript ID & biot.201900059.R1 \\
\hline Wiley - Manuscript type: & Review \\
\hline Date Submitted by the & n/a \\
\hline Complete List of Authors: & $\begin{array}{l}\text { Carvalho, Tiago; University of Aveiro } \\
\text { Guedes, Gabriela; University of Aveiro } \\
\text { Sousa, Filipa; University of Aveiro } \\
\text { Freire, Carmen; University of Aveiro } \\
\text { Santos, Hélder ; Helsingin Yliopisto }\end{array}$ \\
\hline Primary Keywords: & Biomaterials, Medical biotechnology, Nanobiotechnology \\
\hline Secondary Keywords: & Bacteria, Biopolymers, Drug delivery, Tissue engineering, Bioengineering \\
\hline Additional Keywords: & $\begin{array}{l}\text { Bacterial cellulose; Biomedical applications; Drug delivery; Regenerative } \\
\text { medicine; Wound healing }\end{array}$ \\
\hline &
\end{tabular}

\section{SCHOLARONE \\ Manuscripts}




\section{Reply to Reviewers' and Editorial's comments}

\section{Review Editor: Rehm, Bernd}

There were no comments from the Review Editor.

\section{Reviewer \#1}

This is a well-done manuscript. It is scientifically sound, covering all current and latest information regarding BC applications in biomaterials and tissue engineering. There are some minor changes that need to be addressed:

R.: We thank the reviewer for the recommendation and time spent in reviewing our work, and for the insightful commentaries that will undoubtedly help us to improve the overall quality of the manuscript.

1. combining section 2.1 and section 2.7.3 to be 2.7.3 since both are related to skin and wound healing.

R.: As suggested, sections 2.1 and 2.3.7 were combined into section 2.2.1. Please, note that with this change, two tables and two figures switched places: Table 1 is now Table 2, Table 2 is now Table 1, Figure 1 is now Table 2 and Figure 2 is now Table 1.

2. Sections 1.1 and 1.2 are too long given that most of reviews on BC start with these sections and the same information is being repeated in here too. It is uninteresting and making the paper less focused. One way to do this is to refer readers to other insightful reviews on BC for physical properties and synthesis.

R.: We thank the reviewer for the suggestion. As recommended, sections 1.1 and 1.2 were shortened by removing some information that was not crucial for the topic of the review. There were already some referenced reviews cite in our review that better cover the production of BC and its properties. 


\section{Reviewer \#2}

The review summarizes the research on three important aspects of bacterial cellulose. There are certain grammatical errors. Please check the references with respect to author names and sequence.

R.: We thank the reviewer for the recommendation and time spent in reviewing our work, and for the insightful commentaries that will undoubtedly help us to improve the overall quality of the manuscript.

As suggested, grammatical errors in the manuscript were corrected and where needed, italics were added. In addition, the references were checked, and it was noticed an error in the authors, and some errors in the pagination of the articles. Their respective corrections were performed. 
DOI: $10.1002 /(($ please add manuscript number $))$

\section{Article type: Review}

Latest advances on bacterial cellulose-based materials for wound healing, delivery systems and tissue engineering

Tiago Carvalho ${ }^{1}$, Gabriela Guedes ${ }^{1}$, Filipa L. Sousa, Carmen S. R. Freire, Hélder A. Santos*

[*] T. Carvalho, G. Guedes, Prof. H. A. Santos

Drug Research Program, Division of Pharmaceutical Chemistry and Technology, Faculty of Pharmacy, University of Helsinki, Helsinki, FI -00014, Finland

[*] Prof. H. A. Santos

Helsinki Institute of Life Science (HiLIFE), University of Helsinki, Helsinki, FI -00014, Finland

T. Carvalho, G. Guedes, Dr. F. L. Sousa, Dr. C. S. R. Freire

Department of Chemistry, CICECO-Aveiro Institute of Materials, University of Aveiro, 3810-193 Aveiro, Portugal

${ }^{1}$ These authors contributed equally to this work.

* Corresponding author. helder.santos@helsinki.fi (H. A. Santos)

Keywords: Bacterial cellulose; Biomedical applications; Drug delivery; Regenerative medicine; Wound healing. 


\begin{abstract}
Bacterial cellulose (BC) is a nanocellulose form produced by some non-pathogenic bacteria. $\mathrm{BC}$ presents unique physical, chemical and biological properties that make it a very versatile material and have found application in several fields, namely in food industry, cosmetics, and biomedicine. This review overviews the latest state-of-the-art usage of $\mathrm{BC}$ on three important areas of the biomedical field, namely delivery systems, wound dressing and healing materials, and tissue engineering for regenerative medicine. $\mathrm{BC}$ will be reviewed as a promising biopolymer for the design and development of innovative materials for the mentioned applications. Overall, $\mathrm{BC}$ is shown to be an effective and versatile carrier for delivery systems, a safe and multi-customizable patch or graft for wound dressing and healing applications, and a material that can be further tuned to better adjust for each tissue engineering application, by using different methods.
\end{abstract}




\section{Introduction}

The biomedicine research field aims to find biomimetic structures and processes that aids to surpass and improve the actual shortcomings faced in the treatment of illnesses and diseases, leading to great investment in the research in this field and related areas. ${ }^{[1]}$ As a result of this intensive investigation, a great diversity of materials have arisen as potential candidates for biomedical applications. Among them, natural biopolymers such as bacterial cellulose (BC) have found a large diversity of applications and have been broadly studied, due to their similarities to native tissues. ${ }^{[1,2]}$

Cellulose, a linear biopolymer composed by glucose units linked through $\beta(1,4)$ glycosidic bonds, ${ }^{[3]}$ is an intrinsically biodegradable and biocompatible polymer that is widely known as the most abundant polymer in the planet. ${ }^{[4,5]}$ Cellulose is mainly found in the plant's cell wall and is one of its main structural elements. However, this biopolymer can also be synthesized by tunicates, algae and some bacteria. ${ }^{[6,7]}$ Its physical properties, such as molecular weight, degree of crystallinity, and crystalline state are highly variable and dependent on the respective source and extraction procedure. ${ }^{[5]}$ Other characteristic properties, such as biodegradability, chirality, hydrophilicity, and the ability for chemical modifications are imparted by its molecular structure. ${ }^{[4]}$

Among the different cellulose sources abovementioned, cellulose produced by nonpathogenic bacteria has been attracting increasing interest, especially in biomedicine, ${ }^{[8]}$ due to its unique properties (described in detail in Section 1.2.). Thus, this review aims to provide an overview of the recent advances in the use of $\mathrm{BC}$ in biomedical applications. To provide a comprehensive understanding of the topic, we will first briefly describe the $\mathrm{BC}$ biosynthesis and properties.

\subsection{BC biosynthesis}

Several non-pathogenic bacteria are able to produce BC, however, Komagataeibacter medellinensis (former Acetobacter xylinum) is known as the most efficient producer. ${ }^{[1,6,9-}$ 12] On its own, the biosynthesis of cellulose can serve several purposes to the bacterium, from physiological, mechanical and chemical stability protection, to the improvement of interactions and nutrient diffusion. ${ }^{[1]} \mathrm{BC}$ synthesis starts on the cellular membrane, where chemically activated glucose is polymerized by cellulose synthase. ${ }^{[6,10]}$ On the extracellular space, the glucose chains are organized into parallel structures through van der Waals and hydrogen bonds, forming fibers. ${ }^{[1,6,13,14]}$ 
$\mathrm{BC}$ production is mainly performed in nutrient-rich culture media, either static or agitated. These two methods for $\mathrm{BC}$ production originate structures with distinct morphologies, thus the choice of the method used will depend on the final application envisaged. ${ }^{[14-16]}$ In the production of $\mathrm{BC}$ under static culture, a pellicle is originated, while in an agitated culture, suspended fibers, irregular pellets, or even spheres are produced. ${ }^{[14-16]}$ Although agitated culture is faster relatively to static culture, the production yields are lower and there is a higher probability of mutations in the bacteria. ${ }^{[14,16]}$ By using more complex methods, $\mathrm{BC}$ can also be produced in the form of hollow spheres, namely through the use of microfluidics, ${ }^{[17]}$ or water-in-oil emulsion techniques. ${ }^{[18]}$ A novel and innovative way to obtain fine-controlled and complex shapes of BC were recently described by Schaffner et al. ${ }^{[19]}$ They used 3D bioprinting where a biocompatible hydrogel, with adjusted rheological properties, allowed the immobilization of Acetobacter xylinum. This bacteriacontaining hydrogel was then printed into a predesigned 3D shape. The following incubation enabled the formation of BC scaffolds on nonplanar surfaces. This new strategy can open new horizons regarding the development of scaffolds and membranes with complex architectures for diverse types of biomedical applications, not accessed by common techniques.

\subsection{BC properties}

$\mathrm{BC}$ exhibits superior properties that make it suitable for use in biomedical applications, namely its higher purity, the ultrafine network structure, higher crystallinity, and improved mechanical properties, which arise from the nanofibrils $3 \mathrm{D}$ network. ${ }^{[6-9,11]}$ The resultant nanofibers have a high surface area, which altogether with the hydrophilic nature of BC, resulting in a high water holding ability and adhesion. ${ }^{[14]}$ Several properties must be considered in the design of a biomaterial, namely the biocompatibility, the ability to promote cellular interaction and the development of the tissue, the biodegradability and bioabsorbability, interconnected porous structure, and good mechanical properties able to support loads and high resistance to wear. These parameters will be briefly addressed below; however, since this is not the focus of this review other reports can be accessed to obtain more detailed information on these topics. ${ }^{[1,20]}$

Important features that make BC biocompatible is its chemical nature and its nanofibrillar architecture that resembles an extracellular matrix (ECM) component, specifically the collagen. ${ }^{[21]}$ Moreover, the polysaccharide nature of $\mathrm{BC}$ reduces or eliminates the immunogenic response. ${ }^{[20]}$ Several studies proved the biocompatibility of BC-based 
materials in diverse biomedical applications, ${ }^{[2,20,21]}$ as well as low genotoxicity and cytotoxicity. ${ }^{[22]}$

In some types of biomedical applications, such as skin, wound healing and bone scaffolds, the lack of bioabsorbability can be a desirable property. ${ }^{[10]}$ Despite the existence of some slow non-enzymatic hydrolysis of cellulose, the human body is not able to degrade cellulose due to the absence of cellulases, ${ }^{[10,20]}$ making BC suitable for use in applications that requires long term support. ${ }^{[1]}$ However, to extend the range of applicability of $\mathrm{BC}$, several attempts have been made to make $\mathrm{BC}$ bioabsorbable, for example, by oxidation of cellulose, ${ }^{[20,23,24]}$ or by incorporation of cellulases within BC. ${ }^{[25,26]}$

The control over the macro, micro, and nanostructures is another important feature to take in consideration in different biomedical applications. Important properties in the micro and nanostructure are the porosity, surface chemistry, and fiber orientation. ${ }^{[20]}$ Some of these characteristics are not the ideal for every application, and sometimes it is necessary to tailor BC for a specific use. This can be accomplished through the modification of BC. There is a great diversity of modifications that can be applied to BC, which can be grouped in two distinct classes: in situ and ex-situ modifications, ${ }^{[27,28]}$ consisting respectively in the incorporation of exogenous molecules that are added to the culture medium during $\mathrm{BC}$ biosynthesis, ${ }^{[29-33]}$ or performed after the $\mathrm{BC}$ is produced and purified, and can be carried out either by chemical or physical methods. ${ }^{[28]}$ Porosity is a great concern in applications such as the development of scaffolds for cell growth. However, $\mathrm{BC}$ is naturally produced in the form of a dense mesh, hindering cell migration into the material. Thus, several approaches have been used to increase porosity on BC membranes, mainly through the use of porogens (i.e., materials added to the culture media, that become incorporated in the $\mathrm{BC}$ membrane, being later removed, leaving pores behind, without significantly damaging the material). ${ }^{[34]}$ The high density of hydroxyl groups at the $\mathrm{BC}$ surface, making it simple to chemically modify this substrate. Therefore, there have been several attempts to change the surface chemistry of $\mathrm{BC}$, taking advantage of this specific property. Oxidation mediated by (2,2,6,6-Tetramethylpiperidin-1-yl)oxyl (TEMPO), phosphorylation, and succinylation are examples of this type of modifications. ${ }^{[1,35]}$ Usually, BC nanofibers are randomly orientated, however, there have been several attempts to align the BC nanofibers, namely using microfluidic channels, ${ }^{[36]}$ a scaffolding of nematic ordered cellulose with aligned cellulose fibers, ${ }^{[37]}$ or external electromagnetic fields ${ }^{[38]}$ to direct the bacteria motion and achieve fiber alignment. 
Naturally, BC exhibits high mechanical properties, ${ }^{[4,9,12]}$ such as Young's modulus of about $118 \mathrm{GPa}$ for a single BC filament, tensile strength of $200-300 \mathrm{MPa}$, and a stressstrain behavior similar to that of the soft tissues. ${ }^{[4,9,10,12]}$ For these reasons, BC is widely used as reinforcement material and is a good candidate for applications desiring a high mechanical performance material. ${ }^{[10,12]}$

\section{Applications}

\section{1. $\quad B C$ in systems for the delivery of drugs and other molecules}

As a result of the non-bioabsorbable nature of $\mathrm{BC}$ in the human body, the use of $\mathrm{BC}$ as delivery systems for drugs and other molecules have been limited essentially, ${ }^{[39]}$ as can be observed from Table 1, to dermal patches ${ }^{[40]}$ and oral capsules. ${ }^{[41,42]}$ For the development of dermal patches, the porosity of BC is easily exploited to load drugs with different features, ranging from antibacterial activity ${ }^{[43]}$ to anticancer properties. ${ }^{[44]}$ Additionally, $\mathrm{BC}$ can be further optimized by chemical modifications with other (bio)polymers, or by producing BC-based materials, to better control its cargo release, burst, ${ }^{[18]}$ or sustained release,,${ }^{[4]}$ and even responsive releases to $\mathrm{pH},{ }^{[46]}$ temperature ${ }^{[47]}$ or electromagnetism. ${ }^{[48]}$ For the development of oral formulations, $\mathrm{BC}$ has been used in combination with other biopolymers for a controlled release of the drug within, ${ }^{[41]}$ e.g. for the oral delivery of insulin, ${ }^{[42]}$ and hydrophobic and hydrophilic drugs alike. ${ }^{[49]}$

Most dermal patches are prepared by simply soaking a pure BC membrane, ${ }^{[40,43]}$ or a BC-based composite, ${ }^{[50]}$ in a solution of the compounds of interest. In order to achieve multiple desired results, these membranes can be loaded with more than one compound at once. Morais et al. ${ }^{[51]}$ loaded BC membranes with ionic liquids based on phenolic acids, for the development of patches for skin treatment. Biological assays showed that these patches have both high antioxidant and anti-inflammatory activities, in addition to biocompatibility and sustained release of its cargo. Other study that demonstrates that a BC membrane can have multiple actions, is the study performed by Badshah et al., ${ }^{[52]}$ where $\mathrm{BC}$ was modified with acetic anhydride, to be able to be loaded with one of two drugs with very different natures, one poorly water-soluble, and the other highly water-soluble. Before the reaction, the $\mathrm{BC}$ membranes were soaked with acetic acid. Then, the membranes were impregnated with either an acetic acid solution of the poorly watersoluble drug or an aqueous solution of the water-soluble drug. Furthermore, the drug 
loading capacity and drug release rate where further controlled by the drying method of the membranes (freeze-drying vs. oven drying). In another study, ${ }^{[50]}$ two different molecules were loaded in a BC-based composite, specifically serum albumin, which modulated the release of the other molecule, levofloxacin, reducing its cytotoxicity to undetected levels, without losing its antibacterial activity. These three mentioned studies, ${ }^{[50-52]}$ are a great example of the versatility of BC to further develop dermal patches for drug delivery systems, that can be laden with different molecules while maintaining properties of interest.

Studies of drug delivery systems for oral administration also benefited from exploiting $\mathrm{BC}$ characteristics. For the first time, BC capsules for oral administration were prepared by Ullah et al. ${ }^{[41]}$ Capsule shells of pure BC or BC conjugated with starch, hydroxypropylmethylcellulose or carboxymethyl cellulose were prepared and used for encapsulation of salbutamol sulfate. The capsules of pure BC demonstrated a burst release of the drug, whereas the ones formulated with other polymers showed controlled drug release ( $6 \mathrm{~h}$ for the one formulated with carboxymethyl cellulose). Additionally, the capsules formulated with carboxymethyl cellulose showed to better prevent drug leakage at a lower $\mathrm{pH}$. This study showed the versatility of BC for either burst or controlled release of a contained drug. In order to prepare a tablet for oral administration of both watersoluble and poorly water-soluble drugs (tizanidine and famotidine, respectively), Badshah et al., ${ }^{[49]}$ used $\mathrm{BC}$ as the sole excipient, compared to the multi-excipient commercial formulations. The authors prepared different formulations of drug-loaded discs by only changing the loading and drying methods. The ones containing the watersoluble drug were immersed in an aqueous solution of the drug, while the ones containing the poorly water-soluble drug, were immersed in an acetic acid-methanol solution of the drug. All formulations showed a superior burst release for both drugs, contrasting to the slower release of tizanidine by the commercial product. Taking examples from these studies, ${ }^{[41,49]}$ novel formulations can be designed to prepare drug delivery systems for oral administration that need to exploit the properties of $\mathrm{BC}$, such as the ones presented: water insolubility and high water-holding capacity, ultrafine fiber network and high porosity, and ease of production into desired shapes.

\subsection{Tissue engineering and regenerative medicine}

\subsubsection{In vivo wound dressing, healing and skin tissue engineering studies}


There are various well-known characteristics of BC that can be exploited to develop novel dressings for wound healing, being it full-thickness wounds or third-degree burns, where the extent of these injuries past the dermis and epidermis into subcutaneous tissue. Some of these well-known $\mathrm{BC}$ characteristics are the biocompatibility, the mechanical resilience, the easiness to be laden with drugs or nanoparticles, and the ability to moist the wounded area, while absorbing formed exudates. It is also a physical barrier against microbes and other external aggressions, while allowing gas exchange. It also has the capacity of being removed from the wound without pain and without damaging the newly formed tissue. ${ }^{[10,39,53]}$ Additionally, when used as a wound dressing, BC optical transparency provides the possibility of using laser-based imaging diagnosis, such as multiphoton tomography, optical coherence tomography, and confocal laser scanning microscopy, allowing a non-invasively follow-up of the wound healing development. ${ }^{[54]}$

The incorporation of drugs, ${ }^{[55,56]}$ nanoparticles, ${ }^{[57,58]}$ biopolymers, ${ }^{[59,60]}$ or even cells ${ }^{[61]}$ that either have antimicrobial activity or induce the severed tissue regeneration to be faster, into BC based materials, demonstrated synergistic activity. Table 2 summarizes the types of BC-based dressings developed during the last years, as well as the outcomes of the in vivo tests. These studies were mainly performed in full-thickness wounds, third-degree burns, and femoral artery injuries, and the performance of each formulation was evaluated through histological imaging, wound closure measurement for skin wounds, and blood loss for the femoral artery injuries.

Research on quenching uncontrolled hemorrhages has also been done in the past few years, because inexpensive hemostatic agents that can be easily applied, with good effectiveness at stopping hemorrhages, are still to be achieved. ${ }^{[62]}$ With this as objective, biocomposite dressings of $\mathrm{BC}$ and chitosan with an electrospun upper layer of silk fibroin or silk fibroin/phosphatidylcholine were prepared. ${ }^{[62]}$ Some of these bilayer dressings were loaded with different hemostatic agents (kaolin, vitamin $\mathrm{K}$, and protamine sulfate). Comparative studies were made against standard gauze on Sprague-Dawley rats. All dressings except the kaolin-loaded one, showed satisfying results regarding the quantifications of the activity of lactate dehydrogenase, an enzyme released during tissue injury, the time elapsed to hemostasis, blood loss and animal mortality were evaluated. This study was repeated by the same group, but this time using diabetic Sprague-Dawley rats as animal models, ${ }^{[63]}$ due to the risk of bleeding complications that arise from hemostatic irregularities induced by this disease. The prepared dressings and the executed 
procedures were the same as the ones in the former study, showing once more the effectiveness of these hemostatic agents, with extremely similar results in terms of mortality, blood loss, time to hemostasis, and lactate dehydrogenase activity, of all prepared formulations, except for the one loaded with kaolin.

The nanostructure of $\mathrm{BC}$-based formulations was reported to be an important characteristic for the quality of the wound healing process, by using patterned BC membranes that were prepared on top of soft templates with grooves of different width sizes $(10,30$ and $50 \mu \mathrm{m})$, and all with a depth of $10 \mu \mathrm{m} .{ }^{[64]}$ Since the in vitro studies with these patterned membranes showed better results for the ones with $10 \mu \mathrm{m}$ thickness, these were furtherly used on in vivo studies, where the wounds on the rats treated with this patterned membrane showed to be healed after twenty-one days, with a scar with thickness half of the one formed on the untreated wounds and the wounds treated with gauze (scar thickness of less than $300 \mu \mathrm{m}$ vs. $600 \mu \mathrm{m}$ ), and around $100 \mu \mathrm{m}$ less than the scar formed on the wounds treated with non-patterned BC.

Another study that showed the importance of the nanostructure of the dressing was when hollow BC microspheres were produced with the objective of creating an injectable scaffold for wound healing. ${ }^{[17]}$ In vivo studies were performed on rats by inflicting a wound on the back of each animal, and then by covering the non-control specimens with a bulk BC membrane, non-hollow BC microspheres or hollow BC microspheres. This study reported that after 7 days, there was no difference in the wound size between the controls and the ones covered with bulk BC. Both rat populations showed to have a better recovery when microspheres were used with the best results observed for the hollow ones. The authors state that this difference in wound recovery speed is due to the higher porosity observed on the hollow BC microspheres.

Similarly to this last study, a biocomposite was prepared by incorporating gelatin microspheres within recovered $\mathrm{BC}$, followed by the dissolution of the gelatin, leaving behind sponge-like hollow spaces within the recovered $\mathrm{BC}$, while covering the same $\mathrm{BC}$ with a layer of gelatin, increasing the biocompatibility of the material.[62] Using this biocomposite and an untreated $\mathrm{BC}$ membrane, the in vivo studies were performed, first by inflicting a full-thickness wound on each animal model, and then by covering the wound with the different dressings. After 2 weeks, the wounds treated with the composite dressing were healed, comparing to the $60 \%$ wound closure of the ones treated with BC 
only. This study, once again, showed the importance of the existence of pores on woundhealing patches. However, since the prepared composite also had gelatin covering the surface of its pores, it would be beneficial to additionally compare it to a gelatin-covered BC membrane.

BC-based dressings continue to show high healing performance over conventional materials, such as gauze, without considering minimizing the pain suffered by the patient both during the first days after the wound was inflicted or at the time of the dressing removal. ${ }^{[65]}$ During the last years, the studies using BC as a base for the development of wound healing materials kept showing its versatility. BC can be loaded with different components that can be either antimicrobial or regeneration-inductive agents. Easily, BC can have its $\mathrm{pH}$ adjusted in order to provide a better environment for tissue regeneration. ${ }^{[66]}$ Furthermore, $\mathrm{BC}$ can be designed to be a structure which physical and chemical conditions can be adjusted, improving the extracellular environment, leading to a faster wound healing.

Similarly to wound healing applications, skin tissue engineering comprises the restoration of the two main layers of skin, the epidermis and the dermis. The nanofibrils of BC hydrogels resemble the fibrillar component of the native ECM. Furthermore, BC has great retention moisture content ability and suitable mechanical properties. As a result of its similarity with skin, $\mathrm{BC}$ has been widely used in the reconstruction of this tissue. ${ }^{67]}$

A novel composite aiming to enhance the adhesion of skin fibroblasts on $\mathrm{BC}$ surface was developed by the in situ or post modification of BC with keratin. ${ }^{[68]}$ The in situ approach consisted in the addition of keratin to the bacteria culture medium. Moreover, the postmodification involved the impregnation of keratin in the $\mathrm{BC}$ membrane after its biosynthesis and purification. Both approaches produced suitable composite materials, which demonstrated a good attachment of dermal fibroblasts and maintenance of original epithelial morphology of keratinocytes on the surface of BC-keratin composites.

Despite the as-referred advantages of BC for skin applications, its opaque form limits its use in daily life applications. TEMPO-mediated oxidation of BC originates a transparent form dispersed in water. To evaluate the suitability of TEMPO-mediated BC nanofibers for application in the skin, Jun et al. ${ }^{[69]}$ studied its physical properties and filtrating particulate matter ability on a porcine skin model 
a

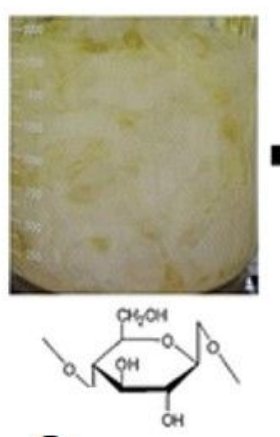

C

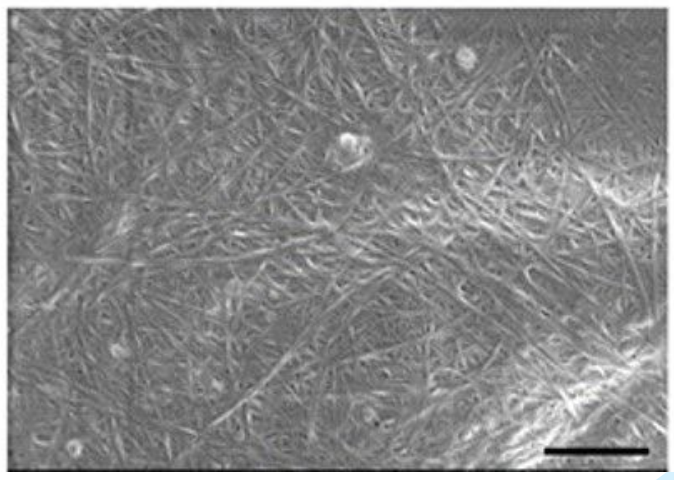

b
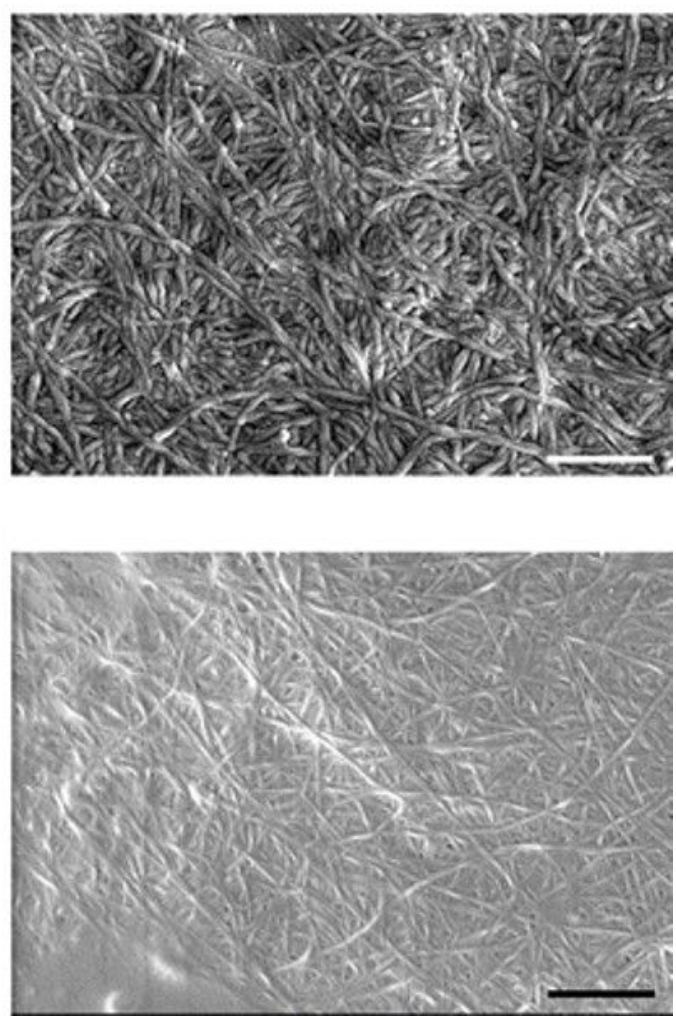

Figure 1). TEMPO-mediated BC nanofibers exhibited adherence to the skin surface, and high tensile strength and high water-holding ability. Moreover, it prevented the direct adhesion of particulate matter on the skin.

\subsubsection{Cardiovascular implants}

$\mathrm{BC}$ is a material of interest to develop cardiovascular implants, because of its already described physical and biological properties, as well as the possibility to produce it in various forms and shapes that better suit the application, either to produce grafts, patches or hydrogels for either vascular grafting or regeneration.

While there are gold-standard materials to produce large and medium-diameter vascular grafts, there is still a need to develop a small-diameter vascular graft $(<6 \mathrm{~mm})$, especially ones with long-term patency. ${ }^{[70]}$ As a result of the innate characteristics of $\mathrm{BC}$ as a biomaterial, it has been used to prepare small-diameter vascular grafts, by using different techniques. These techniques can be as simple as piercing BC with a metallic skewer with the right diameter and use it as a mold, ${ }^{[70]}$ or cultivating the $\mathrm{BC}$ inside a double cylinder bioreactor. ${ }^{[71]}$ More elaborated techniques were also reported, such as cultivating BC 
layer-by-layer around a guide bar, ${ }^{[72]}$ or preparing a self-rolling $\mathrm{BC}$ membrane with shape-memory. ${ }^{[73]}$

Following the simplest and the most inexpensive method, based on the use of a skewer, ${ }^{[70]}$ pure $\mathrm{BC}$ was used to prepare the graft, showed to be patent after one month of in vivo implantation. However, after two months the grafts were obstructed by thrombi and the experiment was terminated. The authors suspected that the obstruction was due to animal handling, meaning that more studies needed to be performed.

In the study where $\mathrm{BC}$ was produced within a double cylinder bioreactor, ${ }^{[71]}$ the authors prepared a BC-heparin biocomposite that showed better characteristics for a patent graft than pristine $\mathrm{BC}$ : anticoagulation activity, less platelet adhesion, very slow plasma clotting, and good cell viability. Since this biocomposite showed inferior mechanical properties, the authors further prepared a BC-heparin-chitosan biocomposite, with mechanical characteristics that surpassed the ones from the previous grafts. However, it showed slightly inferior cell viability. The authors describe both biocomposite grafts as viable for the development of small-diameter vascular grafts and added that the latter graft was considerably interesting due to the chitosan bioresorbability, leading to a slow release of heparin.

In another study where the BC graft was produced layer-by-layer, ${ }^{[72]}$ the aim was to prepare a graft with a smoother and compacter inner wall than a graft where the morphology of the inner wall was not controlled. Results showed increased patency from 67 to $80 \%$ in 9 months period, while an antiplatelet drug was being orally administrated to the animals. Since it was a proof-of-concept study, where few animals were used and few characterizations were performed, the authors stated that a more extensive study was needed, using this promising technique of small diameter vascular graft production.

Using a totally different method to prepare a small diameter shape-memory BC tube, ${ }^{[73]}$ as shown in Figure 2a and Figure 2c. This can be further exploited to load the same graft with different cells (Figure 2b) that will stay in layers after the membrane is rerolled (Figure 2d), which is a phenomenon of interest if one of the aims is to better mimic the different layers of a vessel. After in vivo implantation of a tube not loaded with cells, blood flow was confirmed to pass through the tube, and after 3 days, ultrasound images revealed that it was not possible to perceive the boundary between the tube and surrounding tissue, meaning that possibly the tube was encapsulated by the surrounding 
tissue. After 21 days, the tubes were excised, and it was observed the absence of thrombi formation and the absence of immune cells between the layers of the tube. With these promising results, the authors stated that this graft can be further exploited to develop small-diameter vascular grafts and that further experiments with cell-laden grafts must be performed in the future.

Aiming at quickening the re-endothelization of a severed vascular tissue, $\mathrm{BC}$ hydrogels with magnetic properties have been developed and characterized, since this kind of materials can recruit tissue-regenerating cells. ${ }^{[74,75]}$ The magnetic BC hydrogel was prepared by a simple method consisting of the immersion of the BC hydrogel in a solution containing iron II and III salts, following by in situ synthesis of magnetic iron nanoparticles. Even though these type of nanoparticles are used in magnetic resonance imaging, in higher concentrations they disrupt the mitochondrial respiratory chain and start to generate radical oxygen species (ROS). ${ }^{[74]}$ In order to evaluate the cell recruitment/cytotoxicity ratio of the magnetic BC hydrogels, a gradient concentration of magnetic Fe nanoparticles were prepared within the BC hydrogels, ${ }^{[75]}$ and it was observed by in vitro studies that for concentrations as low as $25 \mathrm{mM}$ there was a substantial cell recruitment, while maintaining a cell viability similar to the one of unmodified BC. Furthermore, for higher concentrations of these nanoparticles, cytotoxicity was observable, where for concentrations of nanoparticles of $100 \mathrm{mM}$ the cell viability was very low. In a different study, ${ }^{[74]}$ to prevent the induction of ROS production by these nanoparticles, magnetic BC was coated with poly(ethylene glycol) (PEG) by immersion. In vitro ROS quantification was observed to be around half on the PEG-coated magnetic $\mathrm{BC}$, as compared to the uncoated one.

In a different vein, Kołaczkowska et al. ${ }^{[76]}$ developed a BC-based regenerative implant to be used in cardiac and vascular surgeries by preparing several biocomposites of BC/hyaluronic acid/poly(vinyl alcohol) (PVA), using different methods: addition of hyaluronic acid or PVA to the $\mathrm{BC}$ culture media; $\mathrm{BC}$ impregnation with aqueous solutions of hyaluronic acid or PVA; BC impregnation in a given solution for 2 hours at $80{ }^{\circ} \mathrm{C}$; $\mathrm{BC}$ impregnation in a given solution and autoclaving it for 20 minutes at $121{ }^{\circ} \mathrm{C}$. After physical and biological characterization, the most promising patch was used in animal vascular surgery, showing greater durability than animal tissue, good biocompatibility, low thrombogenicity, and low hemolysis. However, the patch showed poor cell adhesion. 
This study was the first step for the development of a scaffold for regenerative medicine, and more studies need to be performed in the future.

$\mathrm{BC}$ has fantastic characteristics for tissue engineering applications, yet it lacks the capacity to develop proper vascularization, leading to cellular apoptosis. To attenuate this problem, Wang et al. ${ }^{[77]}$ developed a porous scaffold biocomposite of BC/gelatin, containing silk fibroin nanoparticles loaded with vascular endothelial growth factor (VEGF). The in vitro experiments demonstrated a continuous release of VEGF for 28 days and increased cell proliferation. Additionally, the in vivo experiments showed a substantial angiogenesis increase in the animal tissue patched with the developed scaffold.

\subsubsection{Dentistry applications}

For dental extraction and mucosal transplantation applications, bioabsorbability under physiological conditions and antibiotic loading are desirable. In this context, Weyell et al. ${ }^{[78]}$ studied the degradation and doxycycline release from $\mathrm{BC}$ membranes with different oxidation degrees. The BC oxidation was achieved with periodate and was performed for several reaction times and temperatures. The authors found that at a periodate concentration of $0.14 \mathrm{~mol} / \mathrm{L}$, a temperature of $25^{\circ} \mathrm{C}$ and $8 \mathrm{~h}$ of reaction, the membrane obtained was partially degraded and still did not compromise the loading and retention capacity of the dressing. Moreover, the antimicrobial activity of the oxidized BC membranes loaded with doxycycline maintained its efficiency against pathogenic oral bacteria and exhibited biocompatibility with L929 mouse fibroblasts.

Besides BC's chemical, physical and mechanical properties, it was previously reported that the presence of $\mathrm{BC}$ nanowhiskers quicken the hardening process of silicate cements, originating suitable composites for application in endodontics. ${ }^{[79]}$ To further study the $\mathrm{BC}$ 's potentialities in the endodontics field, namely its ability to improve the binding properties of mineral cements, Voicu et al. ${ }^{[80]}$ prepared BC-silicate composites cements that exhibited a faster setting time and high mineralization process in in vitro tests. Cell studies indicated that mesenchymal stem cell cultures adhered and proliferated and that there was no oxidative stress. This behavior made the composite developed, highly interesting for endodontics applications, namely in root channel obturation, perforated channel filling or dentine mineralization.

As a result of its self-attachment to surfaces, flexibility, and softness, BC can also be a good candidate in other dental medicine applications, such as temporal implant in dental 
extraction alveoli or wound dressing after mucosal implantation. ${ }^{[78]}$ However, although the recognized improved epithelialization and decreased inflammatory reactions during the use of BC-based periodontal dressing materials, ${ }^{[81,82]}$ the number of studies of its application in this area is scarce.

\subsubsection{Urethral implants}

The urethra, as a hollow organ exhibits an asymmetric structure, which can be divided in a stratified epithelium that acts as the barrier of the urethra, and in an organized subcutaneous layer that contains muscle cells and fibroblasts, providing strength and flexibility. ${ }^{[83]}$ There are several conditions and injuries that lead to a loss of urethra function. The scaffolds designed for urethral tissue engineering must respond to three basic principles: (1) mimic the ECM; (2) mimic the natural asymmetric structure accommodating a large number of cells in one side and acting as a barrier on the opposite side; and (3) be capable of resist to the mechanical requirements during the formation of the new tissue.

$\mathrm{BC}$ is a great candidate for urethral tissue engineering due to the mechanical and biological properties already mentioned, namely the similarities between the $\mathrm{BC}$ structure and the ECM, which may improve the cell adhesion and proliferation. ${ }^{[20]}$ Lima et al. ${ }^{[84]}$ and Maia et al. ${ }^{[85]}$ studied the application of pure BC membranes as urethral reinforcement in animal models, namely in Wistar rats and rabbits, respectively. In both studies, the BC membrane was well integrated into the urethral wall. Furthermore, Lima et al. ${ }^{[84]}$ reported the remodeling and strengthening of the urethral wall of the Wistar rats. Maia et al. ${ }^{[85]}$ found that the $\mathrm{BC}$ membrane was biocompatible, however, they also observed a decrease in the urethral wall thickness after 14 weeks of implantation and this way they were not able to conclude about the ability of $\mathrm{BC}$ to induce urethral reinforcement. More studies on this topic are needed to construct a higher level of evidence about the effect of BC membranes in urethral reinforcement.

The compact structure of pristine $\mathrm{BC}$ can lead to a lack of cell migration, penetration, and ingrowth. ${ }^{[86]}$ To overcome this issue, Lv et al. ${ }^{[87]}$ developed a nanofibrous scaffold by gelatinization of potato starch in the culture medium, and posterior addition of Gluconacetobacter xylinus to interrupt cellulose formation during static culture, creating more free spaces in the cellulose network. The prepared scaffold was cultured with muscle cells and then implanted in dog urethral defect models, exhibiting an enhanced 
wound healing of the tissues. With the goal of surpassing the as-referred disadvantage of $\mathrm{BC}$, the same team developed a bilayer scaffold constituted by a microporous network of silk fibroin (SF) and a nanoporous network of BC. ${ }^{[88]}$ The introduction of SF in the scaffold allows the ingrowth of the host tissues, while BC acts as a membrane to the retention of urine. The developed scaffolds exhibited biocompatibility and the ability to support cell adhesion and proliferation.

\subsubsection{Neural implants}

Injuries of the nervous system are a very serious concern. Nowadays, the gold standard for the regeneration of nerve injuries are the nerve autografts, a nerve collected from a less important part of the body. However, application of autografts presents several drawbacks, such as the need for a second surgery to harvest the nerve, the donor site morbidity in the secondary surgical site, the availability of donor tissue, and the low efficacy of treatment. ${ }^{[89,90]}$ Therefore, the last years have witnessed many efforts to improve neural regeneration, with tissue engineering playing a prominent role in the advances made in this field.

The materials used for such applications should present a 3D structure resembling the ECM and properties that enables the cellular attachment. ${ }^{[89]}$ Regarding these properties, $\mathrm{BC}$ has merged as a promising material in this field. For example, Geisel et al. ${ }^{[91]}$ produced $\mathrm{BC}$ with controlled topographies through bacterial culturing and molding with patterns. Subsequently, they studied the influence of BC controlled topographies in neural stem cells growth and differentiation and found that when cultured in randomly orientated $\mathrm{BC}$, the neurons exhibited a higher differentiation and surviving rate. The authors attributed this effect to the ECM like structure of the randomly orientated BC that became very smooth and dense surface in structured BC. Furthermore, they found out that randomly $\mathrm{BC}$ cultures presented a higher cell density than ECM-coated cover slips.

In a different study Altun et al. ${ }^{[92]}$ prepared bioinspired scaffolds by electrospinning of a $\varepsilon$-caprolactone/BC blend. The prepared scaffolds exhibited a well-defined and interconnected network with hollow micro/nanobeads, which closely reminds neurological networks, and showed to be non-cytotoxic, biocompatible and promoted cell adhesion. The dorsal root ganglia cells exhibited biocompatibility with the scaffolds since almost all of them were sticky and axon extended. Furthermore, the scaffolds presented a high supportive effect of dorsal root ganglia cells and enhanced neurite outgrowth, 
proving its potential to the creation of $3 \mathrm{D}$ guidance scaffolds to stimulate nerve regeneration.

A 3D-scaffold was prepared by Kim et al. ${ }^{[93]}$ by introducing graphene oxide (GO) nanoflakes into BC culture media, obtaining a nanocarbon hybridized structure. This process introduced structural modifications in the crystalline cellulose nanofibril and in their 3D-assembly. GO-BC scaffolds exhibited increased ability to support the primary neuronal cell culture in a way that resembles the in vivo environment in brain tissue. Furthermore, neuronal activity and long-term culture viability were also preserved.

Bioabsorbability is a key property for a neural scaffold. ${ }^{[89]}$ In this context, Hou et al. ${ }^{[94]}$ evaluated BC scaffolds with different oxidation degrees caused by ex-situ modifications through oxidation with $\mathrm{NaIO}_{4}$ to improve the bioabsorbability of BC. They obtained BC scaffolds with suitable mechanical properties, high porosity, and interconnected pores, as well as improved bioabsorbability. These scaffolds showed cellular and blood compatibility, demonstrating to be a potential candidate for application in peripheral nerve repair.

Epidural fibrosis and adhesion affect several nerves and cause recurrent pain in the back or limbs. The solution to this problem passes through the development of barriers to inhibit the compression of neural structures by postsurgical fibrosis. Wang et al. ${ }^{[95]}$ developed a barrier that consisted of a membrane of $\mathrm{BC}$ with exosomes from human umbilical cord mesenchymal cells (HUCMSC-Exos). The obtained membrane exhibited a 3D network structure, suitable mechanical properties, no cytotoxicity and biocompatibility in vivo. Furthermore, the membrane inhibited epidural fibrosis and peridural adhesions.

In a different approach, Yang et al. ${ }^{[96]}$ took advantage of the similarities between the mechanical properties of $\mathrm{BC}$ and brain tissue, to produce a biocompatible neural interface. They developed electrodes by electron beam evaporation of gold in a BC substrate. These electrodes exhibited lower bending stiffness than Au-polyamide electrodes, high durability and ability to record brain electric activity, demonstrating its potential to treat neurological disorders.

2.2.6. Artificial cornea and retina 
Retinal pigment epithelium (RPE) consists of a monolayer of pigmented and polygonalshaped epithelial cells, which carry out several essential tasks for visual function. ${ }^{[97]}$ The most common cause of blindness worldwide is the age-related macular degeneration, which is related to the degeneration of the retina. ${ }^{[98]}$ The replacement of unhealthy RPE by healthy stem cell-derived RPE-like cells, transplanted as a single epithelial sheet on a carrier substrate has shown to be a promising therapy. ${ }^{[99]}$ The requirements of an ideal carrier for RPE transplantation are very complex, therefore the development of viable substrates has not yet been successful. Gonçalves et al. ${ }^{[100]}$ developed an acetylated bacterial cellulose $(A B C)$ substrate coated with urinary bladder matrix (UBM) for the adhesion and proliferation of RPE cells. The prepared substrates allowed the development of a cell monolayer, phenotypically like natural RPE cells (polygonal shaped morphology and microvilli), able to express metabolic (RPE65) and cytoskeletal (ZO-1) essential proteins. The produced composite substrates also exhibited low swelling effect, high mechanical strength, and non-pyrogenicity. Altogether, these characteristics make ABC substrates promising cell carriers in RPE transplantation.

Another common cause of visual injury or blindness worldwide are the cornea opacities. ${ }^{[101]}$ The most widely used treatment for cornea opacities is corneal grafts. However, the xenografts currently applied exhibit rejection issues after 4 to 5 years of treatment, and allografts, besides originating the best results, have limited supply. ${ }^{[102]}$ Biopolymers are gaining more attention as potential materials for replacement of corneal tissue, by recovering the proper refractive status of the eye. Due to its properties, BC is a potential candidate for cornea replacement. However, BC exhibits limited transparency and is inelastic.

Aiming at improving its mechanical and optical properties, $\mathrm{BC}$ was combined with polycaprolactone (PCL), which is a biodegradable, bioabsorbable, biocompatible and viscoelastic polymer. The composites were prepared by impregnation of the PCL acetone solution into a dried BC membrane. The BC-PCL composite membranes showed to have improved transparency (transmittance of $85 \%$ ), be biocompatible, and more malleable. ${ }^{[103,104]}$ To further evaluate the potential clinical applications of these membranes, Sepúlveda et al.[105] implanted both BC and BC-PCL composite membranes in rabbits' cornea. Both BC and BC-PCL implants remained stable in corneal tissue and protected the ocular surface during the follow-up time (45 days). However, it was observed as a chronic inflammatory condition, incomplete epithelialization over the 
implanted membranes, and disorganized collagen fibers, indicating that any of the implants tested was unsuitable for the replacement of rabbits' corneal tissue.

\subsubsection{Soft Tissues}

Nowadays, prosthetic meshes are commonly used in abdominal wall hernia surgery, and this practice is known to reduce the rate of postoperative recurrence. Expanded polytetrafluorethylene (ePTFE) is among the synthetic prostheses used for this purpose; however, it shows some limitations, such as the lack of incorporation in the host tissues and seroma formation. ${ }^{[106]} \mathrm{BC}$ hydrogel was previously proved to be a suitable material to prevent postoperative peritoneal adhesions. However, its use as abdominal meshes is restricted by its gelloid properties.

Silveira et al. ${ }^{[67]}$ developed two distinct types of BC meshes, a compacted one and a perforated one, and compared them with ePTFE meshes in terms of their in vivo tissue response. The in vivo evaluation was done using Wistar rats by inducing an acute muscle aponeurotic effect. The results showed that perforated BC membranes exhibited an improved performance, explained by its effective integration in host tissue and tissue remodeling induction effect, as well as due to its suitable biomechanical properties. Lai et al. ${ }^{[107]}$ developed and evaluated a novel TEMPO-mediated modified bacterial cellulose (TBC) mesh to act as an anti-adhesion mesh for hernia repair. The TBC was laser perforated to originate isotropic, flat and stable structures, which avoided deformation under pressure. Comparatively to polypropylene mesh (the most widely used in these cases), the prepared mesh showed preferential adsorption of bovine serum albumin (BSA) and enhanced expression of collagen type I in fibroblasts. Furthermore, TBC mesh was found to cause less inflammation and to be surrounded by freshly formed connective tissue, constituted by collagen type I after implantation in rabbits for 1 week.

\subsubsection{Tympanic membrane}

Tympanic membrane (TM) perforations are a usual problem in otology and can be caused by physical external trauma or infection of the middle ear. ${ }^{[108]}$ The TM has high regeneration ability, often resulting in spontaneous healing of acute perforations. However, in some cases, TM perforations are not able to heal without surgical intervention. ${ }^{[109]}$ Myringoplasty is the reconstructive surgery for reparations of TM perforations. ${ }^{[110]}$ Temporalis fascia is probably the most used tissue for myringoplasty, however, its use shows some drawbacks. ${ }^{[111]}$ Thus, $\mathrm{BC}$ has been emerging as a promising 
material to replace temporalis fascia in this kind of intervention. This calls for a deep investigation of the effects of its application in humans ${ }^{[112]}$ and a comparison to the use of the "standard" material, temporalis fascia. [113]

Biskin et al.[112] analyzed the clinical records of 12 patients (16 ears) who underwent myringoplasty using $\mathrm{BC}$ and observed that $\mathrm{BC}$ grafts did not induce any complication, such as granulation tissue formation or infection in any patient. Furthermore, they concluded that $\mathrm{BC}$ graft material led to a high success rate in small TM perforations, and was a safe, inexpensive and easy to use.

In this previous study, $\mathrm{BC}$ was presented as a safe and biocompatible alternative to temporalis fascia, and then, the need for comparing both have arisen. To fill this gap, Silveira et al. ${ }^{[113]}$ performed a randomized clinical trial to compare $\mathrm{BC}$ and temporalis fascia grafts on the following parameters: time of epithelialization, surgical time, hospitalization costs and rate of closure of the TM perforation. The rate of TM perforation closure was analogous in both groups. Concerning the surgical time and hospitalization costs, BC showed to be superior to temporalis fascia (14.06 minutes and R\$ 600 of BC, against 76.50 minutes and $\mathrm{R} \$ 7778$ of temporalis fascia), indicating that $\mathrm{BC}$ can be a good graft material for myringoplasty.

Another already used autogenous graft in several surgeries, including myringoplasty, is fat. ${ }^{[14]}$ To compare BC, fat and temporalis fascia grafts, Mandour et al. ${ }^{[115]}$ performed a prospective randomized trial. Similarly, to the previously mentioned studies, this team found that $\mathrm{BC}$ exhibited shorter surgery times, and an improved hearing and healing, regarding temporalis fascia and fat grafts.

\subsubsection{Cartilage regeneration}

Cartilage is a connective tissue comprised mainly by chondrocytes and a highly complex ECM, which contains collagen, glycosaminoglycans, laminin, elastin, fibronectin, and water. This type of tissue is found in several parts of the body, namely in the joints, ear, trachea, intervertebral discs and ribs. Cartilage defects can have several distinct onsets, such as aging, developmental disorder, sports injuries, joint injury and can cause joint pain, and sometimes loss of mobility. As a result of its avascular nature and low mitotic activity, cartilage exhibits a poor regenerative ability. Nowadays, cartilage defects are treated with autogenous cartilage grafts and prostheses. However, as it is well-known, 
these present several drawbacks. ${ }^{[116,117]}$ Thus, BC and its composites have been widely studied as a material for tissue engineered scaffolds.

Akaraonye et al. ${ }^{[118]}$ developed a BC-poly(3-hydroxybutyrate) $(\mathrm{P}(3 \mathrm{HB})$ ) 3D composite scaffold, using sucrose as a porogen, with good dispersion and strong adhesion between $\mathrm{BC}$ and $\mathrm{P}(3 \mathrm{HB})$. The resulting 3D scaffold exhibited improved load-bearing properties, high surface area-to-volume ratio, regular distribution of pore diameter and morphological resemblances with ECM. The high porosity of the scaffolds culminated in the infiltration and migration of mouse chondrogenic ATDC5 cells deep into the scaffold material. Furthermore, it was found an enhanced cell attachment and proliferation, as well as the maintenance of the chondrocyte phenotype.

Using a different approach, Horbert et al.[119] developed BC implants by 3D laser perforation and studied the regenerative capacity of the implants loaded with cells and free in a standardized bovine cartilage punch model. The 3D perforation allowed the ingrowth and movement of chondrocytes through the implant network, which helped the long-term performance of the implant. The cell-loading improved its performance by quickening cell colonization. The gradual increase of cell seeding, matrix deposition, and chondrogenic differentiation suggested the beginning of cartilage regeneration.

Taking advantage of the mechanical properties and structural similarity between BC and ECM, Wang et al. ${ }^{[120]}$ designed ECM-mimicking microcarriers ( 

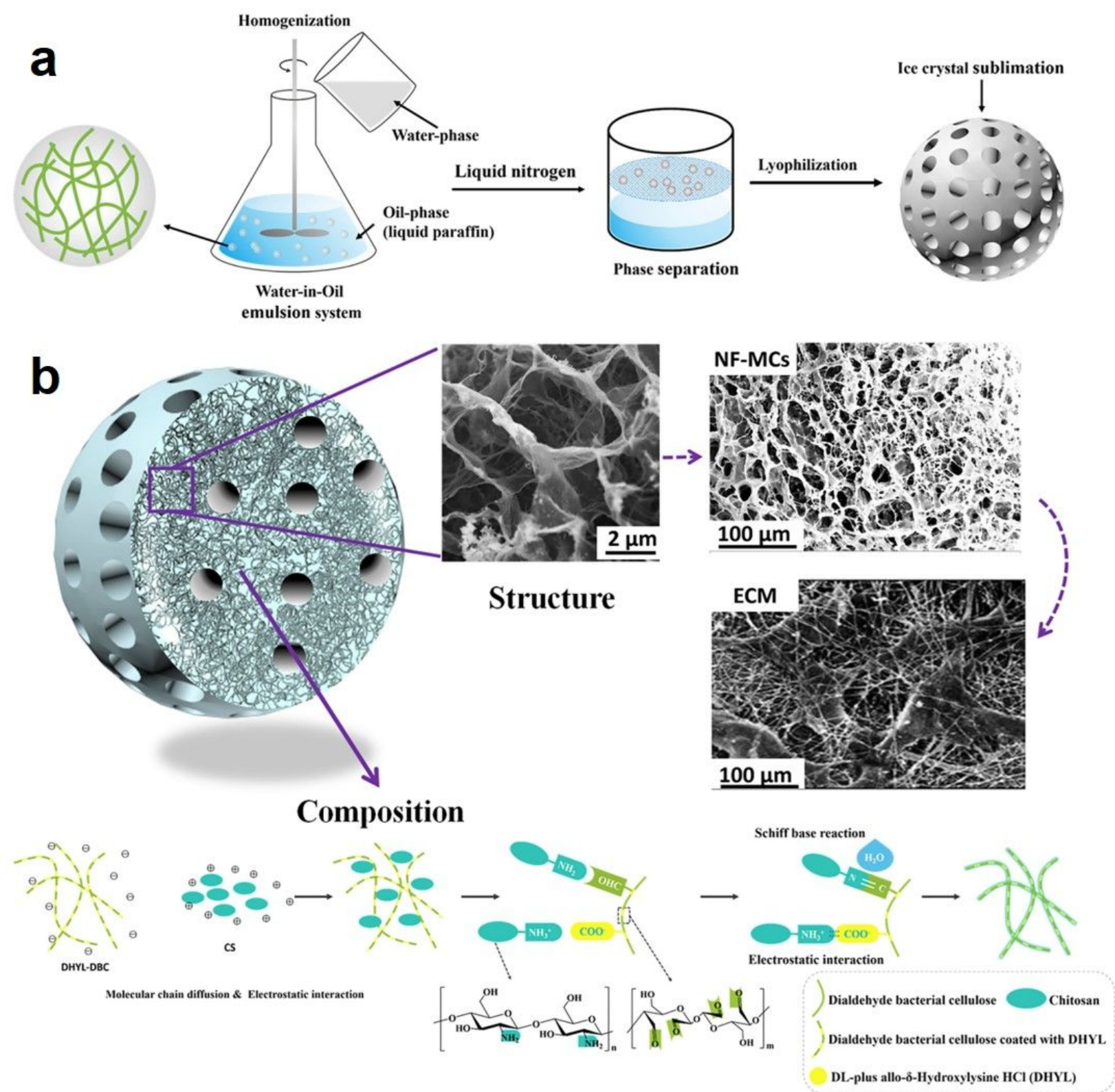

Figure 3). They also incorporated hydroxylysine (DHYL), which is an important collagen type II component, chitosan, and hyaluronic acid. The nanofibrous microcarriers (NFMCs) were cultured with bone marrow-derived mesenchymal stem cells (BMSCs) in a rotary cell culture system for 21 days to form the cartilage microtissues. With this innovative approach, they achieved a fine-tuning of porosity, pore size, mechanical properties, fiber diameter, and bioabsorption of NF-MCs. The NF-MCs showed a good ability for cell proliferation and differentiation. The prepared cartilage microtissues were implanted into a critical-size knee articular cartilage defect in mice and exhibited a good ability on the repair of cartilage tissue. 
Wu et al. ${ }^{[121]}$ incorporated lotus root starch in situ into BC to improve its biocompatibility. At the same time, spherical agarose particles were used to create a homogeneous porous network. Finally, through mineralization, spherical hydroxyapatite (HA) crystals were formed on the scaffold surface. The prepared composite scaffold enabled an improved proliferation of chondrocytes and higher total cell number. Moreover, the interconnected porous architecture of the scaffold enables efficient cell penetration, culminating in a good 3D cell distribution.

Zhu et al. ${ }^{[122]}$ developed a double network structure prepared by 1-ethyl-3-(3-(dimethylamino)propyl) carbodiimide hydrochloride (EDC) and N-hydroxy succinimide (NHS) mediated lysine cross-linking of poly( $\gamma$-glutamic acid) (PGA) and sodium alginate ionically cross-linked (Figure 4). To improve the mechanical properties of this double-network structure, they incorporated BC. Moreover, the authors designed a bilayer structure: a nonporous top layer and a porous bottom layer, which intended to mimic osteochondral tissues. Finally, HA microparticles were introduced in the top layer to stimulate cartilage matrix deposition, and HA nanocrystals in the bottom layer to stimulate osteogenesis and compression modulus. This composite scaffold presented a compression modulus similar to that of native articular cartilage and the swelling behavior was suitable for application in osteochondral tissue regeneration. Furthermore, the prepared scaffold exhibited good repair ability in osteochondral defect model of rabbits.

Another example that highlights the efforts made to combine the advantageous properties of $\mathrm{BC}$ and HA is the work developed by Kumbhar et al. ${ }^{[123]}$. In this work, they prepared a bilayer composite comprised of two BC composites: BC-HA and BC-glycosaminoglycans. In vitro assays with osteoblasts and human articular chondrocytes evidenced that the developed scaffolds could support cell attachment and proliferation. Furthermore, the in vivo tests were performed through implantation of the prepared scaffolds in osteochondral defects created in rat knees. These experiments indicated that the scaffolds allowed tissue ingrowth, accelerated the regeneration of articular cartilage and subchondral bone, as well as induced no immunological or inflammation reactions. Moreover, micro-computed tomography results evidenced that the ratio of bone volume-to-tissue volume and bone mineral density were significantly increased in the rats that received the scaffolds relatively to the control ones. 
In a distinct study, Yang et al. ${ }^{[124]}$ developed a new strategy for the preparation of 3D structures mimicking intervertebral discs (
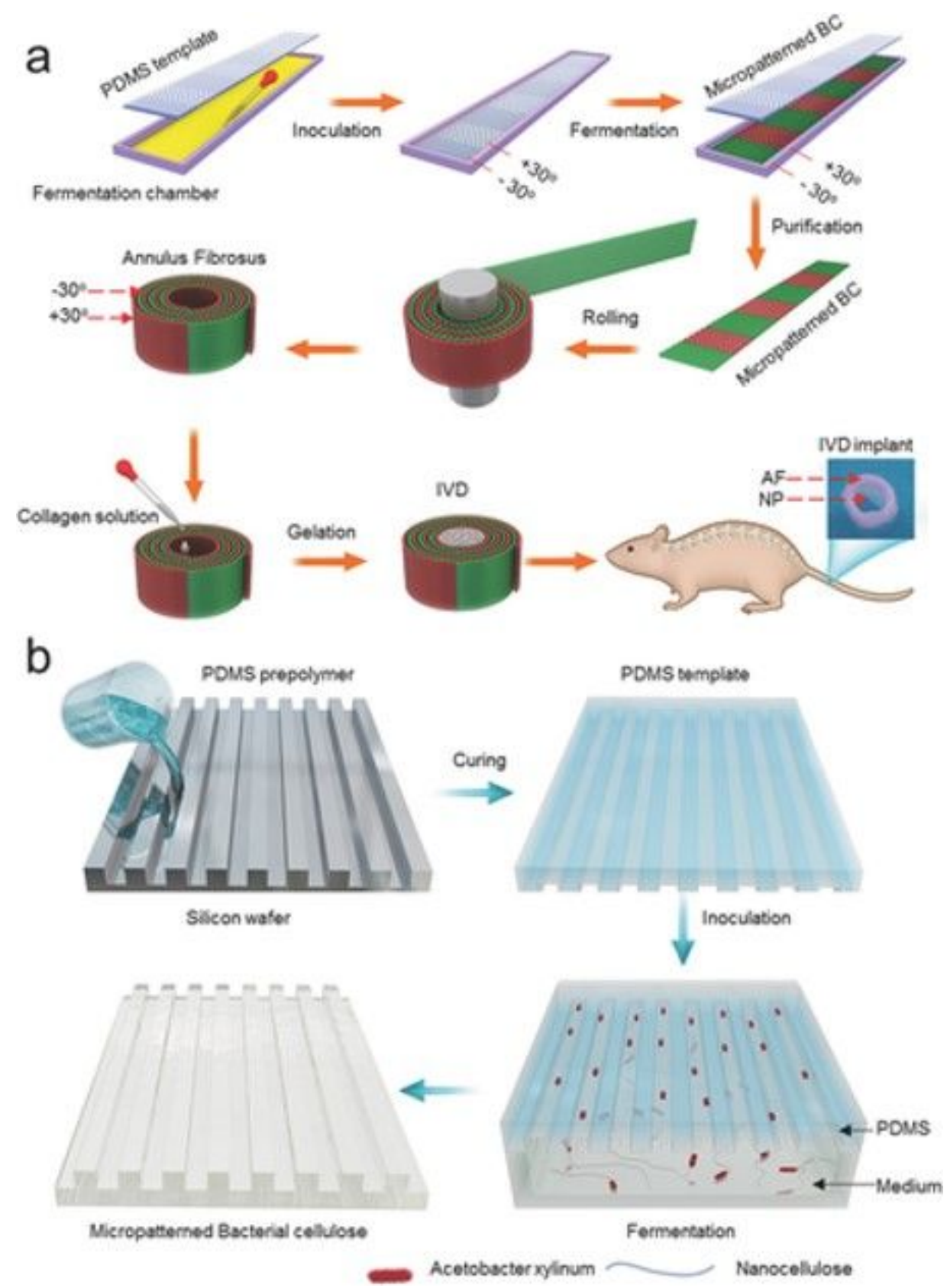

Figure 5). This strategy involved the cultivation of Acetobacter xylinum in a micropatterned polydimethylsiloxane (PDMS) template. This micropatterned BC membrane was then rolled to form the annulus fibrous part of the intervertebral disk. Subsequently, the core of the rolled BC membrane was filled with a collagen solution to mimic, after gelation, the nucleus pulposus. The in vitro studies indicated good biocompatibility of the composites. Furthermore, in vivo tests on rats demonstrated that 
the implant developed presents excellent shape maintenance, tissue integration, hydration, flexibility, and mechanical support, creating a segment able to move.

\subsubsection{Bone regeneration}

Clinical conditions, such as tumors, trauma, and diseases (osteitis and osteomyelitis) have highlighted the importance of bone regeneration. Tissue engineering has been a highly studied alternative to conventional therapeutics, such as autografts, xenografts, and allografts. ${ }^{[15]}$ As a result of its physicochemical properties, several $\mathrm{BC}$ composites and strategies using this type of material have been studied.

One of the materials intensively studied for conjugation with $\mathrm{BC}$ was HA. HA $\left[\mathrm{Ca}_{10}\left(\mathrm{PO}_{4}\right)_{6}(\mathrm{OH})_{2}\right]$, is the main non-organic component of bone. ${ }^{[125]} \mathrm{HA}$ exhibits a chemical and crystallographic structure analogous to the one of the bone and has been exhaustively studied for bone regeneration purposes. Moreover, HA has been known by its bioabsorbability, biocompatibility, bone-bonding ability, good osteoconductivity and bone mimicking crystalline structure. ${ }^{[15]}$ Examples of the research done in the last years encompassing $\mathrm{BC}$ and $\mathrm{HA}$ are listed in Table 3. A specific example is a work developed by $\mathrm{Hu}$ et al. ${ }^{[126]}$ where they prepared a bioabsorbable BC-HA composite through the immersion of BC membrane in an HA solution prepared in saturated synthetic body fluid (SBF) (1.0x) instead of oversaturated SBF (1.5x). This modification to the common procedure made it easier and proved to improve the total amount of calcium phosphates bounded to BC. The bioabsorbability was conferred by the incorporation of cellulosic enzymes, and in vitro bioabsorbability assays exhibited $96 \%$ of glucose release, indicating an almost complete degradation of the scaffold. Furthermore, the scaffold prepared in saturated SBF exhibited improved biocompatibility than the scaffold prepared using oversaturated SBF.

As a result of its 3D structure that mimics the ECM, BC can also be used as a template for the formation of inorganic scaffolds. ${ }^{[127-133]}$ Although, this topic is not the main focus of this review, for a better comprehension of this thematic we suggest the reading of the work developed by Salama. ${ }^{[134]}$ Other examples of BC composites, new processing methodologies and in vitro and in vivo studies, aiming at contributing to enhancing bone regeneration are presented in Table 4. 


\section{Conclusions}

The interest in using $\mathrm{BC}$ in the design and development of materials for biomedical applications has increasingly grown over the past years. Although BC is not naturally bioabsorbable, it has many other characteristics of interest that are mandatory for the development of this kind of products, being these characteristics mainly its biocompatibility, low cytotoxicity, very high water holding capacity and superior mechanical properties. By chemical modification or simple conjugation with other materials, $\mathrm{BC}$ characteristics can be further improved to meet the proper demands of the applications of interest. These applications can be the development of wound dressing and healing patches, design of drug (and other molecules) delivery systems, and the preparation of implants and grafts for very different parts of the organism. Over this review, $\mathrm{BC}$ has shown to be a material from which better and more efficient materials can be produced, in some cases, comparing to ones in the market, in other cases, better than previous "versions" of $\mathrm{BC}$-based materials. As a result of $\mathrm{BC}$ versatility and customization, in the years to come, with the surge of new technology, $\mathrm{BC}$ will be more relevant in the biomedical area. New and cost-effective drug delivery systems will be developed. BC-based patches, scaffolds, and grafts for both internal and external use, for wound healing, tissue engineering, and regenerative medicine, will be refined to better meet the needs of each application, whereas there will be always the challenge of modifying $\mathrm{BC}$ without losing its properties of interest.

\section{Acknowledgement}

Tiago Carvalho acknowledges Fundação para a Ciência e a Tecnologia (FCT), for the PhD grant SFRH/BD/130458/2017. F. L. Sousa acknowledges FCT for the researcher contract IF/00222/2015. Prof. H. A. Santos acknowledges financial support from the HiLIFE Research Funds and the Sigrid Jusélius Foundation.

\section{Conflict of interest}

The authors declare no conflict of interest. 


\section{References}

[1] J. M. Rajwade, K. M. Paknikar, J. V. Kumbhar, Appl. Microbiol. Biotechnol. 2015, 99, 2491.

[2] H. G. de Oliveira Barud, R. R. da Silva, H. da Silva Barud, A. Tercjak, J. Gutierrez, W. R. Lustri, O. B. de Oliveira, S. J. L. Ribeiro, Carbohydr. Polym. 2016, 153, 406.

[3] R. J. Moon, A. Martini, J. Nairn, J. Simonsen, J. Youngblood, Chem. Soc. Rev. 2011, 40, 3941.

[4] D. Klemm, B. Heublein, H. P. Fink, A. Bohn, Angew. Chemie - Int. Ed. 2005, 44, 3358.

[5] I. M. Saxena, R. M. Brown, Ann. Bot. 2005, 96, 9.

[6] M. Moniri, A. Boroumand Moghaddam, S. Azizi, R. Abdul Rahim, A. Bin Ariff, W. Zuhainis Saad, M. Navaderi, R. Mohamad, Nanomaterials 2017, 7, 257.

[7] M. Velásquez-Riaño, V. Bojacá, Cellulose 2017, 24, 2677.

[8] E. F. Douglass, H. Avci, R. Boy, O. J. Rojas, R. Kotek, Polym. Rev. 2018, 58, 102.

[9] I. Reiniati, A. N. Hrymak, A. Margaritis, Crit. Rev. Biotechnol. 2017, 37, 510.

[10] H. Ullah, F. Wahid, H. A. Santos, T. Khan, Carbohydr. Polym. 2016, 150, 330.

[11] C. Campano, A. Balea, A. Blanco, C. Negro, Cellulose 2016, 23, 57.

[12] G. F. Picheth, C. L. Pirich, M. R. Sierakowski, M. A. Woehl, C. N. Sakakibara, C. F. de Souza, A. A. Martin, R. da Silva, R. A. de Freitas, Int. J. Biol. Macromol. 2017, 104, 97.

[13] A. R. White, M. Benziman, R. M. Brown, C. H. Haigler, K. M. Cooper, Proc. Natl. Acad. Sci. 2006, 77, 6678.

[14] A. F. Jozala, L. C. de Lencastre-Novaes, A. M. Lopes, V. de Carvalho SantosEbinuma, P. G. Mazzola, A. Pessoa-Jr, D. Grotto, M. Gerenutti, M. V. Chaud, Appl. Microbiol. Biotechnol. 2016, 100, 2063.

[15] S. Torgbo, P. Sukyai, Appl. Mater. Today 2018, 11, 34.

[16] D. Klemm, E. D. Cranston, D. Fischer, M. Gama, S. A. Kedzior, D. Kralisch, F. Kramer, T. Kondo, T. Lindström, S. Nietzsche, K. Petzold-Welcke, F. Rauchfuß, Mater. Today 2018, 21, 720.

[17] J. Yu, T.-R. Huang, Z. H. Lim, R. Luo, R. R. Pasula, L.-D. Liao, S. Lim, C.-H. Chen, Adv. Healthc. Mater. 2016, 5, 2983.

[18] T. Hoshi, K. Yamazaki, Y. Sato, T. Shida, T. Aoyagi, Heliyon 2018, 4, e00873.

[19] M. Schaffner, P. A. Rühs, F. Coulter, S. Kilcher, A. R. Studart, Sci. Adv. 2017, 3, eaao6804.

[20] N. Petersen, P. Gatenholm, Appl. Microbiol. Biotechnol. 2011, 91, 1277.

[21] F. Torres, S. Commeaux, O. Troncoso, J. Funct. Biomater. 2012, 3, 864.

[22] I. Sulaeva, U. Henniges, T. Rosenau, A. Potthast, Biotechnol. Adv. 2015, 33, 1547.

[23] M. Singh, A. R. Ray, P. Vasudevan K. Verma, S. K. Guha, Biomater. Med. Devices. Artif. Organs 1979, 7, 495.

[24] S. Laurence, R. Bareille, C. Baquey, J. C. Fricain, J. Biomed. Mater. Res. - Part A 2005, 73, 422.

[25] Y. Hu, J. M. Catchmark, Acta Biomater. 2011, 7, 2835.

[26] Y. Hu, J. M. Catchmark, J. Biomed. Mater. Res. - Part B Appl. Biomater. 2011, 97 $B, 114$.

[27] T. R. Stumpf, X. Yang, J. Zhang, X. Cao, Mater. Sci. Eng. C 2018, 82, 372.

[28] M. L. Cacicedo, M. C. Castro, I. Servetas, L. Bosnea, K. Boura, P. Tsafrakidou, A. Dima, A. Terpou, A. Koutinas, G. R. Castro, Bioresour. Technol. 2016, 213, 172.

[29] H. Luo, G. Xiong, Y. Huang, F. He, Y. Wang, Y. Wan, Mater. Chem. Phys. 2008, 
$110,193$.

[30] D. O. S. Recouvreux, R. V. Antônio, A. K. Pitlovanciv, C. R. Rambo, L. M. Porto, C. A. Carminatti, Mater. Sci. Eng. C 2007, 28, 549.

[31] O. Saibuatong, M. Phisalaphong, Carbohydr. Polym. 2010, 79, 455.

[32] E. M. Feldmann, J. F. Sundberg, B. Bobbili, S. Schwarz, P. Gatenholm, N. Rotter, J. Biomater. Appl. 2013, 28, 626.

[33] L. Nimeskern, H. Martínez Ávila, J. Sundberg, P. Gatenholm, R. Müller, K. S. Stok, J. Mech. Behav. Biomed. Mater. 2013, 22, 12.

[34] H. Bäckdahl, M. Esguerra, D. Delbro, B. Risberg, P. Gatenholm, J. Tissue Eng. Regen. Med. 2008, 2, 320.

[35] R. M. Ribeiro-Viana, P. C. S. Faria-Tischer, C. A. Tischer, Carbohydr. Polym. 2016, 148, 21.

[36] B. F. Liu, G. Wang, X. F. Chen, G. Yang, X. D. Shi, L. J. Yu, Adv. Mater. Res. 2009, 47-50, 1359.

[37] T. Kondo, M. Nojiri, Y. Hishikawa, E. Togawa, D. Romanovicz, R. M. Brown, Proc. Natl. Acad. Sci. 2002, 99, 14008.

[38] M. B. Sano, A. D. Rojas, P. Gatenholm, R. V. Davalos, Ann. Biomed. Eng. 2010, $38,2475$.

[39] H. Ullah, H. A. Santos, T. Khan, Cellulose 2016, 23, 2291.

[40] S. Saska, H. S. Barud, A. M. M. Gaspar, R. Marchetto, S. J. L. Ribeiro, Y. Messaddeq, Int. J. Biomater. 2011, 2011, 1.

[41] H. Ullah, M. Badshah, E. Mäkilä, J. Salonen, M.-A. Shahbazi, H. A. Santos, T. Khan, Cellulose 2017, 24, 1445.

[42] N. Ahmad, M. C. I. Mohd Amin, I. Ismail, F. Buang, Expert Opin. Drug Deliv. 2016, 13, 621 .

[43] W. Shao, H. Liu, S. Wang, J. Wu, M. Huang, H. Min, X. Liu, Carbohydr. Polym. 2016, 145, 114.

[44] C. Subtaweesin, W. Woraharn, S. Taokaew, N. Chiaoprakobkij, A. Sereemaspun, M. Phisalaphong, Appl. Sci. 2018, 8, 1188.

[45] S. Sukhtezari, H. Almasi, S. Pirsa, M. Zandi, M. Pirouzifard, Carbohydr. Polym. 2017, 156, 340 .

[46] L. Saïdi, C. Vilela, H. Oliveira, A. J. D. Silvestre, C. S. R. Freire, Carbohydr. Polym. 2017, 169, 357.

[47] C. Siangsanoh, S. Ummartyotin, K. Sathirakul, P. Rojanapanthu, W. Treesuppharat, J. Mol. Liq. 2018, 256, 90.

[48] C. Chen, X. Chen, H. Zhang, Q. Zhang, L. Wang, C. Li, B. Dai, J. Yang, J. Liu, D. Sun, Acta Biomater. 2017, 55, 434.

[49] M. Badshah, H. Ullah, S. A. Khan, J. K. Park, T. Khan, Cellulose 2017, 24, 5041.

[50] M. L. Cacicedo, G. A. Islan, M. F. Drachemberg, V. A. Alvarez, L. C. Bartel, A. D. Bolzán, G. R. Castro, New J. Chem. 2018, 42, 7457.

[51] E. S. Morais, N. H. C. S. Silva, T. E. Sintra, S. A. O. Santos, B. M. Neves, I. F. Almeida, P. C. Costa, I. Correia-Sá, S. P. M. Ventura, A. J. D. Silvestre, M. G. Freire, C. S. R. Freire, Carbohydr. Polym. 2019, 206, 187.

[52] M. Badshah, H. Ullah, A. R. Khan, S. Khan, J. K. Park, T. Khan, Int. J. Biol. Macromol. 2018, 113, 526.

[53] S. Ye, L. Jiang, J. Wu, C. Su, C. Huang, X. Liu, W. Shao, ACS Appl. Mater. Interfaces 2018, 10, 5862.

[54] S. Springer, M. Zieger, U. C. Hipler, J. Lademann, V. Albrecht, R. Bueckle, C. Meß, M. Kaatz, V. Huck, Ski. Res. Technol. 2019, 25, 68.

[55] Y. Qiu, L. Qiu, J. Cui, Q. Wei, Mater. Sci. Eng. C 2016, 59, 303. 
[56] S. Napavichayanun, R. Yamdech, P. Aramwit, Arch. Dermatol. Res. 2016, 308, 123.

[57] A. Khalid, H. Ullah, M. Ul-Islam, R. Khan, S. Khan, F. Ahmad, T. Khan, F. Wahid, RSC Adv. 2017, 7, 47662.

[58] A. Khalid, R. Khan, M. Ul-Islam, T. Khan, F. Wahid, Carbohydr. Polym. 2017, $164,214$.

[59] S.-P. Lin, H.-N. Kung, Y.-S. Tsai, T.-N. Tseng, K.-D. Hsu, K.-C. Cheng, Cellulose 2017, 24, 4927.

[60] P. R. F. de S. Moraes, S. Saska, H. Barud, L. R. de Lima, V. da C. A. Martins, A. M. de G. Plepis, S. J. L. Ribeiro, A. M. M. Gaspar, Mater. Res. 2016, 19, 106.

[61] E. Y. X. Loh, N. Mohamad, M. B. Fauzi, M. H. Ng, S. F. Ng, M. C. I. Mohd Amin, Sci. Rep. 2018, 8, 2875.

[62] Z. Karahaliloğlu, M. Demirbilek, İ. Ulusoy, B. Gümüşkaya, E. Baki Denkbaş, $J$. Appl. Polym. Sci. 2016, 133, 1.

[63] Z. Karahaliloğlu, M. Demirbilek, İ. Ulusoy, B. Gümüşkaya, E. B. Denkbaş, $J$. Biomed. Mater. Res. Part B Appl. Biomater. 2017, 105, 1573.

[64] M. Jin, W. Chen, Z. Li, Y. Zhang, M. Zhang, S. Chen, Cellulose 2018, 25, 6705.

[65] S. Napavichayanun, S. Ampawong, T. Harnsilpong, A. Angspatt, P. Aramwit, Arch. Dermatol. Res. 2018, 310, 795.

[66] P. Pourali, N. Razavianzadeh, L. Khojasteh, B. Yahyaei, J. Mater. Sci. Mater. Med. 2018, 29, 90 .

[67] R. K. Silveira, A. R. B. Coelho, F. C. M. Pinto, A. V. de Albuquerque, D. A. de Melo Filho, J. L. de Andrade Aguiar, J. Mater. Sci. Mater. Med. 2016, 27, 129.

[68] Z. Keskin, A. Sendemir Urkmez, E. E. Hames, Mater. Sci. Eng. C 2017, 75, 1144.

[69] S.-H. Jun, S.-H. Lee, S. Kim, S.-G. Park, C.-K. Lee, N.-K. Kang, Cellulose 2017, $24,5267$.

[70] A. F. Leitão, M. A. Faria, A. M. R. Faustino, R. Moreira, P. Mela, L. Loureiro, I. Silva, M. Gama, Macromol. Biosci. 2016, 16, 139.

[71] X. Li, J. Tang, L. Bao, L. Chen, F. F. Hong, Carbohydr. Polym. 2017, 178, 394.

[72] C. Weber, S. Reinhardt, K. Eghbalzadeh, M. Wacker, M. Guschlbauer, A. Maul, A. Sterner-Kock, T. Wahlers, J. Wippermann, M. Scherner, J. Vasc. Surg. 2018, $68,177 \mathrm{~S}$.

[73] Y. Li, K. Jiang, J. Feng, J. Liu, R. Huang, Z. Chen, J. Yang, Z. Dai, Y. Chen, N. Wang, W. Zhang, W. Zheng, G. Yang, X. Jiang, Adv. Healthc. Mater. 2017, 6, 1601343.

[74] A. F. Leitão, M. A. Faria, A. M. R. Faustino, R. Moreira, P. Mela, L. Loureiro, I. Silva, M. Gama, Macromol. Biosci. 2016, 16, 139.

[75] S. L. Arias, A. Shetty, J. Devorkin, J.-P. Allain, Acta Biomater. 2018, 77, 172.

[76] M. Kołaczkowska, P. Siondalski, M. M. Kowalik, R. Pęksa, A. Długa, W. Zając, P. Dederko, I. Kołodziejska, E. Malinowska-Pańczyk, I. Sinkiewicz, H. Staroszczyk, A. Śliwińska, A. Stanisławska, M. Szkodo, P. Pałczyńska, G. Jabłoński, A. Borman, P. Wilczek, Mater. Sci. Eng. C 2019, 97, 302.

[77] B. Wang, X. Lv, S. Chen, Z. Li, J. Yao, X. Peng, C. Feng, Y. Xu, H. Wang, Cellulose 2017, 24, 5013.

[78] P. Weyell, U. Beekmann, C. Küpper, M. Dederichs, J. Thamm, D. Fischer, D. Kralisch, Carbohydr. Polym. 2019, 207, 1.

[79] S. I. Jinga, G. Voicu, A. Stoica-Guzun, M. Stroescu, A. M. Grumezescu, C. Bleotu, Dig. J. Nanomater. Biostructures 2014, 9, 543.

[80] G. Voicu, S. I. Jinga, B. G. Drosu, C. Busuioc, Carbohydr. Polym. 2017, 174, 160.

[81] M. Petelin, Z. Pavlica, U. Batista, D. Štiblar-Martinčič, U. Skalerič, Acta Vet. Hung. 
2004, 52, 33.

[82] M. Kadkhodazadeh, Z. Baghani, M. Torshabi, J. Oral Maxillofac. Res. 2017, 8, 1.

[83] D. Eberli, L. F. Filho, A. Atala, J. J. Yoo, Methods 2009, 47, 109.

[84] S. V. C. Lima, M. R. Machado, F. C. M. Pinto, M. M. de M. Lira, A. V. de Albuquerque, E. S. Lustosa, J. G. M. da Silva, O. Campos, Int. Braz J Urol 2017, $43,335$.

[85] G. T. da S. Maia, A. V. de Albuquerque, E. D. Martins Filho, F. T. de Lira Neto, V. S. B. de Souza, A. A. da Silva, M. M. de M. Lira, S. V. C. Lima, Acta Cir. Bras. 2018, 33, 673.

[86] H. Bäckdahl, G. Helenius, A. Bodin, U. Nannmark, B. R. Johansson, B. Risberg, P. Gatenholm, Biomaterials 2006, 27, 2141.

[87] X. Lv, J. Yang, C. Feng, Z. Li, S. Chen, M. Xie, J. Huang, H. Li, H. Wang, Y. Xu, ACS Biomater. Sci. Eng. 2016, 2, 19.

[88] X. G. Lv, C. Feng, Y. D. Liu, X. F. Peng, S. Y. Chen, D. D. Xiao, H. P. Wang, Z. Li, Y. M. Xu, M. J. Lu, Theranostics 2018, 8, 3153.

[89] W. Zhu, C. O’Brien, J. R. O’Brien, L. G. Zhang, Nanomedicine 2014, 9, 859.

[90] Y. Li, Y. Xiao, C. Liu, Chem. Rev. 2017, 117, 4376.

[91] N. Geisel, J. Clasohm, X. Shi, L. Lamboni, J. Yang, K. Mattern, G. Yang, K.-H. Schäfer, M. Saumer, Small 2016, 12, 5407.

[92] E. Altun, M. O. Aydogdu, S. O. Togay, A. Z. Sengil, N. Ekren, M. E. Haskoylu, E. T. Oner, N. A. Altuncu, G. Ozturk, M. Crabbe-Mann, J. Ahmed, O. Gunduz, M. Edirisinghe, Eur. Polym. J. 2019, 114, 98.

[93] D. Kim, S. Park, I. Jo, S.-M. Kim, D. H. Kang, S.-P. Cho, J. B. Park, B. H. Hong, M.-H. Yoon, Small 2017, 13, 1700331.

[94] Y. Hou, X. Wang, J. Yang, R. Zhu, Z. Zhang, Y. Li, J. Biomed. Mater. Res. Part A 2018, 106, 1288.

[95] B. Wang, P. Li, L. Shangguan, J. Ma, K. Mao, Q. Zhang, Y. Wang, Z. Liu, K. Mao, Int. J. Nanomedicine 2018, 13, 5257.

[96] J. Yang, M. Du, L. Wang, S. Li, G. Wang, X. Yang, L. Zhang, Y. Fang, W. Zheng, G. Yang, X. Jiang, ACS Appl. Mater. Interfaces 2018, 10, 33049.

[97] O. Strauss, Physiol. Rev. 2005, 85, 845.

[98] P. Mitchell, G. Liew, B. Gopinath, T. Y. Wong, Lancet 2018, 392, 1147.

[99] A. J. F. Carr, M. J. K. Smart, C. M. Ramsden, M. B. Powner, L. da Cruz, P. J. Coffey, Trends Neurosci. 2013, 36, 385.

[100] S. Gonçalves, I. P. Rodrigues, J. Padrão, J. P. Silva, V. Sencadas, S. LancerosMendez, H. Girão, F. M. Gama, F. Dourado, L. R. Rodrigues, Colloids Surfaces B Biointerfaces 2016, 139, 1.

[101] G. A. Stevens, R. A. White, S. R. Flaxman, H. Price, J. B. Jonas, J. Keeffe, J. Leasher, K. Naidoo, K. Pesudovs, S. Resnikoff, H. Taylor, R. R. A. Bourne, Ophthalmology 2013, 120, 2377.

[102] B. M. Pressler, Vet. Clin. North Am. - Small Anim. Pract. 2010, 40, 495.

[103] B. Grobelski, R. A. Wach, A. Adamus, A. K. Olejnik, K. Kowalska-Ludwicka, M. Kolodziejczyk, S. Bielecki, J. M. Rosiak, Z. Pasieka, Int. J. Polym. Mater. Polym. Biomater. 2014, 63, 518.

[104] H. S. Barud, S. J. L. Ribeiro, C. L. P. Carone, R. Ligabue, S. Einloft, P. V. S. Queiroz, A. P. B. Borges, V. D. Jahno, Polímeros 2013, 23, 135.

[105] R. V. Sepúlveda, F. L. Valente, E. C. C. Reis, F. R. Araújo, R. B. Eleotério, P. V. S. Queiroz, A. P. B. Borges, Pesqui. Vet. Bras. 2016, 36, 986.

[106] S. Bachman, B. Ramshaw, Surg. Clin. North Am. 2008, 88, 101.

[107] C. Lai, K. S. Hu, Q. L. Wang, L. Y. Sheng, S. J. Zhang, Y. Zhang, Starch - Stärke 
2018, 70, 1700319.

[108] Z. C. Lou, Z. H. Lou, Q. P. Zhang, Am. J. Otolaryngol. - Head Neck Med. Surg. 2012, 33, 549.

[109] F. Medical, A. State, W. Africa, 2008, 420.

[110] T. Palva, A. Palva, J. Käkjä, Ann. Otol. Rhinol. Laryngol. 1969, 78, 1074.

[111] S. Ayache, F. Braccini, F. Facon, J. M. Thomassin, Otol. Neurotol. 2003, 24, 158.

[112] S. Biskin, M. Damar, S. N. Oktem, E. Sakalli, D. Erdem, O. Pakir, Eur. Arch. OtoRhino-Laryngology 2016, 273, 3561.

[113] F. C. A. Silveira, F. C. M. Pinto, S. da S. Caldas Neto, M. de C. Leal, J. Cesário, J. L. de A. Aguiar, Braz. J. Otorhinolaryngol. 2016, 82, 203.

[114] J. C. Rindenberg, G. R. Mich, Laryngoscope 1978, 88, 982.

[115] Y. M. H. Mandour, S. Mohammed, M. o. A. Menem, Am. J. Otolaryngol. - Head Neck Med. Surg. 2019, 40, 168.

[116] J. Raghunath, J. Rollo, K. M. Sales, P. E. Butler, A. M. Seifalian, Biotechnol. Appl. Biochem. 2007, 46, 73.

[117] J. Raghunath, H. J. Salacinski, K. M. Sales, P. E. Butler, A. M. Seifalian, Curr. Opin. Biotechnol. 2005, 16, 503.

[118] E. Akaraonye, J. Filip, M. Safarikova, V. Salih, T. Keshavarz, J. C. Knowles, I. Roy, Polym. Int. 2016, 65, 780.

[119] V. Horbert, J. Boettcher, P. Foehr, F. Kramer, U. Udhardt, M. Bungartz, O. Brinkmann, R. H. Burgkart, D. O. Klemm, R. W. Kinne, Cellulose 2019, $26,647$.

[120] Y. Wang, X. Yuan, K. Yu, H. Meng, Y. Zheng, J. Peng, S. Lu, X. Liu, Y. Xie, K. Qiao, Biomaterials 2018, 171, 118.

[121] J. Wu, N. Yin, S. Chen, D. B. Weibel, H. Wang, Cellulose 2019, 26, 2513.

[122] X. Zhu, T. Chen, B. Feng, J. Weng, K. Duan, J. Wang, X. Lu, ACS Biomater. Sci. Eng. 2018, 4, 3534.

[123] J. Rajwade, D. Bodas, A. Barhanpurkar-Naik, J. Kumbhar, K. Paknikar, M. Wani, S. Jadhav, Int. J. Nanomedicine 2017, Volume 12, 6437.

[124] J. Yang, L. Wang, W. Zhang, Z. Sun, Y. Li, M. Yang, D. Zeng, B. Peng, W. Zheng, X. Jiang, G. Yang, Small 2018, 14, 1702582.

[125] S. V Dorozhkin, M. Epple, Angew. Chemie Int. Ed. 2002, 41, 3130.

[126] Y. Hu, Y. Zhu, X. Zhou, C. Ruan, H. Pan, J. M. Catchmark, J. Mater. Chem. B 2016, 4, 1235.

[127] C. Busuioc, M. Stroescu, A. Stoica-Guzun, G. Voicu, S. I. Jinga, Ceram. Int. 2016, $42,15449$.

[128] H. Luo, Y. Zhang, Z. Wang, Z. Yang, J. Tu, Z. Liu, F. Yao, G. Xiong, Y. Wan, Chem. Eng. J. 2017, 326, 210.

[129] H. Luo, W. Li, H. Ao, G. Li, J. Tu, G. Xiong, Y. Zhu, Y. Wan, Mater. Sci. Eng. C 2017, 76, 94.

[130] H. Luo, Y. Zhang, G. Li, J. Tu, Z. Yang, G. Xiong, Z. Wang, Y. Huang, Y. Wan, J. Biomater. Appl. 2017, 32, 265.

[131] C. Wen, Y. Hong, J. Wu, L. Luo, Y. Qiu, J. Ye, RSC Adv. 2018, 8, 14561.

[132] H. Luo, D. Ji, W. Li, J. Xiao, C. Li, G. Xiong, Y. Zhu, Y. Wan, Mater. Chem. Phys. 2016, $176,1$.

[133] H. Luo, Z. Zhou, G. Li, W. Li, Z. Li, G. Xiong, Y. Zhu, F. Yao, R. Guo, Y. Wan, J. Non. Cryst. Solids 2017, 457, 145.

[134] A. Salama, Int. J. Biol. Macromol. 2019, 127, 606.

[135] Y. Alkhatib, M. Dewaldt, S. Moritz, R. Nitzsche, D. Kralisch, D. Fischer, Eur. J. Pharm. Biopharm. 2017, 112, 164.

[136] G. Juncu, A. Stoica-Guzun, M. Stroescu, G. Isopencu, S. I. Jinga, Int. J. Pharm. 
2016, $510,485$.

[137] W. Treesuppharat, P. Rojanapanthu, C. Siangsanoh, H. Manuspiya, S. Ummartyotin, Biotechnol. Reports 2017, 15, 84.

[138] H. Luo, H. Ao, G. Li, W. Li, G. Xiong, Y. Zhu, Y. Wan, Curr. Appl. Phys. 2017, $17,249$.

[139] Y. Pötzinger, M. Rabel, H. Ahrem, J. Thamm, D. Klemm, D. Fischer, Cellulose 2018, 25, 1939.

[140] M. L. Cacicedo, I. E. León, J. S. Gonzalez, L. M. Porto, V. A. Alvarez, G. R. Castro, Colloids Surfaces B Biointerfaces 2016, 140, 421.

[141] P. Pourali, B. Yahyaei, 3 Biotech 2019, 9, 59.

[142] K. L. N. Kaminagakura, S. Sue Sato, P. Sugino, L. Kataki de Oliveira Veloso, D. C. dos Santos, C. R. Padovani, P. Basmaji, G. Olyveira, S. A. Schellini, J. Biomed. Mater. Res. Part B Appl. Biomater. 2019, 107, 724.

[143] S. Khan, M. Ul-Islam, M. Ikram, S. U. Islam, M. W. Ullah, M. Israr, J. H. Jang, S. Yoon, J. K. Park, Int. J. Biol. Macromol. 2018, 117, 1200.

[144] P. Brassolatti, H. W. Kido, P. S. Bossini, P. R. Gabbai-Armelin, A. N. Otterço, L. Almeida-Lopes, L. M. Zanardi, M. A. Napolitano, L. R. da S. de Avó, L. A. Forato, F. M. Araújo-Moreira, N. A. Parizotto, Biomed. Mater. Eng. 2017, 29, 29.

[145] M. Pandey, N. Mohamad, W.-L. Low, C. Martin, M. C. I. Mohd Amin, Drug Deliv. Transl. Res. 2017, 7, 89.

[146] S. Jiji, S. Udhayakumar, C. Rose, C. Muralidharan, K. Kadirvelu, Int. J. Biol. Macromol. 2019, 122, 452.

[147] W. Sajjad, T. Khan, M. Ul-Islam, R. Khan, Z. Hussain, A. Khalid, F. Wahid, Carbohydr. Polym. 2019, 206, 548.

[148] Y. Huang, J. Wang, F. Yang, Y. Shao, X. Zhang, K. Dai, Mater. Sci. Eng. C 2017, $75,1034$.

[149] J. Ran, P. Jiang, S. Liu, G. Sun, P. Yan, X. Shen, H. Tong, Mater. Sci. Eng. C 2017, $78,130$.

[150] P. M. Favi, S. P. Ospina, M. Kachole, M. Gao, L. Atehortua, T. J. Webster, Cellulose 2016, 23, 1263.

[151] S. Saska, L. N. Teixeira, L. M. S. de Castro Raucci, R. M. Scarel-Caminaga, L. P. Franchi, R. A. dos Santos, S. H. Santagneli, M. V. Capela, P. T. de Oliveira, C. S. Takahashi, A. M. M. Gaspar, Y. Messaddeq, S. J. L. Ribeiro, R. Marchetto, Int. J. Biol. Macromol. 2017, 103, 467.

[152] T. Q. Song, B. J. Ge, H. L. Chen, X. W. Yang, F. Yuan, Int. J. Clin. Exp. Pathol. 2016, 9, 9775 .

[153] P. Jiang, J. Ran, P. Yan, L. Zheng, X. Shen, H. Tong, J. Biomater. Sci. Polym. Ed. 2018, 29, 107.

[154] G. M. de Olyveira, P. Basmaji, L. M. M. Costa, M. L. dos Santos, C. dos Santos Riccardi, F. P. S. Guastaldi, R. M. Scarel-Caminaga, T. S. de Oliveira Capote, E. Pizoni, A. C. Guastaldi, Mater. Sci. Eng. C 2017, 75, 1359.

[155] P. Basu, N. Saha, P. Saha, Int. J. Polym. Mater. Polym. Biomater. 2019, 68, 134.

[156] H. Yan, X. Chen, M. Feng, Z. Shi, D. Zhang, Q. Lin, Mater. Lett. 2017, 209, 492.

[157] Y. Huang, J. Wang, F. Yang, Y. Shao, X. Zhang, K. Dai, Mater. Sci. Eng. C 2017, $75,1034$.

[158] J. M. Gutiérrez-Hernández, D. M. Escobar-García, A. Escalante, H. Flores, F. J. González, P. Gatenholm, G. Toriz, Mater. Sci. Eng. C 2017, 75, 445.

[159] S.-J. An, S.-H. Lee, J.-B. Huh, S. Jeong, J.-S. Park, H.-J. Gwon, E.-S. Kang, C.M. Jeong, Y.-M. Lim, Int. J. Mol. Sci. 2017, 18, 2236.

[160] S.-H. Lee, S.-J. An, Y.-M. Lim, J.-B. Huh, Materials (Basel). 2017, 10, 1018. 
[161] J. Chen, A. Zhuang, H. Shao, X. Hu, Y. Zhang, J. Mater. Chem. B 2017, 5, 3640.

[162] Y.-J. Lee, S.-J. An, E.-B. Bae, H.-J. Gwon, J.-S. Park, S. Jeong, Y.-C. Jeon, S.-H. Lee, Y.-M. Lim, J.-B. Huh, Materials (Basel). 2017, 10, 320.

[163] E. Vadaye Kheiry, K. Parivar, J. Baharara, B. S. Fazly Bazzaz, A. Iranbakhsh, Iran. J. Basic Med. Sci. 2018, 21, 965.

[164] M. de A. Silva, Y. K. de C. Leite, C. E. S. de Carvalho, M. L. T. Feitosa, M. M. de M. Alves, F. A. de A. Carvalho, B. C. V. Neto, M. A. Miglino, A. F. Jozala, M. A. M. de Carvalho, PeerJ 2018, 6, e4656.

[165] K. Dydak, A. Junka, P. Szymczyk, G. Chodaczek, M. Toporkiewicz, K. Fijałkowski, B. Dudek, M. Bartoszewicz, PLoS One 2018, 13, e0205205. 
Table 1. Summary of BC-based formulations for drug and other molecules delivery systems.

\begin{tabular}{|c|c|c|c|}
\hline Formulation & Cargo & Outcome & References \\
\hline BC incorporated with Poloxamers & Octenidine & Long-term drug release that lasted 8 days & [135] \\
\hline BC immersed in drug solution & Benzalconium chloride & Sustained release of the drug for at least $24 \mathrm{~h}$ & [40] \\
\hline $\begin{array}{l}\text { Drug or complex incorporated in } \\
\text { mono and multilayer BC films }\end{array}$ & $\begin{array}{l}\text { Scrophularia striata extract or a } \\
\text { complex also containing } \\
\beta \text {-cyclodextrin }\end{array}$ & $\begin{array}{l}\text { Films showed antioxidant activity. Addition of } \beta \text {-cyclodextrin controlled the } \\
\text { drug release. Lasting drug release was also observed in the multilayered films }\end{array}$ & [45] \\
\hline $\begin{array}{l}\text { Film of sodium carboxymethyl } \\
\text { cellulose reinforced with BC }\end{array}$ & Ibuprofen & Controlled drug release on higher contents of $\mathrm{BC}$ & [136] \\
\hline $\begin{array}{l}\text { BC soaked with the ionic liquids } \\
\text { and dried at room temperature in } \\
\text { a nitrogen atmosphere }\end{array}$ & Ionic liquids based on phenolic acids & $\begin{array}{l}\text { Sustained release through the human skin. High antioxidant and anti- } \\
\text { inflammatory activity. }\end{array}$ & {$[51]$} \\
\hline $\begin{array}{l}\text { BC-gelatin hydrogel prepared } \\
\text { through copolymerization and } \\
\text { loaded with drug }\end{array}$ & Methylene blue & $\begin{array}{l}\text { BC-gelatin hydrogel showed a more controlled drug release than gelatin } \\
\text { hydrogel }\end{array}$ & {$[137]$} \\
\hline $\begin{array}{l}\text { Surface modified BC with acetic } \\
\text { anhydride, and dried in different } \\
\text { fashions }\end{array}$ & Famotidine and tizanidine & $\begin{array}{l}\text { Different formulations showed different release ratios. Freeze-dried } \\
\text { formulations revealed better drug sustaining for the drug with lower solubility } \\
\text { in water }\end{array}$ & [52] \\
\hline $\begin{array}{l}\text { BC films modified with } \\
\text { methoxylated pectin }\end{array}$ & Albumin and Levofloxacin & Controlled release of both molecules. Levofloxacin cytotoxicity was reduced & {$[50]$} \\
\hline BC loaded with antibiotic & Tetracycline hydrochloride & $\begin{array}{l}\text { Display controlled release, after an initial burst release of the drug and } \\
\text { antibacterial activity }\end{array}$ & [43] \\
\hline $\begin{array}{l}\text { Drug-loaded } 12 \mathrm{~mm} \text { diameter } \mathrm{BC} \\
\text { tablets }\end{array}$ & Famotidine and tizanidine & Superior burst release drug delivery characteristics & [49] \\
\hline $\begin{array}{l}\text { Hollow BC spheres loaded with } \\
\text { the drug }\end{array}$ & Fluorescein isothiocyanate-dextran & Drug burst release & {$[18]$} \\
\hline $\begin{array}{l}\text { Capsule shells of pure BC or } \\
\text { conjugated with starch, } \\
\text { hydroxypropylmethylcellulose or } \\
\text { carboxymethyl cellulose }\end{array}$ & Salbutamol sulfate & $\begin{array}{l}\text { Burst release was observed on } \mathrm{BC} \text { only capsules. Other capsules showed } \\
\text { controlled release, and the ones formulated with carboxymethyl cellulose } \\
\text { showed longer drug release over } 6 \mathrm{~h}\end{array}$ & [41] \\
\hline $\begin{array}{l}\text { Gelatin/BC hydrogel containing } \\
\text { magnetic nanoparticles }\end{array}$ & Methylene blue & $\begin{array}{l}\text { Triple responsive material: drug release with temperature, low } \mathrm{pH} \text { and } \\
\text { magnetic field. }\end{array}$ & [47] \\
\hline $\begin{array}{l}\text { BC-PEDOT core-shell hybrid } \\
\text { fibers (BC dip-coated with } \\
\text { PEDOT) }\end{array}$ & Diclofenac sodium & Electroresponsive release of the drug & [48] \\
\hline $\begin{array}{l}\text { Poly(N-methacryloyl glycine) } \\
\text { polymerized within BC }\end{array}$ & Diclofenac & $\mathrm{pH}-$ Sensitive (drug retention at $\mathrm{pH} 2.1$ and release at 7.4) & {$[46]$} \\
\hline $\begin{array}{l}\text { Graphene oxide uniformly } \\
\text { embedded into BC }\end{array}$ & Ibuprofen & Controlled release and $\mathrm{pH}$ sensitive release of the drug & [138] \\
\hline
\end{tabular}




\begin{tabular}{|l|l|l|l|}
\hline $\begin{array}{l}\mathrm{pH}-\text { Responsive BC microparticles } \\
\text { for insulin oral administration }\end{array}$ & Insulin & BC protected insulin from enzymes and adhered to intestine \\
\hline $\begin{array}{l}\text { BC nanowhiskers modified to } \\
\text { become anionic, to be DNA } \\
\text { vectors }\end{array}$ & Plasmid DNA & In vitro studies showed DNA transfection \\
\hline $\begin{array}{l}\text { Curcumin-soaked BC. Dried post- } \\
\text { soaking }\end{array}$ & Curcumin & Antibacterial, antifungal and anticancer activity \\
\hline $\begin{array}{l}\text { BC produced with media } \\
\text { containing alginate, forming a } \\
\text { composite }\end{array}$ & Doxorubicin & Increased toxicity of doxorubicin over cancer cells \\
\hline
\end{tabular}

BC: bacterial cellulose; PEDOT: poly(3,4-ethylenedioxythiophene). 
Table 2. Summary of the various in vivo studies with BC or BC-based dressings for wound healing purposes.

\begin{tabular}{|c|c|c|c|}
\hline Formulation & Wound type & Outcome & References \\
\hline $\mathrm{BC}$ containing vaccarin. & $\begin{array}{l}\text { Full thickness } \\
\text { wound }\end{array}$ & BC-vaccarin membranes exhibited faster and better wound healing properties & [55] \\
\hline BC-dextran hydrogel composite & $\begin{array}{l}\text { Full thickness } \\
\text { wound }\end{array}$ & $\begin{array}{l}\text { Dextran promoted fibroblast cell growth in the proliferation stage and helps skin } \\
\text { maturation in the remodeling stage, accelerating of the wound healing process }\end{array}$ & [59] \\
\hline BC-collagen blended hydrogel. & $\begin{array}{l}\text { Full thickness } \\
\text { wound }\end{array}$ & BC-collagen hydrogel promoted a faster and better healing & {$[60]$} \\
\hline $\begin{array}{l}\text { BC-acrylic acid hydrogel composite containing } \\
\text { cells }\end{array}$ & $\begin{array}{l}\text { Full thickness } \\
\text { wound }\end{array}$ & $\begin{array}{l}\text { Both standalone hydrogel and hydrogel containing cells sped-up the healing process. } \\
\text { The fastest one was the hydrogel containing cells }\end{array}$ & {$[61]$} \\
\hline $\mathrm{BC}$ containing Zingiber officinale root extract & $\begin{array}{l}\text { Full thickness } \\
\text { wound }\end{array}$ & $\begin{array}{l}\text { BC containing Zingiber officinale root aqueous extract was slower at healing the } \\
\text { wounds than the components alone, although showed better healing }\end{array}$ & [141] \\
\hline $\begin{array}{l}\text { Standalone Nanoskin }{ }^{\circledR}(\mathrm{BC}-\text { based nanocomposite }) \\
\text { or gelatin-covered Nanoskin }{ }^{\circledR}\end{array}$ & $\begin{array}{l}\text { Full thickness } \\
\text { wound }\end{array}$ & Both BC-based grafts had better healing performance over the autologous skin graft & [142] \\
\hline BC scaffold with porogens of gelatin & $\begin{array}{l}\text { Full thickness } \\
\text { wound }\end{array}$ & $\begin{array}{l}\text { After } 2 \text { weeks, the wounds treated with porogel BC were healed, comparing to the } \\
60 \% \text { wound closure of the ones treated with BC only }\end{array}$ & [143] \\
\hline Hollow BC microspheres & $\begin{array}{l}\text { Full thickness } \\
\text { wound }\end{array}$ & BC hollow spheres showed a faster healing than both $\mathrm{BC}$ microspheres and bulk $\mathrm{BC}$ & {$[17]$} \\
\hline $\mathrm{BC}$ with a pattern of $10 \mu \mathrm{m}$ stripes & Deep-skin injury & $\begin{array}{l}\text { Patterned BC inhibited the inflammatory response and reduced the accumulation of } \\
\text { fibroblasts, significantly decreasing the scar size, comparing to nonpatterned BC }\end{array}$ & [64] \\
\hline $\begin{array}{l}\mathrm{BC} \text { membranes with different } \mathrm{pH} \text { (acidic, neutral } \\
\text { and alkaline) }\end{array}$ & $\begin{array}{l}\text { Full thickness } \\
\text { wound }\end{array}$ & $\begin{array}{l}\text { pH affected the healing efficiency of natural BC, being the acidic one with the best } \\
\text { healing efficiency }\end{array}$ & {$[66]$} \\
\hline $\begin{array}{l}\text { BC containing silk sericin and polyhexamethylene } \\
\text { biguanide }\end{array}$ & $\begin{array}{l}\text { Dermatome- } \\
\text { inflicted wound }\end{array}$ & $\begin{array}{l}\text { No difference in wound healing capacity or speed, however the BC-based dressings } \\
\text { made the wounds much less painful for the patients }\end{array}$ & {$[65]$} \\
\hline $\mathrm{BC}$ containing lidocaine & $\begin{array}{l}\text { Third-degree } \\
\text { burns }\end{array}$ & Loading BC with lidocaine does not interfere with $\mathrm{BC}$ natural wound healing ability & [144] \\
\hline BC-acrylamide hydrogel microparticles & $\begin{array}{l}\text { Partial-thickness } \\
\text { burns }\end{array}$ & $\begin{array}{l}\text { The hydrogel accelerated the healing process by promoting re-epithelialization and } \\
\text { proliferation of fibroblasts }\end{array}$ & [145] \\
\hline $\begin{array}{l}\text { BC dressing containing polyhexamethylene } \\
\text { biguanide and silk sericin }\end{array}$ & $\begin{array}{l}\text { Full thickness } \\
\text { wound }\end{array}$ & Composite showed antimicrobial activity, and showed faster healing than Bactigras ${ }^{\circledR}$ & [56] \\
\hline BC containing Amoxicillin & $\begin{array}{l}\text { Full thickness } \\
\text { wound }\end{array}$ & BC containing antibiotic showed faster healing & [53] \\
\hline $\mathrm{BC}$ containing $\mathrm{TiO}_{2}$ nanoparticles & $\begin{array}{l}\text { Third-degree } \\
\text { burns }\end{array}$ & $\begin{array}{l}\text { The dressing showed antimicrobial activity and enhanced wound healing effect, with } \\
\text { re-epithelization and angiogenesis }\end{array}$ & [57] \\
\hline $\mathrm{BC}$ containing $\mathrm{ZnO}$ nanoparticles & $\begin{array}{l}\text { Third-degree } \\
\text { burns }\end{array}$ & The dressing showed antimicrobial activity and enhanced wound healing effect & [58] \\
\hline
\end{tabular}




\begin{tabular}{|l|l|l|} 
BC containing thymol & $\begin{array}{l}\text { Third-degree } \\
\text { burns }\end{array}$ & The dressing showed antimicrobial activity and enhanced wound healing effect \\
\hline $\begin{array}{l}\text { BC containing different kinds of MMTs: MMT, } \\
\text { Cu-MMT, Na-MMT or Ca-MMT }\end{array}$ & $\begin{array}{l}\text { Partial-thickness } \\
\text { burns }\end{array}$ & The dressings showed antimicrobial activity and enhanced wound healing effect \\
\hline $\begin{array}{l}\text { BC-chitosan biocomposites covered with silk } \\
\text { fibroin or silk fibroin/phosphatidylcholine, loaded } \\
\text { with vitamin K, protamine sulfate or kaolin }\end{array}$ & $\begin{array}{l}\text { Femoral artery } \\
\text { injury }\end{array}$ & $\begin{array}{l}\text { Except for the hemostatic dressings loaded with kaolin, these composites are superior } \\
\text { at controlling hemorrhage compared to the standard gauze on both healthy and } \\
\text { diabetic rat models }\end{array}$ \\
\hline
\end{tabular}

BC: bacterial cellulose; MMT: montmorillonite. 
Table 3. BC-HA composites for bone regeneration.

\begin{tabular}{|c|c|c|c|}
\hline Co-former & Method & Outcome & References \\
\hline $\begin{array}{l}\text { HA and } \\
\text { cellulosic } \\
\text { enzymes }\end{array}$ & $\begin{array}{l}\text { Composites were prepared by immersion of the } \mathrm{BC} \text { membrane } \\
\text { in a HA solution in saturated SBF and subsequent immersion in } \\
\text { the enzyme solution. }\end{array}$ & $\begin{array}{l}\text { Composite preparation strategy improves the calcium phosphates molecules } \\
\text { formed in the composite; almost complete in vitro degradation and good } \\
\text { biocompatibility with MC } 3 \text { T3-E1 cells. }\end{array}$ & [126] \\
\hline $\begin{array}{l}\text { Gelatin, } \\
\text { procyanidins, } \\
\text { with gelatin }\end{array}$ & $\begin{array}{l}\mathrm{BC} \text { scaffolds prepared through emulsion freeze-drying were } \\
\text { immersed in a gelatin solution. Subsequently, BC-gelatin was } \\
\text { immersed in procyanidin solution for cross-linking, and then } \\
\text { soaked in a } \mathrm{CaCl}_{2} \text { solution (for HA deposition). }\end{array}$ & $\begin{array}{l}\text { Scaffolds exhibit improved mechanical properties, adhesion, viability, } \\
\text { osteogenic differentiation, and proliferation of human BMSCs. In vivo } \\
\text { studies with nude mice and rabbits show enhanced bone formation when } \\
\text { compared to, pristine BC. }\end{array}$ & [148] \\
\hline $\begin{array}{l}\text { Gelatin and } \\
\text { nano-HA }\end{array}$ & $\begin{array}{l}\text { Construction of a double-network by incorporation of nano-HA } \\
\text { particles in BC nodules and subsequent incorporation of gelatin. }\end{array}$ & $\begin{array}{l}\text { Improved mechanical properties and cell adhesion as well as proliferation } \\
\text { of rat BMSCs. }\end{array}$ & [149] \\
\hline HA & $\begin{array}{l}\text { Microporous BC scaffolds prepared by laser patterning were } \\
\text { oxidized using sodium periodate and then mineralized with } \\
\text { nano-HA by immersion in calcium and phosphate solutions. }\end{array}$ & $\begin{array}{l}\text { Scaffold exhibit in vitro degradation of } 13-25 \% \text {. Furthermore, human } \\
\text { BMSCs show adherence and viability when cultured with the prepared } \\
\text { scaffolds. }\end{array}$ & {$[150]$} \\
\hline $\begin{array}{l}\text { Collagen, Ap } \\
\text { and OGP and } \\
\text { OGP(10-14) }\end{array}$ & $\begin{array}{l}\text { Ap was integrated in BC-collagen composites by in situ } \\
\text { precipitation. OGP and OGP }(10-14) \text { were incorporated by } \\
\text { adsorption. }\end{array}$ & $\begin{array}{l}\text { Composite induces cell growth at early time points relatively to BC-Ap } \\
\text { composite. The presence of OGP peptide lead to the early development of } \\
\text { osteoblastic phenotype. }\end{array}$ & [151] \\
\hline Nano-HA & $\begin{array}{l}\text { Nano-HA was deposited in the BC membrane by a biomimetic } \\
\text { approach. BMSCs were then seeded and allowed to proliferate } \\
\text { and differentiate in the prepared scaffolds. }\end{array}$ & $\begin{array}{l}\text { BC-(nano-HA) scaffolds show good biocompatibility, enhanced } \\
\text { proliferation of BMSCs and induction of osteogenic differentiation through } \\
\text { modulation of p38 signal transduction pathway. The composites seem to } \\
\text { significantly improve the bone formation and osteogenic ability in vivo. }\end{array}$ & [152] \\
\hline $\mathrm{HA}$ and $\mathrm{SF}$ & $\begin{array}{l}\text { Comparison between } \mathrm{BC}-\mathrm{HA} \text { and } \mathrm{BC}-\mathrm{HA}-\mathrm{SF} \text { composites, using } \\
\mathrm{SF} \text { from different sources. HA was initially incorporated in the } \\
\mathrm{BC} \text { trough immersion in a acetic acid solution containing } \\
\mathrm{Ca}\left(\mathrm{NO}_{3}\right)_{2} \cdot 4 \mathrm{H}_{2} \mathrm{O} \text { and }\left(\mathrm{NH}_{4}\right)_{2} \mathrm{HPO}_{4} \text {, and precipitation was induced } \\
\text { by } \mathrm{NH}_{3} \text {-treatment. The } \mathrm{BC}-\mathrm{HA} \text { composites were finally soaked } \\
\text { in the respective SF solutions. }\end{array}$ & $\begin{array}{l}\text { BC-HA-Antheraea yamamai SF exhibited improved mechanical strength, } \\
\text { in vitro cytocompatibility and induced a higher cell proliferation than } \\
\text { BC-HA-Bombyx mori SF. }\end{array}$ & [153] \\
\hline
\end{tabular}


BC-HA-chondroitin sulphate composites showed no cytotoxicity.

\section{chondroitin}

and Addition of chondroitin sulfate to the fermentation medium

sulfate followed by a biomimetic process for the precipitation of heterogeneous calcium phosphate.

$\beta$-Tri-calcium phosphate, HA, PVP, carboxymethylcellulose and/or BC, PEG, agar, glycerin and water were processed by

Calcium

phosphate,

$\mathrm{CaCO}_{3}$ solvent casting method and the hydrogels formed by physical cross-linking. Filling of the $\mathrm{BC}$-based hydrogel with calcium phosphate and $\mathrm{CaCO}_{3}$ was performed trough the in vitro mineralization process.

SA, chitosan, SA, BC nanocrystals, and HA were initially treated in solution gelatin, HA-D-

glucono- $\delta$ and D-glucono- $\delta$-lactone was added as cross-linker. The prepared hydrogel was soaked alternately in a chitosan solution and in a gelatin solution.

lactone

$\mathrm{BC}$ membrane was mixed with agarose and gelatin. This mixture

\section{Gelatin,}

agarose,

procyanidin,

and HA

was processed by emulsion freeze-drying technique to form

porous scaffold. The resulting material was immersed in a gelatin solution and subsequently in a procyanidin solution for cross-linking gelatin. The porous scaffolds were soaked in a $\mathrm{CaCl}_{2}$ solution and subsequently immersed in an SBF solution.
The hydrogel scaffolds exhibit a compressive strength value (0.24-0.60 MPa) like the trabecular bones and anti-bacterial activity against S. aureus. When incubated with the prepared materials, the Lep-3 cells show significant cell viability.

3D scaffolds exhibit enhanced compressive strength and regulate bioabsorption. In vitro assays with osteoblastic MC3T3-E1 cells indicate that the arginine-glycine-aspartic repetitive motifs of gelatin enhance the attachment, proliferation and differentiation of MC3T3 cells.

BC-gelatin-procyanidin-HA show increased mechanical properties over the $\mathrm{BC}, \mathrm{BC}$-gelatin, and $\mathrm{BC}$-gelatin-procyanidin. In vitro assays with human BMSCs indicate that BC-gelatin-procyanidin-HA porous scaffold shows improved viability, adhesion, proliferation and osteogenic differentiation. In vivo tests with mice and rabbits also indicate that this scaffold has the best osteogenesis, relatively to the three other scaffolds.

Ap: apatite; BC: bacterial cellulose; BMSCs: bone marrow-derived mesenchymal stem cells; HA: hydroxyapatite; OGP: osteogenic growth factor; PEG: polyethyleneglycol;

PVP: Polyvinylpyrrolidone; SA: sodium alginate; SBF: synthetic body fluid; SF: silk fibroin. 
Table 4. BC composites, method and in vitro and in vivo studies regarding bone regeneration.

\begin{tabular}{|c|c|c|}
\hline Method & Outcome & References \\
\hline $\begin{array}{l}\text { Cross-linking of a mixture of disintegrated } \mathrm{BC} \\
\text { membrane, MWCNCs-COOH, sodium alginate and } \\
\text { D-mannitol. }\end{array}$ & The prepared scaffolds show an enhanced osteoblast viability, proliferation, and adhesion. & [158] \\
\hline $\begin{array}{l}\text { Preparation of bioabsorbable } \mathrm{BC} \text { membranes by } \\
\text { electron beam irradiation. }\end{array}$ & $\begin{array}{l}\text { Electron beam irradiation increased the bioabsorbability and increased the cell viability of NIH } 3 \text { T3. The } \\
\text { treated BC membranes show an enhancement in the in vivo bone regeneration on calvarial defects in Sprague- } \\
\text { Dawley rats. }\end{array}$ & [159] \\
\hline $\begin{array}{l}\text { In vitro and in vivo comparison between } \\
\text { bioabsorbable } \mathrm{BC} \text { membranes treated by electron } \\
\text { beam irradiation and collagen membranes. }\end{array}$ & $\begin{array}{l}\text { In vitro assays with NIH3 } 3 \text { cells did not show statistically significant differences in terms of cell adhesion } \\
\text { and proliferation. The differences obtained in the in vivo studies with beagle dogs were not statistically } \\
\text { relevant regarding new bone area, bone-to-implant contact and remaining bone substitute volume. }\end{array}$ & [160] \\
\hline $\begin{array}{l}\text { BC nanoribbons and SF aqueous solutions were } \\
\text { poured into molds, in different ratios, and freeze-dried } \\
\text { with temperature gradients. }\end{array}$ & $\begin{array}{l}\text { The composites exhibit radial lamellar patterns and gradient lamellar gap distance, these features allow an } \\
\text { eight-fold increase in compression modulus and six-fold enhancement in compression strength. Furthermore, } \\
\text { the prepared scaffolds exhibit an enhanced in vitro bioactivity, proliferation, and bone-cell adhesion of } \\
\text { MC3T3 cells. }\end{array}$ & [161] \\
\hline $\begin{array}{l}\text { Implantation of BC membranes with different } \\
\text { thicknesses in rat calvarian defect models to study } \\
\text { membranes' suitable thickness for guided bone } \\
\text { regeneration. }\end{array}$ & $\begin{array}{l}\text { BC membrane with } 0.10 \mathrm{~mm} \text { of thickness exhibits the formation of the highest volume of new bone and the } \\
\text { greater percentage of new bone area. }\end{array}$ & [162] \\
\hline $\begin{array}{l}\text { Ex situ modification of } \mathrm{BC} \text { by immersion in fisetin } \\
\text { solutions with different concentrations. }\end{array}$ & $\begin{array}{l}\text { The BMSCs seeded in the BC-fisetin scaffold show an increase in cell viability and differentiation into } \\
\text { osteoblasts. }\end{array}$ & [163] \\
\hline $\begin{array}{l}\text { Evaluation of BMSCs behavior when cultured in a BC } \\
\text { membrane. }\end{array}$ & $\begin{array}{l}\text { The BMSCs were able to adhere, expand, and biointegrate when cultured in a } \mathrm{BC} \text { membrane. The } \mathrm{BC} \\
\text { membrane has low toxicity and cytotoxicity. }\end{array}$ & [164] \\
\hline
\end{tabular}


Coating of Ti6Al7Nb scaffolds with $\mathrm{BC}$ by immersion in Komagataeibacter xylinus bacteria

culture medium, and subsequent soaking in a non-coated implants. Furthermore, the incorporation of gentamycin inhibited the growth of Staphylococcus

BC-coated scaffolds display a significantly lower cytotoxicity for osteoblasts and fibroblasts relatively to the aureus.

BC: bacterial cellulose; BMSCs: bone marrow-derived mesenchymal stem cells; MWCNCs: multi-walled carbon nanotubes; SF: silk fibroin. 

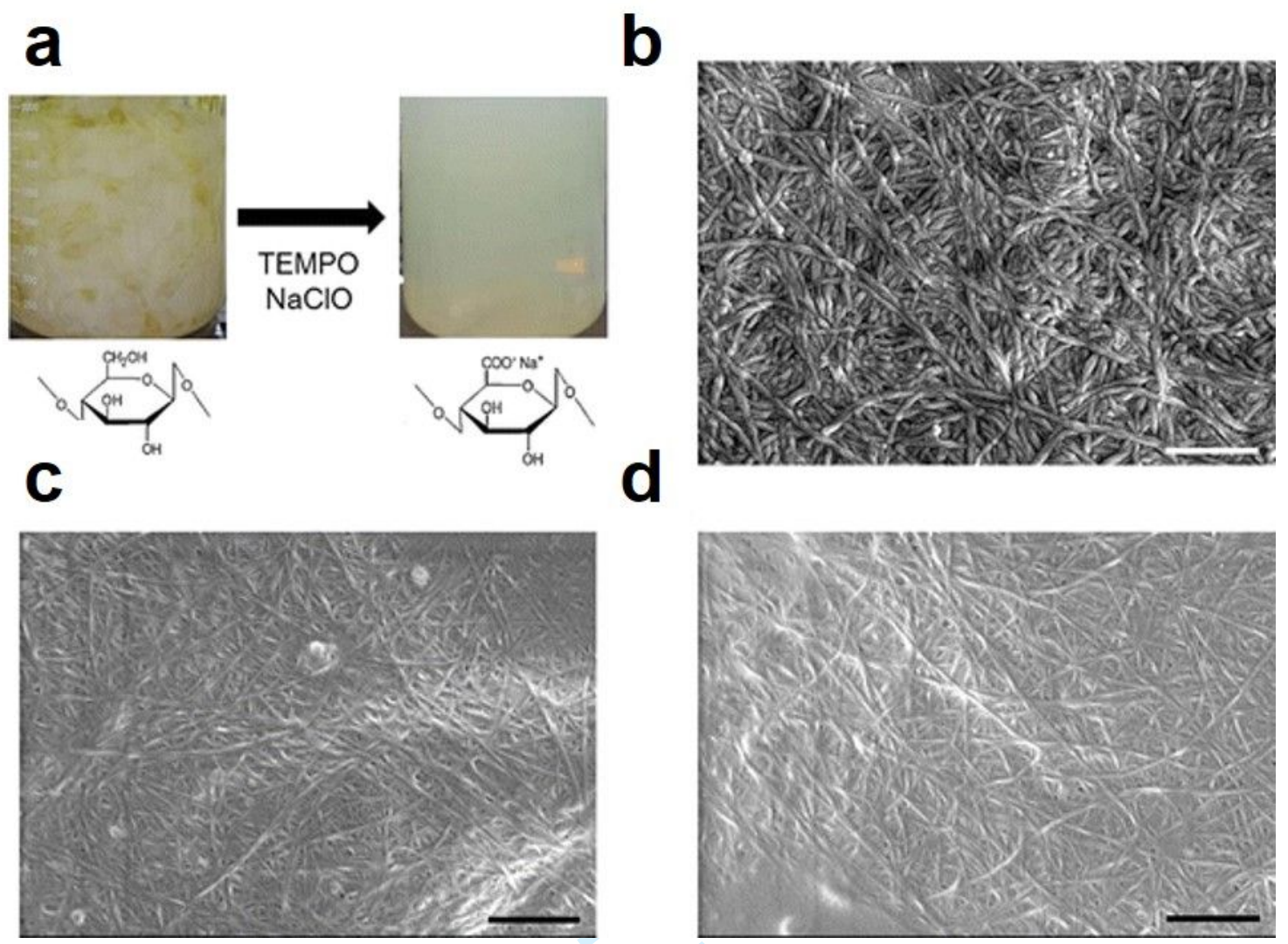

Figure 1. (a) Photographs showing the appearance of the $\mathrm{BC}$ membrane before and after the TEMPO-mediated oxidation, as well as the representation of the chemical alteration in the glucose units in cellulose. Scanning electron microscopy images of (b) BC membrane, (c) TEMPOmediated BC nanofibers, and (d) water in oil emulsion of TEMPO-mediated BC nanofibers deposited on porcine skin. Scale bar equals to $1 \mu \mathrm{m}$. Reprinted with permission from ref. ${ }^{[69]}$. 
a
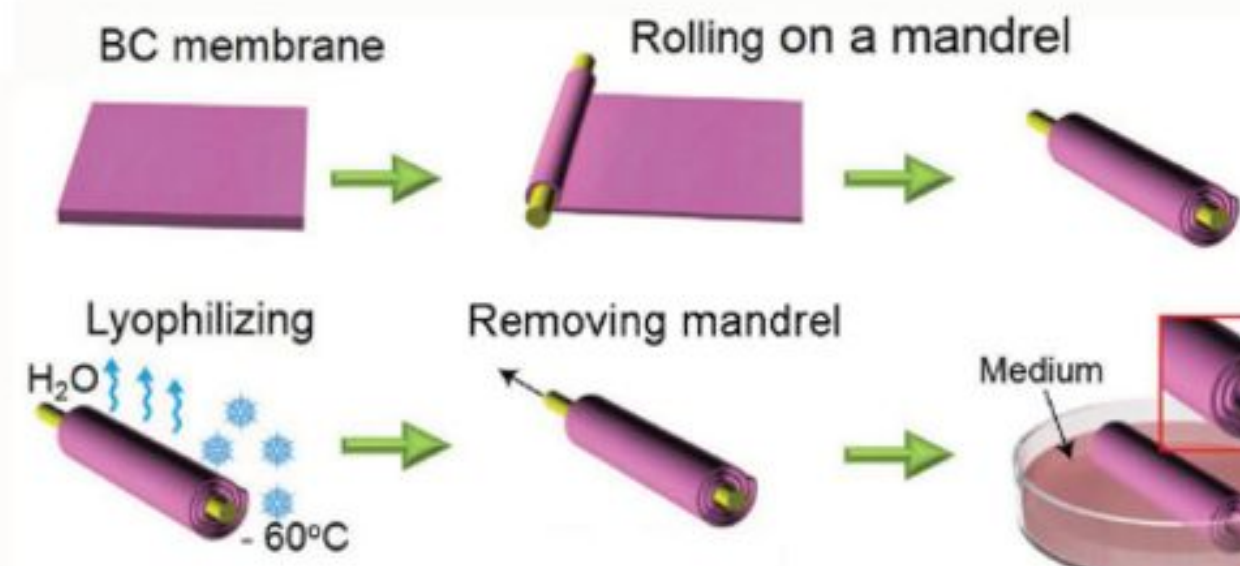

b

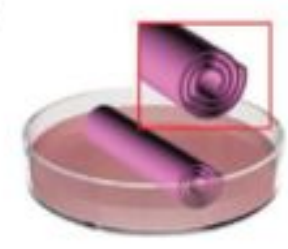

Re-spreading

Injecting cells Cell patterns Peeling off
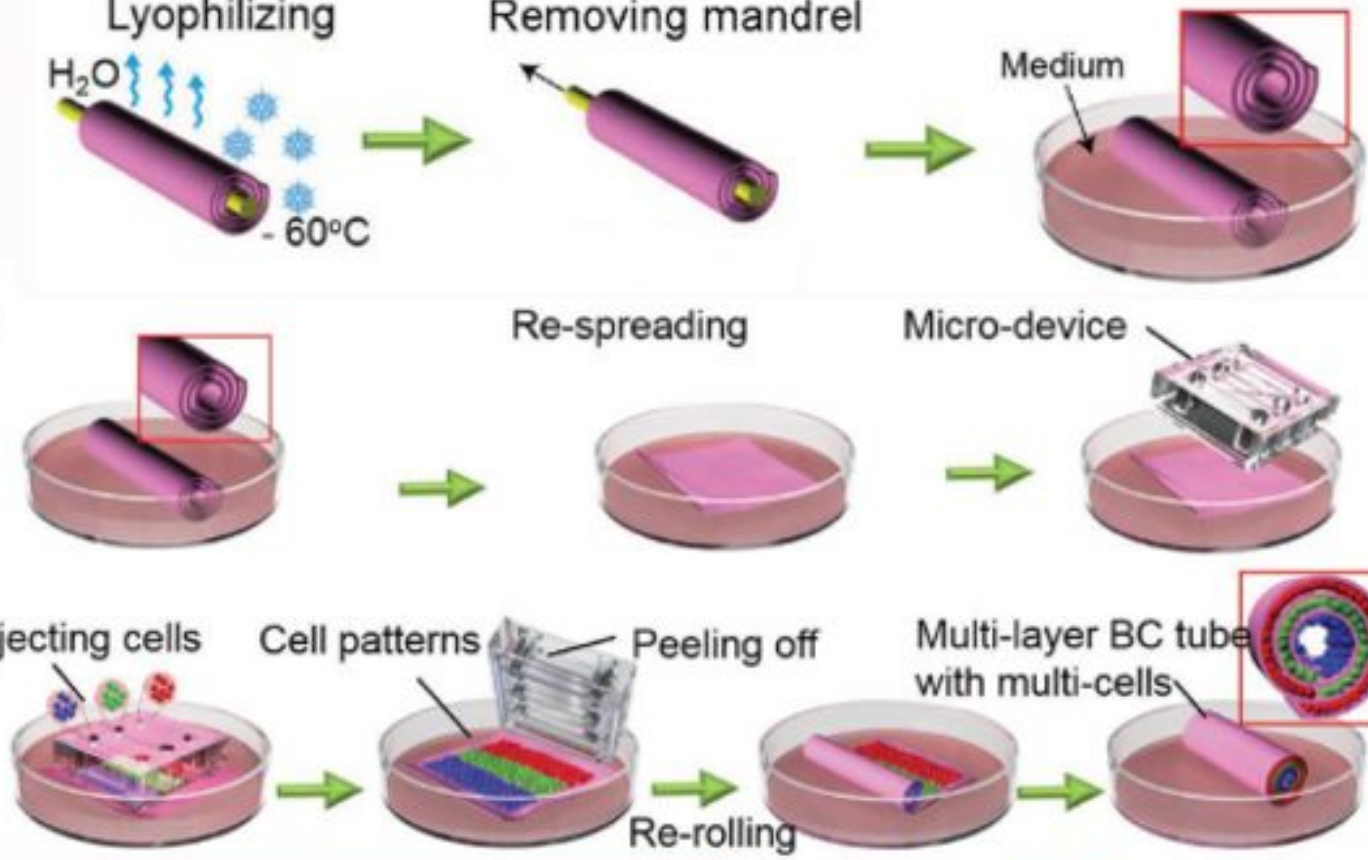

Micro-device
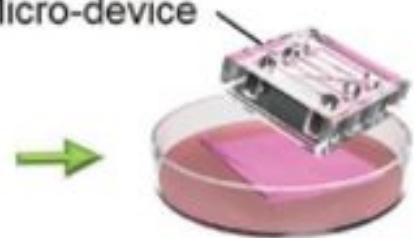

c

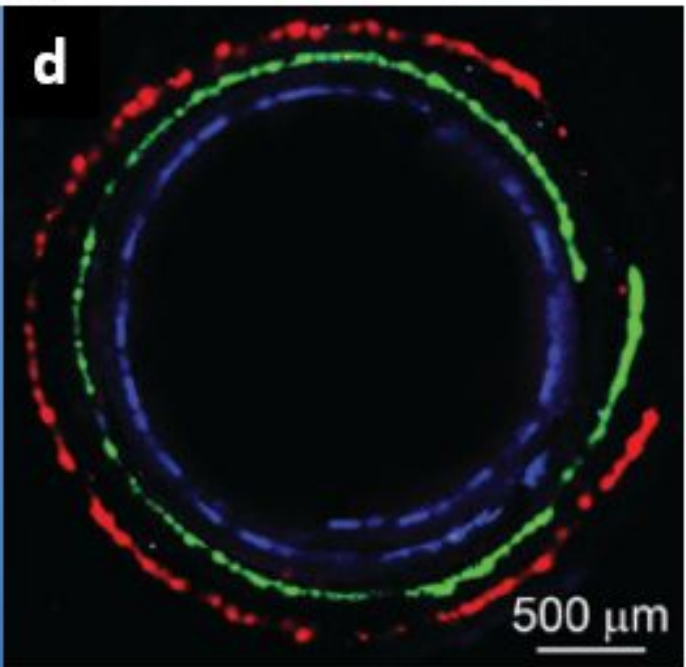

Figure 2. Preparation and cell loading of the three-layered BC tube. (a) Scheme of the preparation process of the BC tube. (b) Scheme of the loading of three cell types on the BC membrane and its rolling into a three-layered cell-laden tube. (c) Photograph of a lyophilized BC tube. (d) Micrograph of the fluorescent staining of the different loaded cells. Reprinted with permission from ref. ${ }^{[73]}$. 

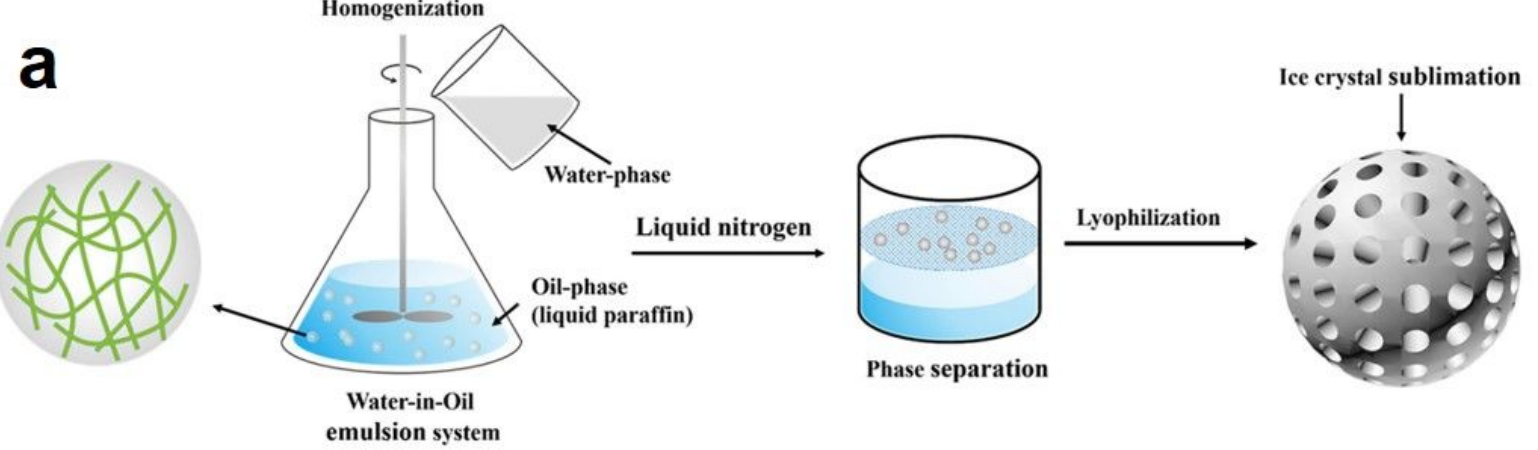

b

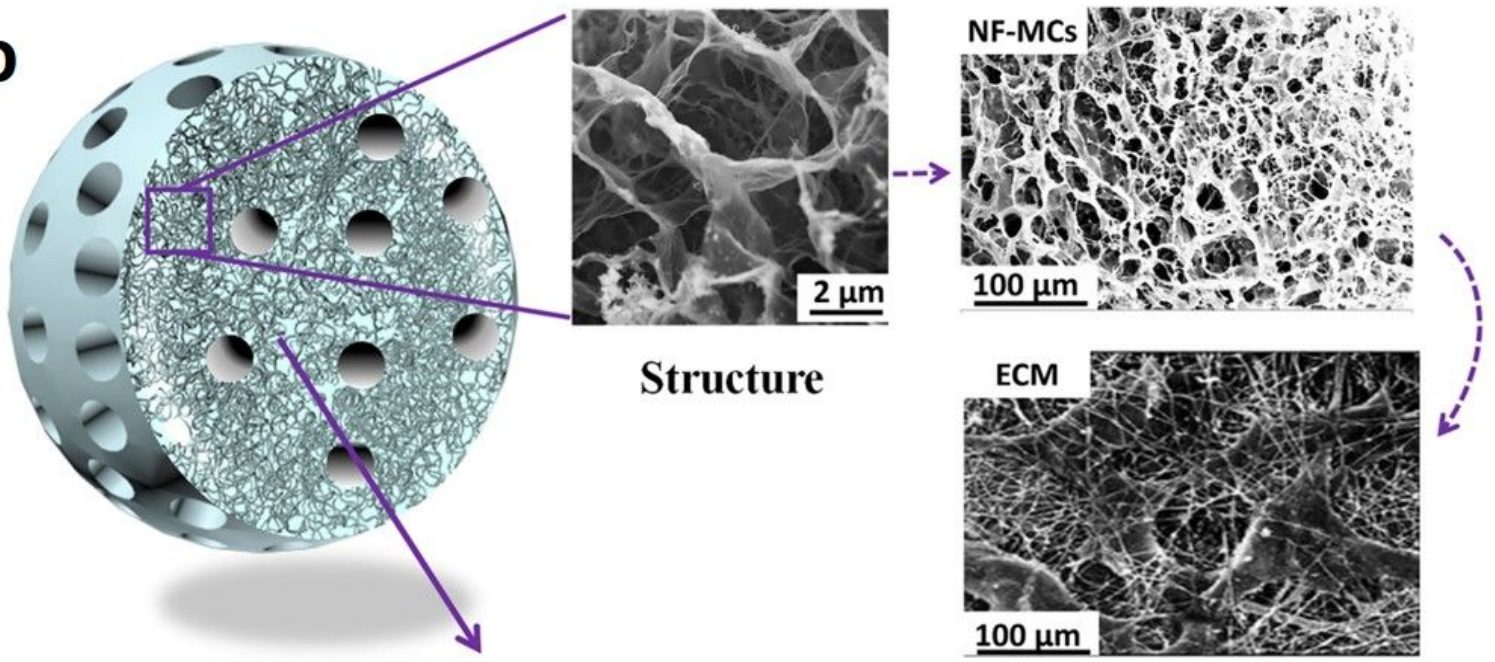

Composition

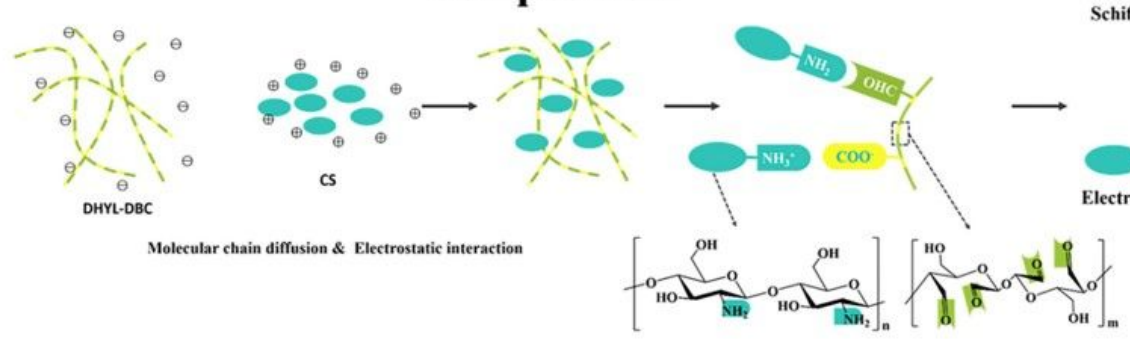

Schiff base reaction

Figure 3. Illustration of the nanofibrous microcarriers mimicking the ECM. (a) Schematic representation of the steps involved in the preparation of the nanofibrous microcarriers. (b) Scheme illustrating the nanofibrous microcarriers and its composition, as well as scanning electron microscopy images. Reprinted with permission from ref. ${ }^{[120]}$. 
a

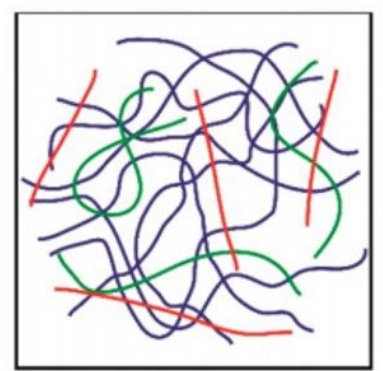

Polymer solution
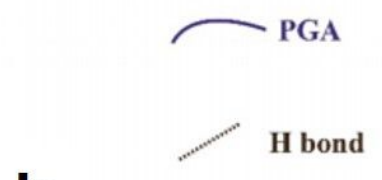

b

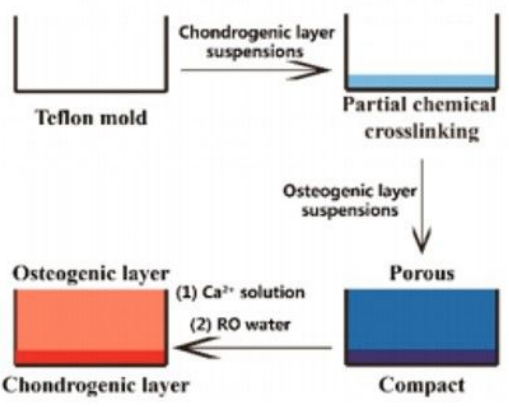

\section{EDC/NHS}
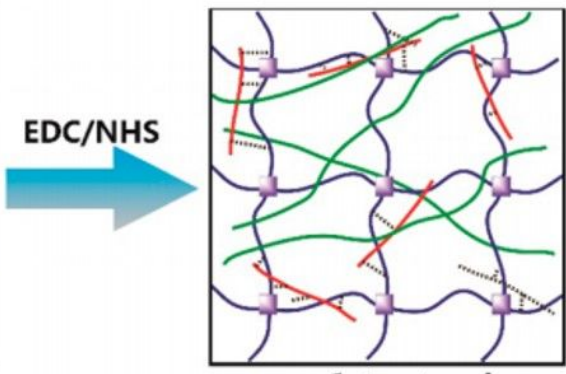

1st network
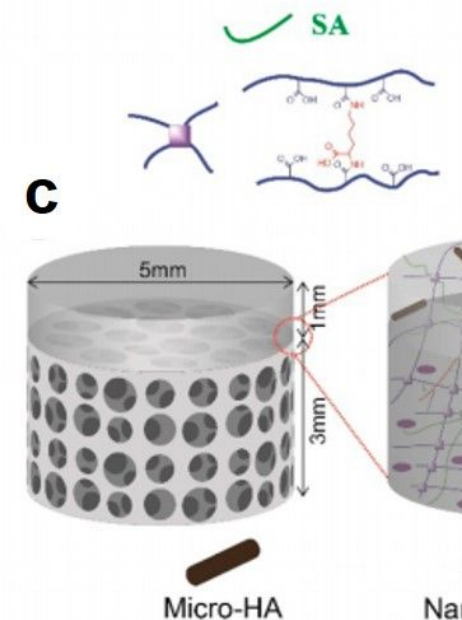

(1) $1 \mathrm{M} \mathrm{Ca}^{2+}$

(2) $48 \mathrm{~h}$

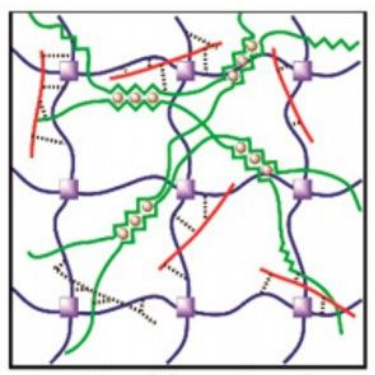

Double network

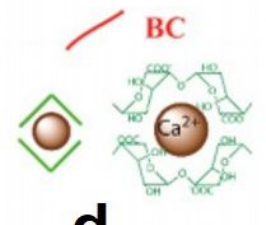

d

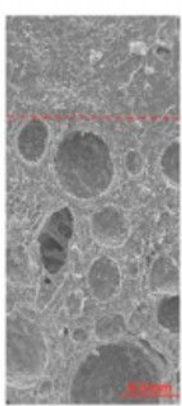

Figure 4. Schematic representation of the steps involved in the hydrogels formation and structures prepared. (a) Graphical representation of the formation of the hydrogels. (b) Stages of the formation of bilayer hydrogel scaffolds. (c) Graphic representation of the structure of the bilayer hydrogel. (d) Scanning electron microscopy images of the obtained scaffolds. Reprinted with permission from ref. ${ }^{[122]}$. 

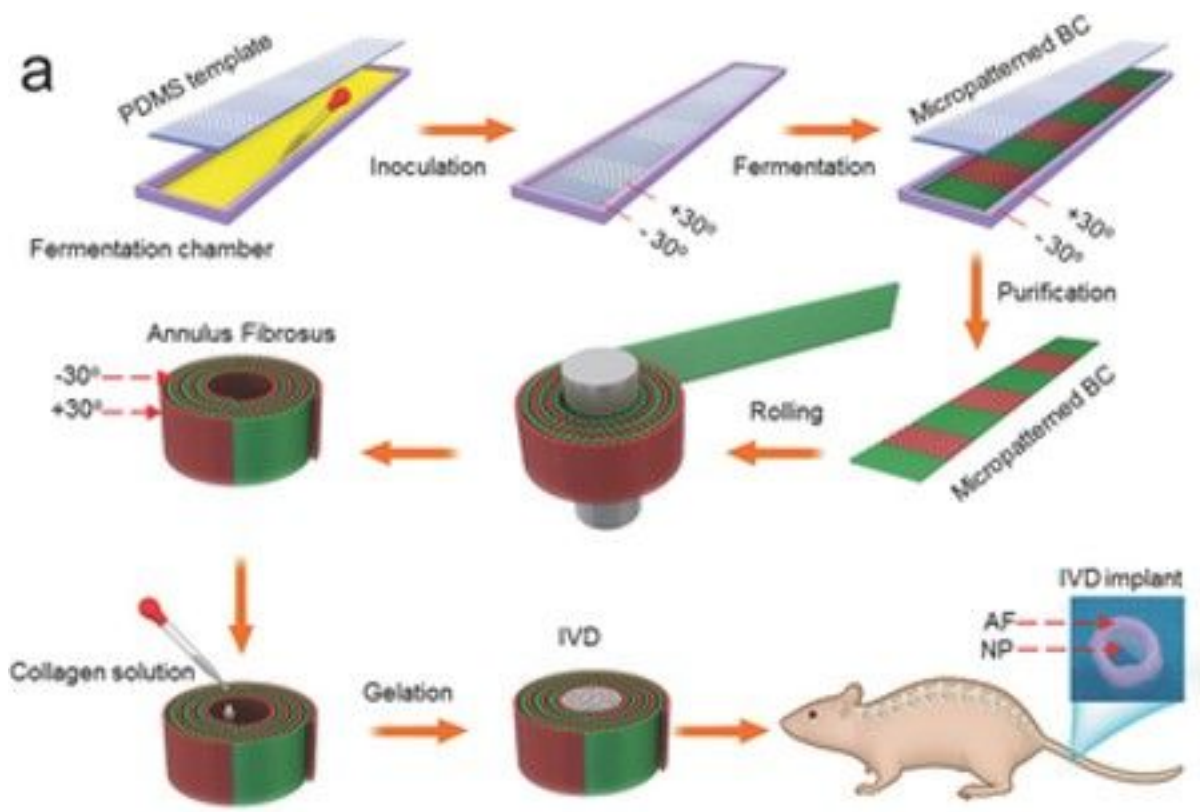

b

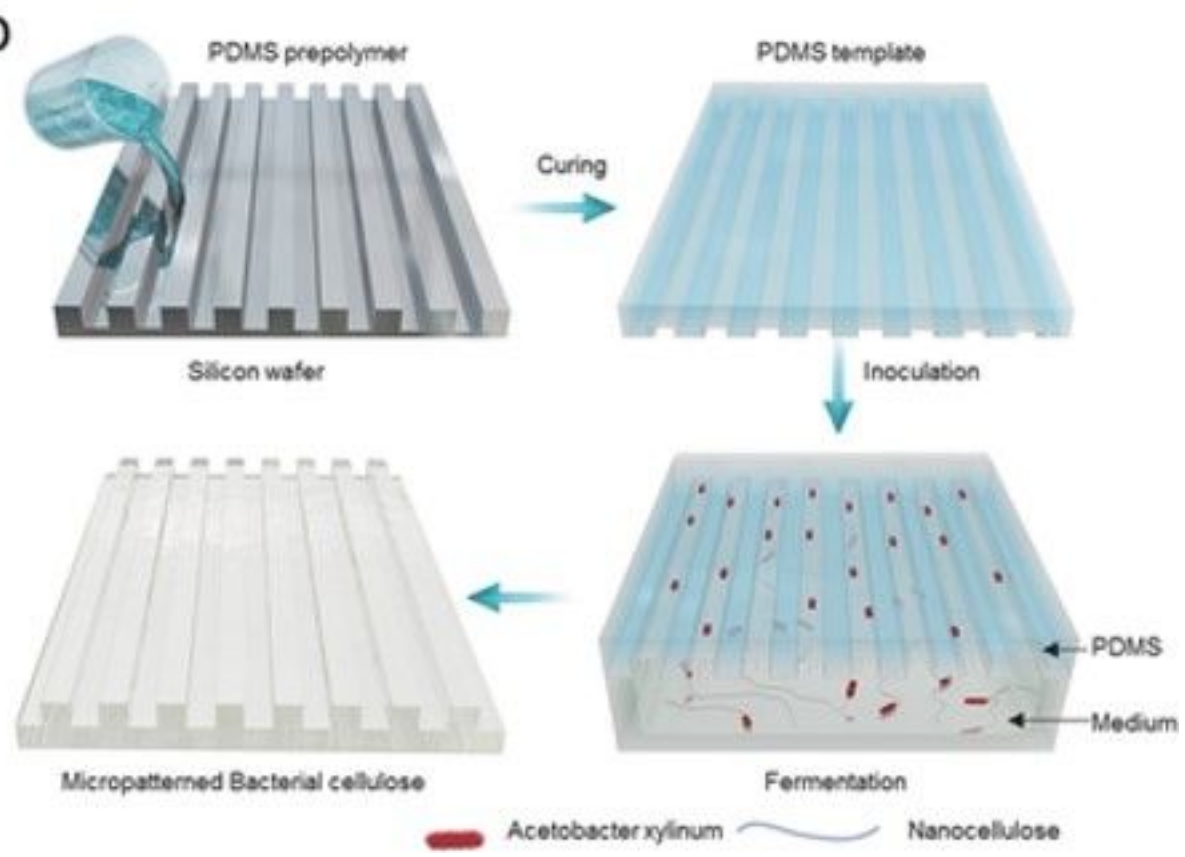

Figure 5. (a) Schematic representation of the steps for production of the total intervertebral discs. Micropatterned BC was manufactured by fermentation of Acetobacter xylinum in a PDMS template with a micropattern of $10 \mu \mathrm{m}$ microgrooves aligned in $\pm 30^{\circ}$ direction in alternating neighboring regions. The micropatterned $\mathrm{BC}$ was rolled to form a multilamellar structured annulus fibrosus. Then, a type II collagen solution was injected in the hole of the annulus fibrosus prepared to form the nucleus pulposus. The prepared intervertebral disc was implanted in a rat model. (b) Schematic illustration of the fabrication of the micropatterned BC. Firstly, a PDMS template with a micropattern was produced based on a $\mathrm{Si}$ wafer through the replica molding method. Subsequently the bacteria were cultured in the PDMS template and the micropatterned BC membrane was created at the liquid-PDMS template interface. Reprinted with permission from ref. ${ }^{[124]}$. 


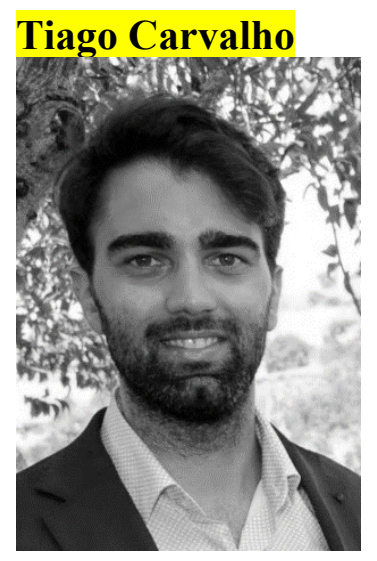

Tiago Carvalho is currently a $\mathrm{PhD}$ student enrolled in the doctoral program of Nanosciences and Nanotechnology, at the University of Aveiro, in partnership with the University of Helsinki. Since 2014, his research focus has been on the development of biomaterials, mostly based on bacterial cellulose, protein nanofibers, gelatin and chitosan. Previously, he participated in the Lifelong Learning Programme Leonardo da Vinci, at the Institut des sciences moléculaires de Marseille. His previous degrees were obtained at the University of Aveiro. During his master studies, he was an exchange student at the University of Novi Sad, under the Campus Europae Programme.

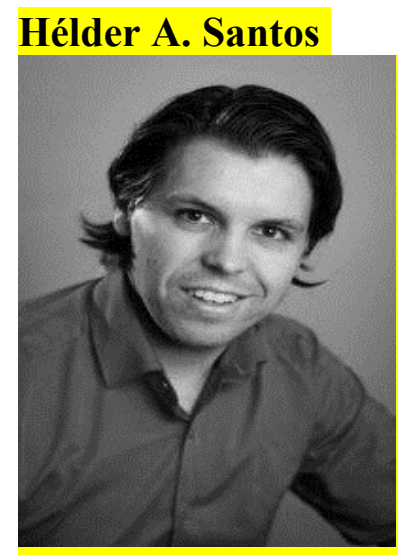

Hélder A. Santos is currently working as an Associate Professor (tenure-track) at the Faculty of Pharmacy, University of Helsinki. He is the Head of Nanomedicines and Biomedical Engineering Group, Head of Preclinical Drug Formulation and Analysis Group, Head of Division of Pharmaceutical Chemistry and Technology, and Director of Doctoral Programme in Drug Research. His main research focus is in the use of biodegradable and biocompatible nanoporous silicon nanomaterials, polymers, the application of microfluidics technology for nanoparticle production for simultaneous controlled drug delivery, diagnostic and treatment of cancer, diabetes, and cardiovascular diseases, and further translation of these nanotechnologies into the clinic. 
In this review it is overviewed the latest state-of-the-art usage of bacterial cellulose (BC) on three important areas of the biomedical fields: delivery systems, wound dressing and healing materials, and tissue engineering for regenerative medicine. $\mathrm{BC}$ is a promising biopolymer that is shown to be an effective and versatile carrier for delivery systems, a safe and multi-customizable patch or graft for wound dressing and healing applications, and a material that can be further tuned to better adjust for each tissue engineering application.

Keywords: Bacterial cellulose; Biomedical applications; Drug delivery; Regenerative medicine; Wound healing

T. Carvalho, G. Guedes, F. L. Sousa, C. S. R. Freire, H. A. Santos

Latest advances on bacterial cellulose-based materials for wound healing, delivery systems and tissue engineering

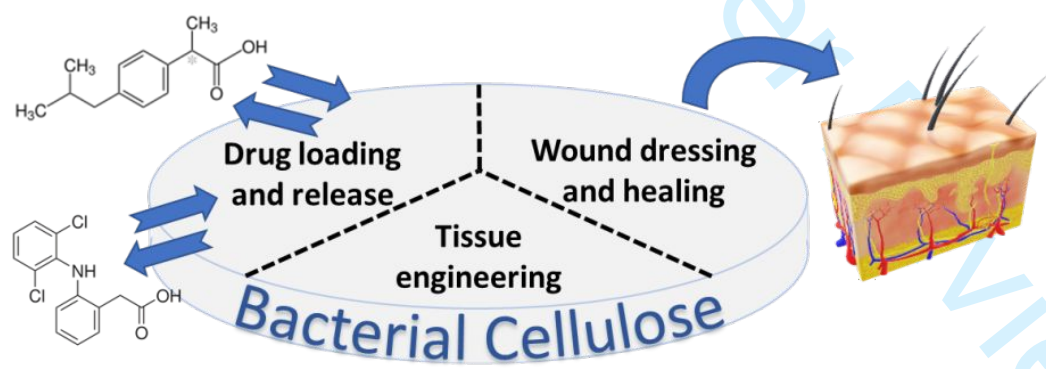



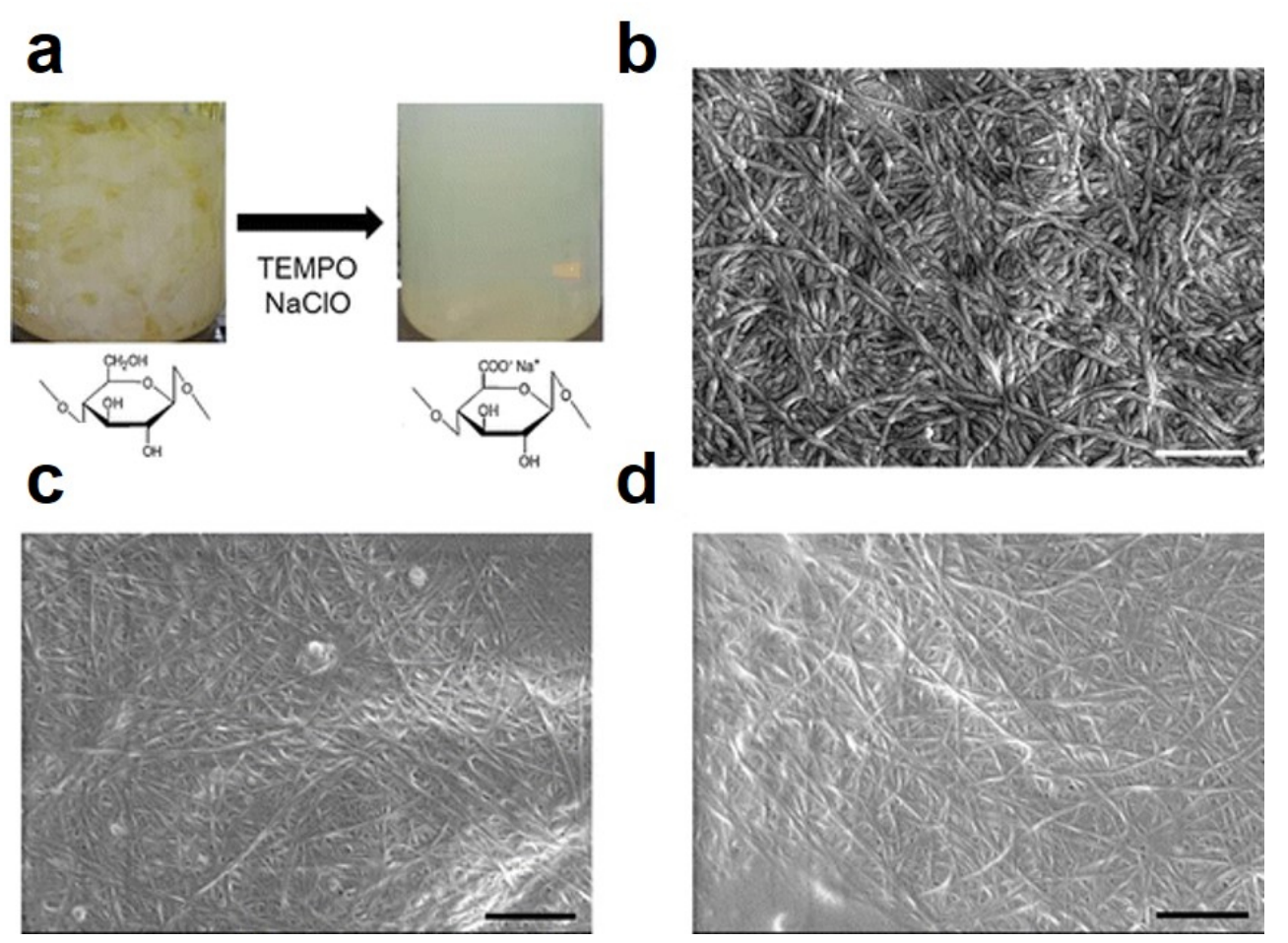

Figure 1 
a
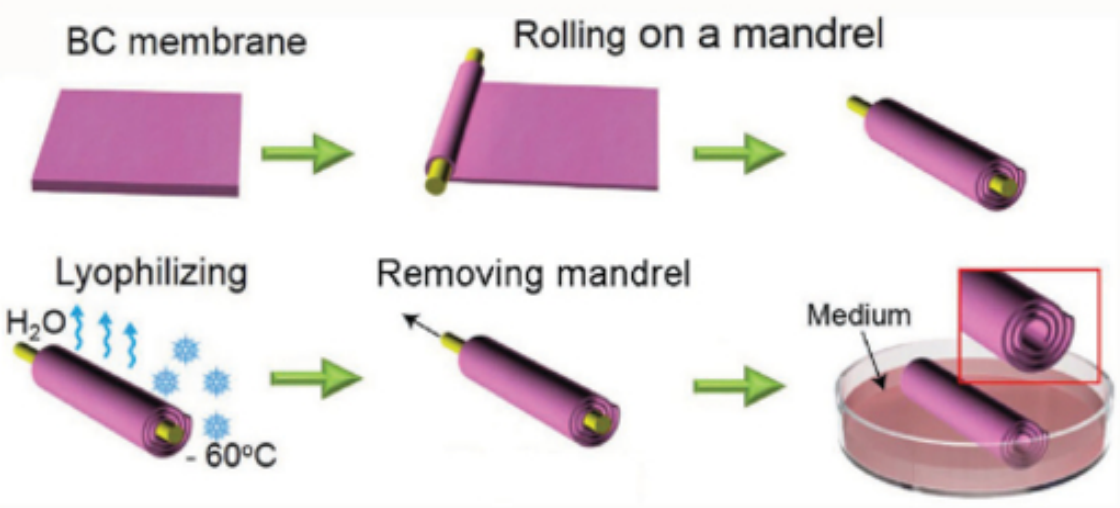

b
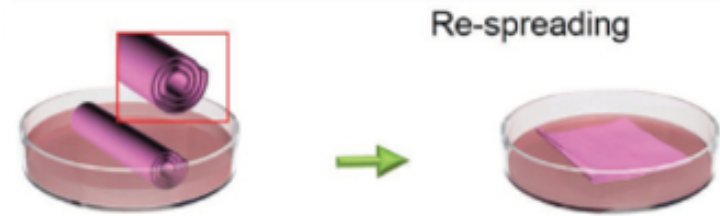

Injecting cells

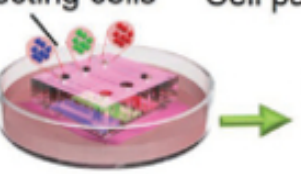

c

\section{$2 \mathrm{~mm}$}

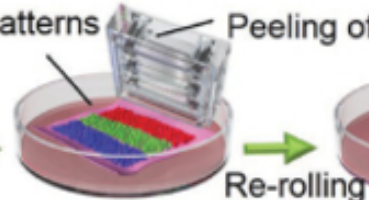

Multi-layer BC tube 6 with multi-cells

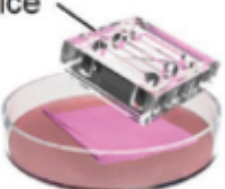

Micro-device
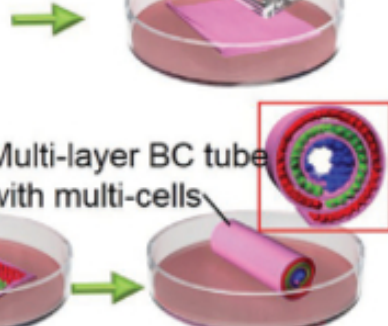

\section{d}

Figure 2 

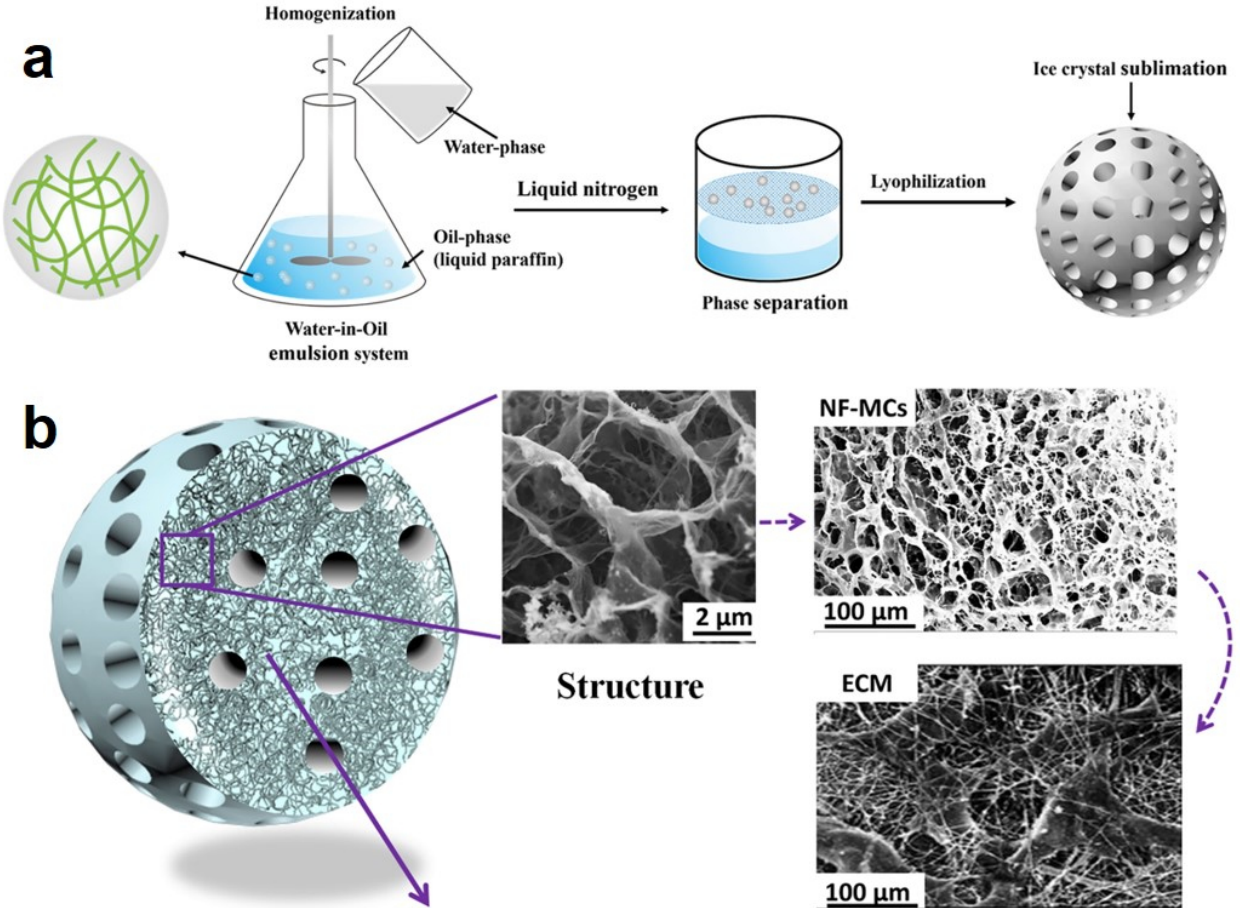

Composition

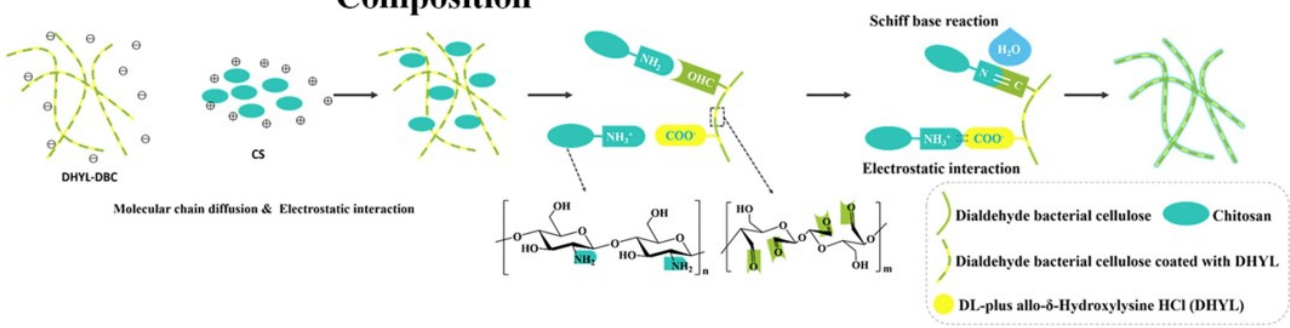

Figure 3 

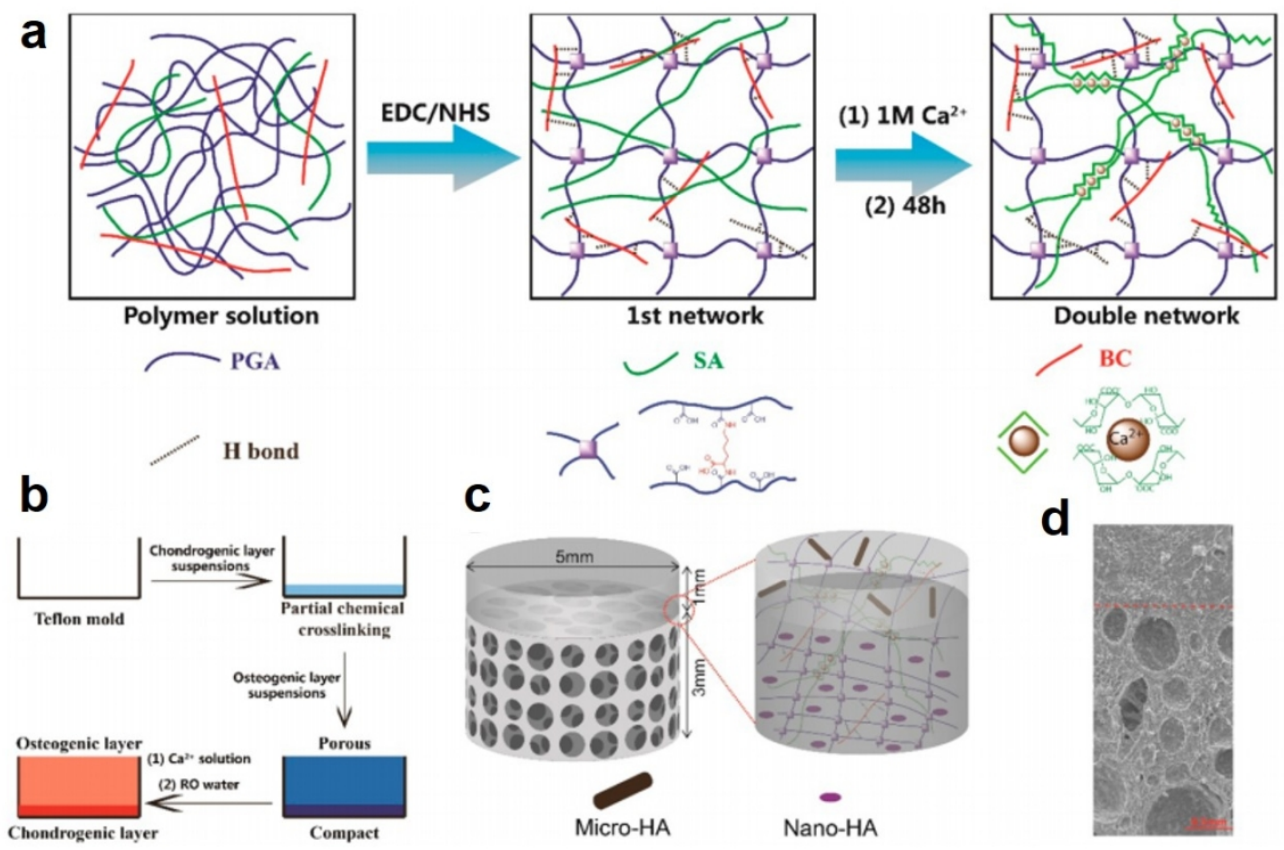

C

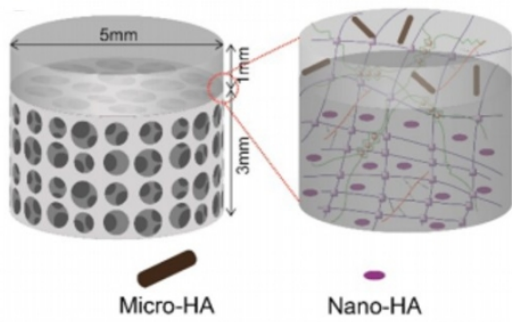

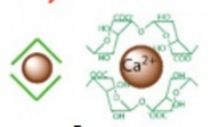

d

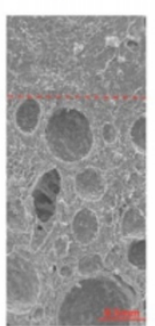

Figure 4

Wiley-VCH 

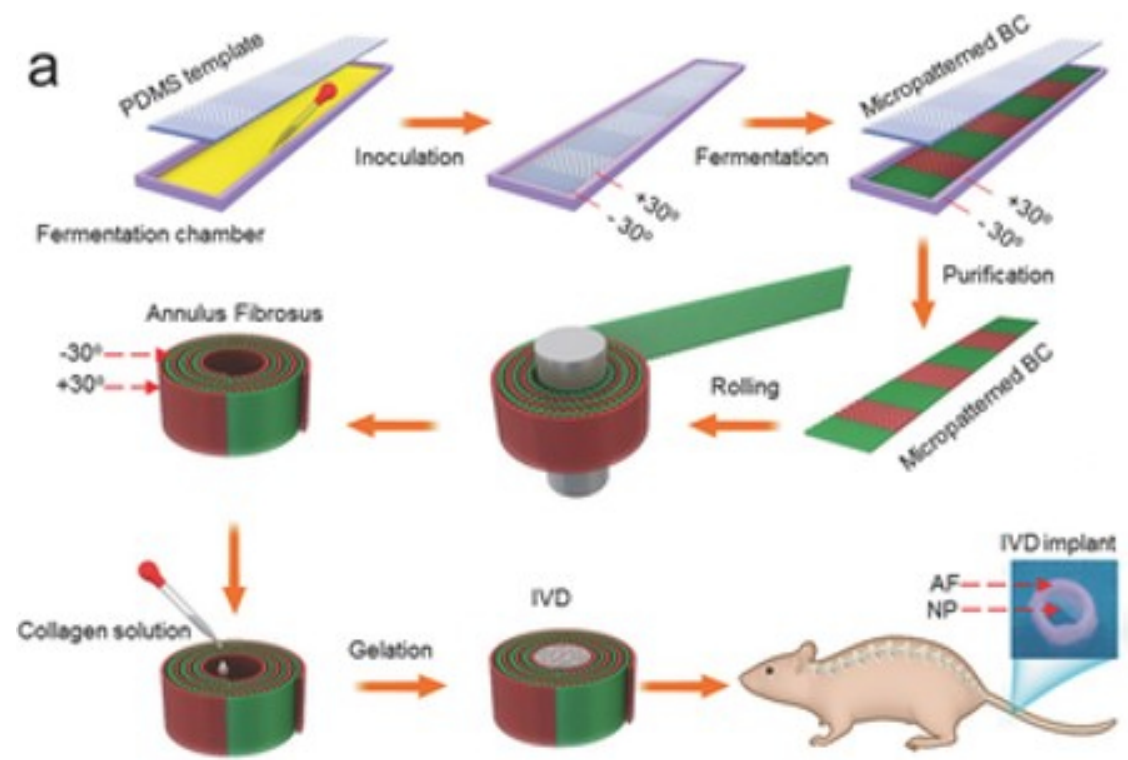

b
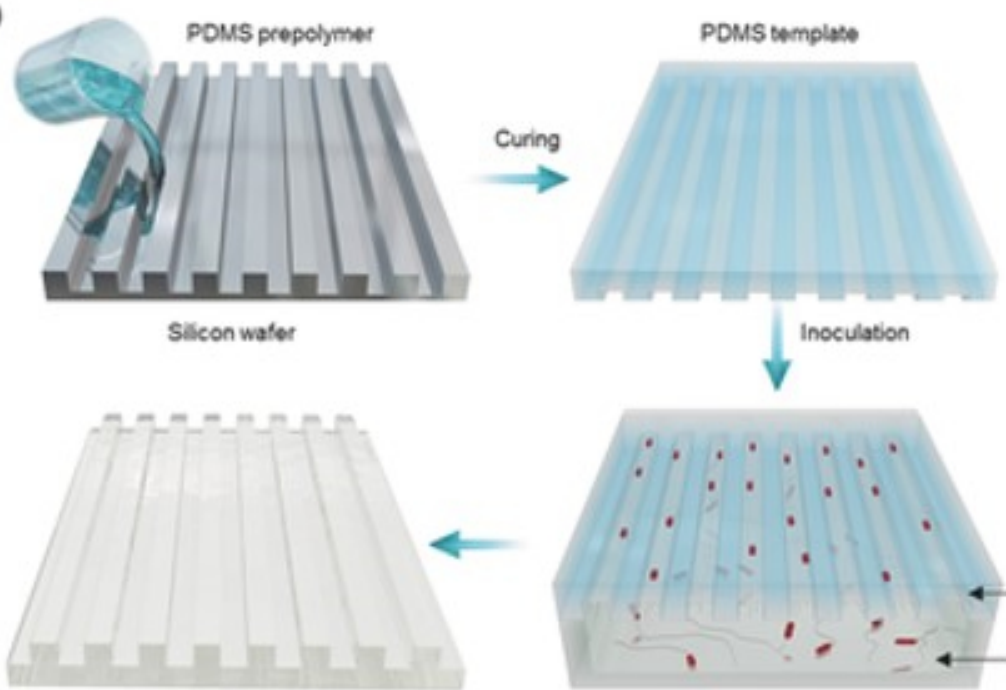

Micropatterned Becterial cellulose

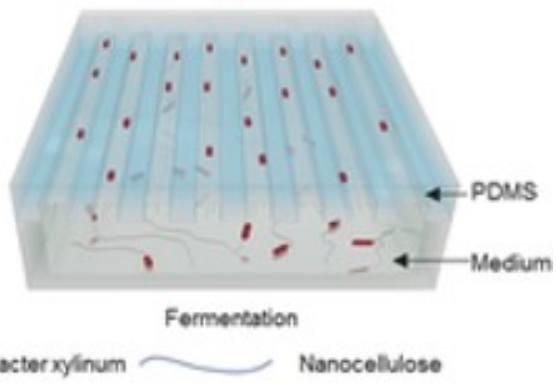

Figure 5

Wiley-VCH 


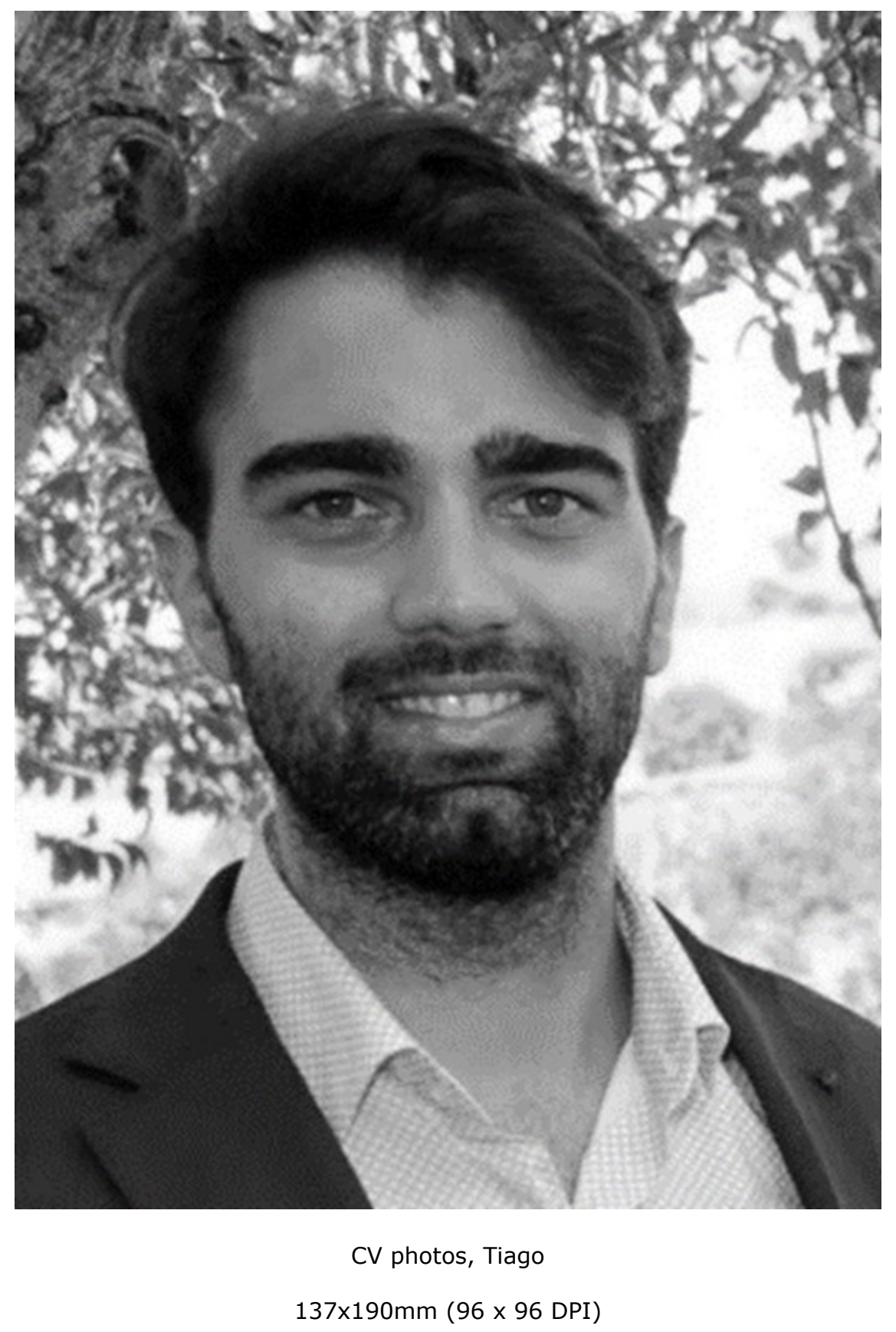

Wiley-VCH 


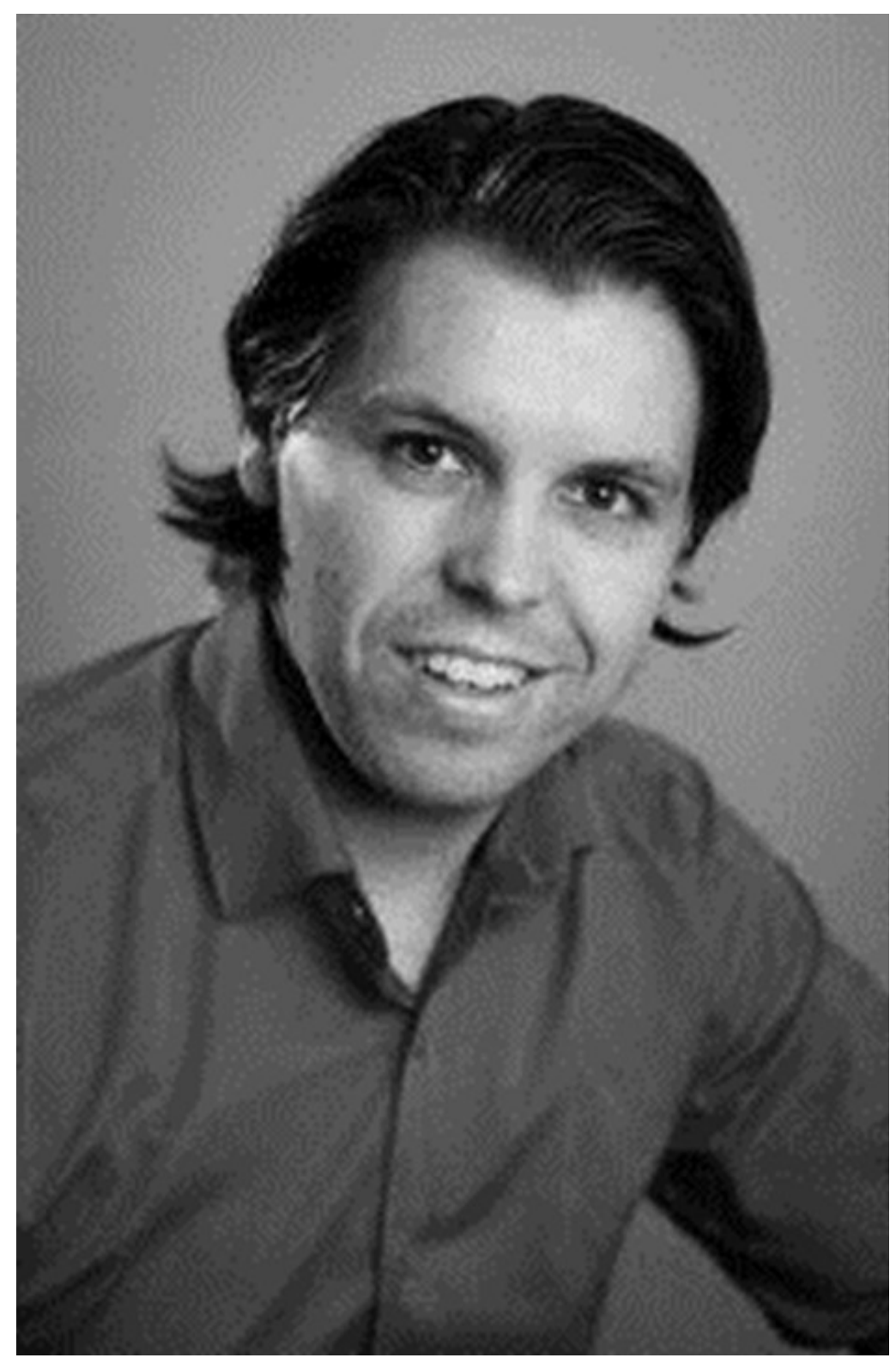

CV photos, Hélder

$124 \times 190 \mathrm{~mm}(96 \times 96 \mathrm{DPI})$

Wiley-VCH 


\begin{tabular}{|c|c|}
\hline \multicolumn{2}{|c|}{$\begin{array}{c}\text { SPRINGER NATURE LICENSE } \\
\text { TERMS AND CONDITIONS }\end{array}$} \\
\hline & Jul 01, 2019 \\
\hline \multicolumn{2}{|c|}{$\begin{array}{l}\text { This Agreement between University of Aveiro -- Tiago Carvalho ("You") and Springer } \\
\text { Nature ("Springer Nature") consists of your license details and the terms and conditions } \\
\text { provided by Springer Nature and Copyright Clearance Center. }\end{array}$} \\
\hline License Number & 4620240165736 \\
\hline License date & Jul 01, 2019 \\
\hline Licensed Content Publisher & Springer Nature \\
\hline Licensed Content Publication & Cellulose \\
\hline Licensed Content Title & $\begin{array}{l}\text { Physical properties of TEMPO-oxidized bacterial cellulose nanofibers } \\
\text { on the skin surface }\end{array}$ \\
\hline Licensed Content Author & Seung-Hyun Jun, Seol-Hoon Lee, Seoyeon Kim et al \\
\hline Licensed Content Date & $\operatorname{Jan} 1,2017$ \\
\hline Licensed Content Volume & 24 \\
\hline Licensed Content Issue & 12 \\
\hline Type of Use & Journal/Magazine \\
\hline Requestor type & academic/university or research institute \\
\hline Format & print and electronic \\
\hline Portion & figures/tables/illustrations \\
\hline $\begin{array}{l}\text { Number of figures/tables } \\
\text { /illustrations }\end{array}$ & 1 \\
\hline Will you be translating? & no \\
\hline Circulation/distribution & $>100,000$ \\
\hline $\begin{array}{l}\text { Author of this Springer } \\
\text { Nature content }\end{array}$ & no \\
\hline Title of new article & $\begin{array}{l}\text { Latest advances on bacterial cellulose-based materials for wound } \\
\text { healing, delivery systems and tissue engineering }\end{array}$ \\
\hline Lead author & $\begin{array}{l}\text { Tiago Carvalho, Gabriela Guedes, Filipa L. Sousa, Carmen S. R. } \\
\text { Freire, Hélder A. Santos }\end{array}$ \\
\hline Title of targeted journal & Biotechnology Journal \\
\hline Publisher & Wiley \\
\hline Expected publication date & Sep 2019 \\
\hline Portions & Figure 1 \\
\hline Requestor Location & $\begin{array}{l}\text { University of Aveiro } \\
\text { Campus Universitário de Santiago } \\
\text { Aveiro, Aveiro 3810-193 } \\
\text { Portugal } \\
\text { Attn: Carmen Freire }\end{array}$ \\
\hline
\end{tabular}


0.00 EUR

Terms and Conditions

\section{Springer Nature Customer Service Centre GmbH \\ Terms and Conditions}

This agreement sets out the terms and conditions of the licence (the Licence) between you and Springer Nature Customer Service Centre GmbH (the Licensor). By clicking 'accept' and completing the transaction for the material (Licensed Material), you also confirm your acceptance of these terms and conditions.

\section{Grant of License}

1. 1. The Licensor grants you a personal, non-exclusive, non-transferable, world-wide licence to reproduce the Licensed Material for the purpose specified in your order only. Licences are granted for the specific use requested in the order and for no other use, subject to the conditions below.

1. 2. The Licensor warrants that it has, to the best of its knowledge, the rights to license reuse of the Licensed Material. However, you should ensure that the material you are requesting is original to the Licensor and does not carry the copyright of another entity (as credited in the published version).

1. 3. If the credit line on any part of the material you have requested indicates that it was reprinted or adapted with permission from another source, then you should also seek permission from that source to reuse the material.

\section{Scope of Licence}

2. 1. You may only use the Licensed Content in the manner and to the extent permitted by these Ts\&Cs and any applicable laws.

2. 2. A separate licence may be required for any additional use of the Licensed Material, e.g. where a licence has been purchased for print only use, separate permission must be obtained for electronic re-use. Similarly, a licence is only valid in the language selected and does not apply for editions in other languages unless additional translation rights have been granted separately in the licence. Any content owned by third parties are expressly excluded from the licence.

2. 3. Similarly, rights for additional components such as custom editions and derivatives require additional permission and may be subject to an additional fee. Please apply to Journalpermissions@springernature.com/bookpermissions@springernature.com for these rights.

2. 4. Where permission has been granted free of charge for material in print, permission may also be granted for any electronic version of that work, provided that the material is incidental to your work as a whole and that the electronic version is essentially equivalent to, or substitutes for, the print version.

2. 5. An alternative scope of licence may apply to signatories of the STM Permissions Guidelines, as amended from time to time.

\section{Duration of Licence}

3. 1. A licence for is valid from the date of purchase ('Licence Date') at the end of the relevant period in the below table:

\begin{tabular}{|l|l||}
\hline Scope of Licence & \multicolumn{1}{|c|}{ Duration of Licence } \\
\hline Post on a website & 12 months \\
\hline
\end{tabular}




\begin{tabular}{|l|l|}
\hline Presentations & 12 months \\
\hline $\begin{array}{l}\text { Books and } \\
\text { journals }\end{array}$ & $\begin{array}{l}\text { Lifetime of the edition in the language } \\
\text { purchased }\end{array}$ \\
\hline
\end{tabular}

\section{Acknowledgement}

4. 1. The Licensor's permission must be acknowledged next to the Licenced Material in print. In electronic form, this acknowledgement must be visible at the same time as the figures/tables/illustrations or abstract, and must be hyperlinked to the journal/book's homepage. Our required acknowledgement format is in the Appendix below.

\section{Restrictions on use}

5. 1. Use of the Licensed Material may be permitted for incidental promotional use and minor editing privileges e.g. minor adaptations of single figures, changes of format, colour and/or style where the adaptation is credited as set out in Appendix 1 below. Any other changes including but not limited to, cropping, adapting, omitting material that affect the meaning, intention or moral rights of the author are strictly prohibited.

5. 2. You must not use any Licensed Material as part of any design or trademark.

5. 3. Licensed Material may be used in Open Access Publications (OAP) before publication by Springer Nature, but any Licensed Material must be removed from OAP sites prior to final publication.

\section{Ownership of Rights}

6. 1. Licensed Material remains the property of either Licensor or the relevant third party and any rights not explicitly granted herein are expressly reserved.

\section{Warranty}

IN NO EVENT SHALL LICENSOR BE LIABLE TO YOU OR ANY OTHER PARTY OR ANY OTHER PERSON OR FOR ANY SPECIAL, CONSEQUENTIAL, INCIDENTAL OR INDIRECT DAMAGES, HOWEVER CAUSED, ARISING OUT OF OR IN CONNECTION WITH THE DOWNLOADING, VIEWING OR USE OF THE MATERIALS REGARDLESS OF THE FORM OF ACTION, WHETHER FOR BREACH OF CONTRACT, BREACH OF WARRANTY, TORT, NEGLIGENCE, INFRINGEMENT OR OTHERWISE (INCLUDING, WITHOUT LIMITATION, DAMAGES BASED ON LOSS OF PROFITS, DATA, FILES, USE, BUSINESS OPPORTUNITY OR CLAIMS OF THIRD PARTIES), AND WHETHER OR NOT THE PARTY HAS BEEN ADVISED OF THE POSSIBILITY OF SUCH DAMAGES. THIS LIMITATION SHALL APPLY NOTWITHSTANDING ANY FAILURE OF ESSENTIAL PURPOSE OF ANY LIMITED REMEDY PROVIDED HEREIN.

\section{Limitations}


8. 1. BOOKS ONLY:Where 'reuse in a dissertation/thesis' has been selected the following terms apply: Print rights of the final author's accepted manuscript (for clarity, NOT the published version) for up to 100 copies, electronic rights for use only on a personal website or institutional repository as defined by the Sherpa guideline (www.sherpa.ac.uk/romeo/).

\section{Termination and Cancellation}

9. 1. Licences will expire after the period shown in Clause 3 (above).

9. 2. Licensee reserves the right to terminate the Licence in the event that payment is not received in full or if there has been a breach of this agreement by you.

\section{Appendix 1 - Acknowledgements:}

For Journal Content:

Reprinted by permission from [the Licensor]: [Journal Publisher (e.g. Nature/Springer/Palgrave)] [JOURNAL NAME] [REFERENCE CITATION (Article name, Author(s) Name), [COPYRIGHT] (year of publication)

For Advance Online Publication papers:

Reprinted by permission from [the Licensor]: [Journal Publisher (e.g. Nature/Springer/Palgrave)] [JOURNAL NAME] [REFERENCE CITATION (Article name, Author(s) Name), [COPYRIGHT] (year of publication), advance online publication, day month year (doi: 10.1038/sj.[JOURNAL ACRONYM].)

For Adaptations/Translations:

Adapted/Translated by permission from [the Licensor]: [Journal Publisher (e.g. Nature/Springer/Palgrave)] [JOURNAL NAME] [REFERENCE CITATION (Article name, Author(s) Name), [COPYRIGHT] (year of publication)

Note: For any republication from the British Journal of Cancer, the following credit line style applies:

Reprinted/adapted/translated by permission from [the Licensor]: on behalf of Cancer Research UK: : [Journal Publisher (e.g. Nature/Springer/Palgrave)] [JOURNAL NAME] [REFERENCE CITATION (Article name, Author(s) Name), [COPYRIGHT] (year of publication)

For Advance Online Publication papers:

Reprinted by permission from The [the Licensor]: on behalf of Cancer Research UK: [Journal Publisher (e.g. Nature/Springer/Palgrave)] [JOURNAL NAME] [REFERENCE CITATION (Article name, Author(s) Name), [COPYRIGHT] (year of publication), advance online publication, day month year (doi: 10.1038/sj. [JOURNAL ACRONYM])

For Book content:

Reprinted/adapted by permission from [the Licensor]: [Book Publisher (e.g. Palgrave Macmillan, Springer etc) [Book Title] by [Book author(s)]

[COPYRIGHT] (year of publication)

Other Conditions: 
Version 1.2

Questions? customercare@copyright.com or +1-855-239-3415 (toll free in the US) or +1-978-646-2777.

10

11

12

13

14

15

16

17

18

19

20

21

22

23

24

25

26

27

28

29

30

31

32

33

34

35

36

37

38

39

40

41

42

43

44

45

46

47

48

49

50

51

52

53

54

55

56

57

58

59

60

Wiley-VCH 


\section{JOHN WILEY AND SONS LICENSE TERMS AND CONDITIONS}

Jul 01, 2019

This Agreement between University of Aveiro -- Tiago Carvalho ("You") and John Wiley and Sons ("John Wiley and Sons") consists of your license details and the terms and conditions provided by John Wiley and Sons and Copyright Clearance Center.

License Number

License date

Licensed Content Publisher

Licensed Content Publication

Licensed Content Title

Licensed Content Author

Licensed Content Date

Licensed Content Volume

Licensed Content Issue

Licensed Content Pages

Type of use

Requestor type

Is the reuse sponsored by or no

associated with a

pharmaceutical or medical

products company?

Format

Print and electronic

Portion

Figure/table

Number of figures/tables

Original Wiley figure/table number(s)

Will you be translating?

Title of new article

Publication the new article is

in

Publisher of new article Wiley

Author of new article

Tiago Carvalho, Gabriela Guedes, Filipa L. Sousa, Carmen S. R. Freire, Hélder A. Santos

Expected publication date of Sep 2019

new article

Estimated size of new article 20

(pages)

Requestor Location
4620240007072

Jul 01, 2019

John Wiley and Sons

Construction of Small-Diameter Vascular Graft by Shape-Memory and Self-Rolling Bacterial Cellulose Membrane

Mar 17, 2017

11

10

Journal/Magazine

University/Academic
Figures 1 and 5

No

Latest advances on bacterial cellulose-based materials for wound healing, delivery systems and tissue engineering

Biotechnology Journal Campus Universitário de Santiago 
Aveiro, Aveiro 3810-193

Portugal

Attn: Carmen Freire

Publisher Tax ID

EU826007151

Total

0.00 EUR

Terms and Conditions

\section{TERMS AND CONDITIONS}

This copyrighted material is owned by or exclusively licensed to John Wiley \& Sons, Inc. or one of its group companies (each a"Wiley Company") or handled on behalf of a society with which a Wiley Company has exclusive publishing rights in relation to a particular work (collectively "WILEY"). By clicking "accept" in connection with completing this licensing transaction, you agree that the following terms and conditions apply to this transaction (along with the billing and payment terms and conditions established by the Copyright Clearance Center Inc., ("CCC's Billing and Payment terms and conditions"), at the time that you opened your RightsLink account (these are available at any time at http://myaccount.copyright.com).

\section{Terms and Conditions}

- The materials you have requested permission to reproduce or reuse (the "Wiley Materials") are protected by copyright.

- You are hereby granted a personal, non-exclusive, non-sub licensable (on a standalone basis), non-transferable, worldwide, limited license to reproduce the Wiley Materials for the purpose specified in the licensing process. This license, and any CONTENT (PDF or image file) purchased as part of your order, is for a one-time use only and limited to any maximum distribution number specified in the license. The first instance of republication or reuse granted by this license must be completed within two years of the date of the grant of this license (although copies prepared before the end date may be distributed thereafter). The Wiley Materials shall not be used in any other manner or for any other purpose, beyond what is granted in the license. Permission is granted subject to an appropriate acknowledgement given to the author, title of the material/book/journal and the publisher. You shall also duplicate the copyright notice that appears in the Wiley publication in your use of the Wiley Material. Permission is also granted on the understanding that nowhere in the text is a previously published source acknowledged for all or part of this Wiley Material. Any third party content is expressly excluded from this permission.

- With respect to the Wiley Materials, all rights are reserved. Except as expressly granted by the terms of the license, no part of the Wiley Materials may be copied, modified, adapted (except for minor reformatting required by the new Publication), translated, reproduced, transferred or distributed, in any form or by any means, and no derivative works may be made based on the Wiley Materials without the prior permission of the respective copyright owner.For STM Signatory Publishers clearing permission under the terms of the STM Permissions Guidelines only, the terms of the license are extended to include subsequent editions and for editions in other languages, provided such editions are for the work as a whole in situ and does not involve the separate exploitation of the permitted figures or extracts, You may not alter, remove or suppress in any manner any copyright, trademark or 
other notices displayed by the Wiley Materials. You may not license, rent, sell, loan, lease, pledge, offer as security, transfer or assign the Wiley Materials on a stand-alone basis, or any of the rights granted to you hereunder to any other person.

- The Wiley Materials and all of the intellectual property rights therein shall at all times remain the exclusive property of John Wiley \& Sons Inc, the Wiley Companies, or their respective licensors, and your interest therein is only that of having possession of and the right to reproduce the Wiley Materials pursuant to Section 2 herein during the continuance of this Agreement. You agree that you own no right, title or interest in or to the Wiley Materials or any of the intellectual property rights therein. You shall have no rights hereunder other than the license as provided for above in Section 2. No right, license or interest to any trademark, trade name, service mark or other branding ("Marks") of WILEY or its licensors is granted hereunder, and you agree that you shall not assert any such right, license or interest with respect thereto

- NEITHER WILEY NOR ITS LICENSORS MAKES ANY WARRANTY OR REPRESENTATION OF ANY KIND TO YOU OR ANY THIRD PARTY, EXPRESS, IMPLIED OR STATUTORY, WITH RESPECT TO THE MATERIALS OR THE ACCURACY OF ANY INFORMATION CONTAINED IN THE MATERIALS, INCLUDING, WITHOUT LIMITATION, ANY IMPLIED WARRANTY OF MERCHANTABILITY, ACCURACY, SATISFACTORY QUALITY, FITNESS FOR A PARTICULAR PURPOSE, USABILITY, INTEGRATION OR NON-INFRINGEMENT AND ALL SUCH WARRANTIES ARE HEREBY EXCLUDED BY WILEY AND ITS LICENSORS AND WAIVED BY YOU.

- WILEY shall have the right to terminate this Agreement immediately upon breach of this Agreement by you.

- You shall indemnify, defend and hold harmless WILEY, its Licensors and their respective directors, officers, agents and employees, from and against any actual or threatened claims, demands, causes of action or proceedings arising from any breach of this Agreement by you.

- IN NO EVENT SHALL WILEY OR ITS LICENSORS BE LIABLE TO YOU OR ANY OTHER PARTY OR ANY OTHER PERSON OR ENTITY FOR ANY SPECIAL, CONSEQUENTIAL, INCIDENTAL, INDIRECT, EXEMPLARY OR PUNITIVE DAMAGES, HOWEVER CAUSED, ARISING OUT OF OR IN CONNECTION WITH THE DOWNLOADING, PROVISIONING, VIEWING OR USE OF THE MATERIALS REGARDLESS OF THE FORM OF ACTION, WHETHER FOR BREACH OF CONTRACT, BREACH OF WARRANTY, TORT, NEGLIGENCE, INFRINGEMENT OR OTHERWISE (INCLUDING, WITHOUT LIMITATION, DAMAGES BASED ON LOSS OF PROFITS, DATA, FILES, USE, BUSINESS OPPORTUNITY OR CLAIMS OF THIRD PARTIES), AND WHETHER OR NOT THE PARTY HAS BEEN ADVISED OF THE POSSIBILITY OF SUCH DAMAGES. THIS LIMITATION SHALL APPLY NOTWITHSTANDING ANY FAILURE OF ESSENTIAL PURPOSE OF ANY LIMITED REMEDY PROVIDED HEREIN.

- Should any provision of this Agreement be held by a court of competent jurisdiction 
to be illegal, invalid, or unenforceable, that provision shall be deemed amended to achieve as nearly as possible the same economic effect as the original provision, and the legality, validity and enforceability of the remaining provisions of this Agreement shall not be affected or impaired thereby.

- The failure of either party to enforce any term or condition of this Agreement shall not constitute a waiver of either party's right to enforce each and every term and condition of this Agreement. No breach under this agreement shall be deemed waived or excused by either party unless such waiver or consent is in writing signed by the party granting such waiver or consent. The waiver by or consent of a party to a breach of any provision of this Agreement shall not operate or be construed as a waiver of or consent to any other or subsequent breach by such other party.

- This Agreement may not be assigned (including by operation of law or otherwise) by you without WILEY's prior written consent.

- Any fee required for this permission shall be non-refundable after thirty (30) days from receipt by the $\mathrm{CCC}$.

- These terms and conditions together with CCC's Billing and Payment terms and conditions (which are incorporated herein) form the entire agreement between you and WILEY concerning this licensing transaction and (in the absence of fraud) supersedes all prior agreements and representations of the parties, oral or written. This Agreement may not be amended except in writing signed by both parties. This Agreement shall be binding upon and inure to the benefit of the parties' successors, legal representatives, and authorized assigns.

- In the event of any conflict between your obligations established by these terms and conditions and those established by CCC's Billing and Payment terms and conditions, these terms and conditions shall prevail.

- WILEY expressly reserves all rights not specifically granted in the combination of (i) the license details provided by you and accepted in the course of this licensing transaction, (ii) these terms and conditions and (iii) CCC's Billing and Payment terms and conditions.

- This Agreement will be void if the Type of Use, Format, Circulation, or Requestor Type was misrepresented during the licensing process.

- This Agreement shall be governed by and construed in accordance with the laws of the State of New York, USA, without regards to such state's conflict of law rules. Any legal action, suit or proceeding arising out of or relating to these Terms and Conditions or the breach thereof shall be instituted in a court of competent jurisdiction in New York County in the State of New York in the United States of America and each party hereby consents and submits to the personal jurisdiction of such court, waives any objection to venue in such court and consents to service of process by registered or certified mail, return receipt requested, at the last known address of such party.

\section{WILEY OPEN ACCESS TERMS AND CONDITIONS}

Wiley Publishes Open Access Articles in fully Open Access Journals and in Subscription Wiley-VCH 
journals offering Online Open. Although most of the fully Open Access journals publish open access articles under the terms of the Creative Commons Attribution (CC BY) License only, the subscription journals and a few of the Open Access Journals offer a choice of Creative Commons Licenses. The license type is clearly identified on the article.

The Creative Commons Attribution License

The Creative Commons Attribution License (CC-BY) allows users to copy, distribute and transmit an article, adapt the article and make commercial use of the article. The CC-BY license permits commercial and non-

Creative Commons Attribution Non-Commercial License

The Creative Commons Attribution Non-Commercial (CC-BY-NC)License permits use, distribution and reproduction in any medium, provided the original work is properly cited and is not used for commercial purposes.(see below)

\title{
Creative Commons Attribution-Non-Commercial-NoDerivs License
}

The Creative Commons Attribution Non-Commercial-NoDerivs License (CC-BY-NC-ND) permits use, distribution and reproduction in any medium, provided the original work is properly cited, is not used for commercial purposes and no modifications or adaptations are made. (see below)

Use by commercial "for-profit" organizations

Use of Wiley Open Access articles for commercial, promotional, or marketing purposes requires further explicit permission from Wiley and will be subject to a fee.

Further details can be found on Wiley Online Library http://olabout.wiley.com/WileyCDA

/Section/id-410895.html

\section{Other Terms and Conditions:}

\author{
v1.10 Last updated September 2015 \\ Questions? customercare@copyright.com or +1-855-239-3415 (toll free in the US) or \\ +1-978-646-2777.
}




\section{ELSEVIER LICENSE TERMS AND CONDITIONS}

Jul 01, 2019

This Agreement between University of Aveiro -- Tiago Carvalho ("You") and Elsevier ("Elsevier") consists of your license details and the terms and conditions provided by Elsevier and Copyright Clearance Center.

License Number

License date

Licensed Content Publisher

Licensed Content Publication

Licensed Content Title

Licensed Content Author

Licensed Content Date

Licensed Content Volume

Licensed Content Issue

Licensed Content Pages

Start Page

End Page

Type of Use

Requestor type

Intended publisher of new work

Portion

Number of figures/tables

/illustrations

Format

Are you the author of this Elsevier article?

Will you be translating?

Original figure numbers

Title of the article

Publication new article is in

Publisher of the new article

Author of new article

Expected publication date

Estimated size of new article 20

(number of pages)

1
4620240310803

Jul 01, 2019

Elsevier

Biomaterials

Fabrication of nanofibrous microcarriers mimicking extracellular matrix for functional microtissue formation and cartilage regeneration

Yansen Wang,Xueling Yuan, Kun Yu,Haoye Meng,Yudong Zheng,Jiang Peng,Shibi Lu,Xiaotong Liu,Yajie Xie,Kun Qiao

Jul 1, 2018

171

$\mathrm{n} / \mathrm{a}$

15

118

132

reuse in a journal/magazine

academic/educational institute

Wiley

figures/tables/illustrations

both print and electronic

No

No

Figure 2

Latest advances on bacterial cellulose-based materials for wound healing, delivery systems and tissue engineering

Biotechnology Journal

Wiley

Tiago Carvalho, Gabriela Guedes, Filipa L. Sousa, Carmen S. R. Freire, Hélder A. Santos

Sep 2019 
$\begin{array}{ll}\text { Requestor Location } & \text { University of Aveiro } \\ \text { Campus Universitário de Santiago }\end{array}$

Aveiro, Aveiro 3810-193

Portugal

Attn: Carmen Freire

Publisher Tax ID

GB 494627212

Total

0.00 EUR

Terms and Conditions

\section{INTRODUCTION}

1. The publisher for this copyrighted material is Elsevier. By clicking "accept" in connection with completing this licensing transaction, you agree that the following terms and conditions apply to this transaction (along with the Billing and Payment terms and conditions established by Copyright Clearance Center, Inc. ("CCC"), at the time that you opened your Rightslink account and that are available at any time at http://myaccount.copyright.com).

\section{GENERAL TERMS}

2. Elsevier hereby grants you permission to reproduce the aforementioned material subject to the terms and conditions indicated.

3. Acknowledgement: If any part of the material to be used (for example, figures) has appeared in our publication with credit or acknowledgement to another source, permission must also be sought from that source. If such permission is not obtained then that material may not be included in your publication/copies. Suitable acknowledgement to the source must be made, either as a footnote or in a reference list at the end of your publication, as follows:

"Reprinted from Publication title, Vol /edition number, Author(s), Title of article / title of chapter, Pages No., Copyright (Year), with permission from Elsevier [OR APPLICABLE SOCIETY COPYRIGHT OWNER]." Also Lancet special credit - "Reprinted from The Lancet, Vol. number, Author(s), Title of article, Pages No., Copyright (Year), with permission from Elsevier."

4. Reproduction of this material is confined to the purpose and/or media for which permission is hereby given.

5. Altering/Modifying Material: Not Permitted. However figures and illustrations may be altered/adapted minimally to serve your work. Any other abbreviations, additions, deletions and/or any other alterations shall be made only with prior written authorization of Elsevier Ltd. (Please contact Elsevier at permissions@elsevier.com). No modifications can be made to any Lancet figures/tables and they must be reproduced in full.

6. If the permission fee for the requested use of our material is waived in this instance, please be advised that your future requests for Elsevier materials may attract a fee.

7. Reservation of Rights: Publisher reserves all rights not specifically granted in the combination of (i) the license details provided by you and accepted in the course of this licensing transaction, (ii) these terms and conditions and (iii) CCC's Billing and Payment terms and conditions.

8. License Contingent Upon Payment: While you may exercise the rights licensed immediately upon issuance of the license at the end of the licensing process for the transaction, provided that you have disclosed complete and accurate details of your proposed use, no license is finally effective unless and until full payment is received from you (either by publisher or by CCC) as provided in CCC's Billing and Payment terms and conditions. If full payment is not received on a timely basis, then any license preliminarily granted shall be deemed automatically revoked and shall be void as if never granted. Further, in the event 
that you breach any of these terms and conditions or any of CCC's Billing and Payment terms and conditions, the license is automatically revoked and shall be void as if never granted. Use of materials as described in a revoked license, as well as any use of the materials beyond the scope of an unrevoked license, may constitute copyright infringement and publisher reserves the right to take any and all action to protect its copyright in the materials.

9. Warranties: Publisher makes no representations or warranties with respect to the licensed material.

10. Indemnity: You hereby indemnify and agree to hold harmless publisher and CCC, and their respective officers, directors, employees and agents, from and against any and all claims arising out of your use of the licensed material other than as specifically authorized pursuant to this license.

11. No Transfer of License: This license is personal to you and may not be sublicensed, assigned, or transferred by you to any other person without publisher's written permission. 12. No Amendment Except in Writing: This license may not be amended except in a writing signed by both parties (or, in the case of publisher, by CCC on publisher's behalf).

13. Objection to Contrary Terms: Publisher hereby objects to any terms contained in any purchase order, acknowledgment, check endorsement or other writing prepared by you, which terms are inconsistent with these terms and conditions or CCC's Billing and Payment terms and conditions. These terms and conditions, together with CCC's Billing and Payment terms and conditions (which are incorporated herein), comprise the entire agreement between you and publisher (and CCC) concerning this licensing transaction. In the event of any conflict between your obligations established by these terms and conditions and those established by CCC's Billing and Payment terms and conditions, these terms and conditions shall control.

14. Revocation: Elsevier or Copyright Clearance Center may deny the permissions described in this License at their sole discretion, for any reason or no reason, with a full refund payable to you. Notice of such denial will be made using the contact information provided by you. Failure to receive such notice will not alter or invalidate the denial. In no event will Elsevier or Copyright Clearance Center be responsible or liable for any costs, expenses or damage incurred by you as a result of a denial of your permission request, other than a refund of the amount(s) paid by you to Elsevier and/or Copyright Clearance Center for denied permissions.

\section{LIMITED LICENSE}

The following terms and conditions apply only to specific license types:

15. Translation: This permission is granted for non-exclusive world English rights only unless your license was granted for translation rights. If you licensed translation rights you may only translate this content into the languages you requested. A professional translator must perform all translations and reproduce the content word for word preserving the integrity of the article.

16. Posting licensed content on any Website: The following terms and conditions apply as follows: Licensing material from an Elsevier journal: All content posted to the web site must maintain the copyright information line on the bottom of each image; A hyper-text must be included to the Homepage of the journal from which you are licensing at http://www.sciencedirect.com/science/journal/xxxxx or the Elsevier homepage for books at http://www.elsevier.com; Central Storage: This license does not include permission for a scanned version of the material to be stored in a central repository such as that provided by Heron/XanEdu.

Licensing material from an Elsevier book: A hyper-text link must be included to the Elsevier homepage at http://www.elsevier.com . All content posted to the web site must maintain the 
copyright information line on the bottom of each image.

Posting licensed content on Electronic reserve: In addition to the above the following clauses are applicable: The web site must be password-protected and made available only to bona fide students registered on a relevant course. This permission is granted for 1 year only. You may obtain a new license for future website posting.

17. For journal authors: the following clauses are applicable in addition to the above: Preprints:

A preprint is an author's own write-up of research results and analysis, it has not been peerreviewed, nor has it had any other value added to it by a publisher (such as formatting, copyright, technical enhancement etc.).

Authors can share their preprints anywhere at any time. Preprints should not be added to or enhanced in any way in order to appear more like, or to substitute for, the final versions of articles however authors can update their preprints on arXiv or RePEc with their Accepted Author Manuscript (see below).

If accepted for publication, we encourage authors to link from the preprint to their formal publication via its DOI. Millions of researchers have access to the formal publications on ScienceDirect, and so links will help users to find, access, cite and use the best available version. Please note that Cell Press, The Lancet and some society-owned have different preprint policies. Information on these policies is available on the journal homepage.

Accepted Author Manuscripts: An accepted author manuscript is the manuscript of an article that has been accepted for publication and which typically includes authorincorporated changes suggested during submission, peer review and editor-author communications.

Authors can share their accepted author manuscript:

- immediately

$\circ$ via their non-commercial person homepage or blog

- by updating a preprint in arXiv or RePEc with the accepted manuscript

o via their research institute or institutional repository for internal institutional uses or as part of an invitation-only research collaboration work-group

o directly by providing copies to their students or to research collaborators for their personal use

- for private scholarly sharing as part of an invitation-only work group on commercial sites with which Elsevier has an agreement

- After the embargo period

o via non-commercial hosting platforms such as their institutional repository

o via commercial sites with which Elsevier has an agreement

In all cases accepted manuscripts should:

- link to the formal publication via its DOI

- bear a CC-BY-NC-ND license - this is easy to do

- if aggregated with other manuscripts, for example in a repository or other site, be shared in alignment with our hosting policy not be added to or enhanced in any way to appear more like, or to substitute for, the published journal article.

Published journal article (JPA): A published journal article (PJA) is the definitive final record of published research that appears or will appear in the journal and embodies all value-adding publishing activities including peer review co-ordination, copy-editing, formatting, (if relevant) pagination and online enrichment. 
Policies for sharing publishing journal articles differ for subscription and gold open access articles:

Subscription Articles: If you are an author, please share a link to your article rather than the full-text. Millions of researchers have access to the formal publications on ScienceDirect, and so links will help your users to find, access, cite, and use the best available version. Theses and dissertations which contain embedded PJAs as part of the formal submission can be posted publicly by the awarding institution with DOI links back to the formal publications on ScienceDirect.

If you are affiliated with a library that subscribes to ScienceDirect you have additional private sharing rights for others' research accessed under that agreement. This includes use for classroom teaching and internal training at the institution (including use in course packs and courseware programs), and inclusion of the article for grant funding purposes.

Gold Open Access Articles: May be shared according to the author-selected end-user license and should contain a CrossMark logo, the end user license, and a DOI link to the formal publication on ScienceDirect.

Please refer to Elsevier's posting policy for further information.

18. For book authors the following clauses are applicable in addition to the above: Authors are permitted to place a brief summary of their work online only. You are not allowed to download and post the published electronic version of your chapter, nor may you scan the printed edition to create an electronic version. Posting to a repository: Authors are permitted to post a summary of their chapter only in their institution's repository.

19. Thesis/Dissertation: If your license is for use in a thesis/dissertation your thesis may be submitted to your institution in either print or electronic form. Should your thesis be published commercially, please reapply for permission. These requirements include permission for the Library and Archives of Canada to supply single copies, on demand, of the complete thesis and include permission for Proquest/UMI to supply single copies, on demand, of the complete thesis. Should your thesis be published commercially, please reapply for permission. Theses and dissertations which contain embedded PJAs as part of the formal submission can be posted publicly by the awarding institution with DOI links back to the formal publications on ScienceDirect.

\section{Elsevier Open Access Terms and Conditions}

You can publish open access with Elsevier in hundreds of open access journals or in nearly 2000 established subscription journals that support open access publishing. Permitted third party re-use of these open access articles is defined by the author's choice of Creative Commons user license. See our open access license policy for more information.

Terms \& Conditions applicable to all Open Access articles published with Elsevier: Any reuse of the article must not represent the author as endorsing the adaptation of the article nor should the article be modified in such a way as to damage the author's honour or reputation. If any changes have been made, such changes must be clearly indicated. The author(s) must be appropriately credited and we ask that you include the end user license and a DOI link to the formal publication on ScienceDirect.

If any part of the material to be used (for example, figures) has appeared in our publication with credit or acknowledgement to another source it is the responsibility of the user to ensure their reuse complies with the terms and conditions determined by the rights holder.

Additional Terms \& Conditions applicable to each Creative Commons user license: CC BY: The CC-BY license allows users to copy, to create extracts, abstracts and new works from the Article, to alter and revise the Article and to make commercial use of the Article (including reuse and/or resale of the Article by commercial entities), provided the user gives appropriate credit (with a link to the formal publication through the relevant 
DOI), provides a link to the license, indicates if changes were made and the licensor is not represented as endorsing the use made of the work. The full details of the license are available at http://creativecommons.org/licenses/by/4.0.

CC BY NC SA: The CC BY-NC-SA license allows users to copy, to create extracts, abstracts and new works from the Article, to alter and revise the Article, provided this is not done for commercial purposes, and that the user gives appropriate credit (with a link to the formal publication through the relevant DOI), provides a link to the license, indicates if changes were made and the licensor is not represented as endorsing the use made of the work. Further, any new works must be made available on the same conditions. The full details of the license are available at http://creativecommons.org/licenses/by-nc-sa/4.0.

CC BY NC ND: The CC BY-NC-ND license allows users to copy and distribute the Article, provided this is not done for commercial purposes and further does not permit distribution of the Article if it is changed or edited in any way, and provided the user gives appropriate credit (with a link to the formal publication through the relevant DOI), provides a link to the license, and that the licensor is not represented as endorsing the use made of the work. The full details of the license are available at http://creativecommons.org/licenses/by-nc-nd/4.0. Any commercial reuse of Open Access articles published with a CC BY NC SA or CC BY $\mathrm{NC}$ ND license requires permission from Elsevier and will be subject to a fee. Commercial reuse includes:

- Associating advertising with the full text of the Article

- Charging fees for document delivery or access

- Article aggregation

- Systematic distribution via e-mail lists or share buttons

Posting or linking by commercial companies for use by customers of those companies.

\section{Other Conditions:}

v1.9

Questions? customercare@copyright.com or +1-855-239-3415 (toll free in the US) or +1-978-646-2777. 


\section{Copyright Clearance Center

\section{ACSPublications Title:}

Most Trusted. Most Cited. Most Read.

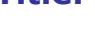

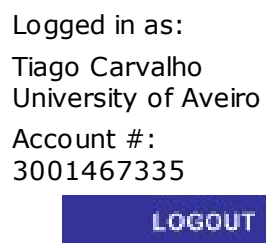

\section{PERMISSION/LICENSE IS GRANTED FOR YOUR ORDER AT NO CHARGE}

This type of permission/license, instead of the standard Terms \& Conditions, is sent to you because no fee is being charged for your order. Please note the following:

- Permission is granted for your request in both print and electronic formats, and translations.

- If figures and/or tables were requested, they may be adapted or used in part.

- Please print this page for your records and send a copy of it to your publisher/graduate school.

- Appropriate credit for the requested material should be given as follows: "Reprinted (adapted) with permission from (COMPLETE REFERENCE CITATION). Copyright (YEAR) American Chemical Society." Insert appropriate information in place of the capitalized words.

- One-time permission is granted only for the use specified in your request. No additional uses are granted (such as derivative works or other editions). For any other uses, please submit a new request.

If credit is given to another source for the material you requested, permission must be obtained from that source.

\section{BACK}

\section{CLOSE WINDOW}

Copyright (c) 2019 Copyright Clearance Center, Inc. All Rights Reserved. Privacy statement. Terms and Conditions. Comments? We would like to hear from you. E-mail us at customercare@copyright.com 


\section{JOHN WILEY AND SONS LICENSE TERMS AND CONDITIONS}

Jul 01, 2019

This Agreement between University of Aveiro -- Tiago Carvalho ("You") and John Wiley and Sons ("John Wiley and Sons") consists of your license details and the terms and conditions provided by John Wiley and Sons and Copyright Clearance Center.

License Number

License date

Licensed Content Publisher

Licensed Content Publication Small

Licensed Content Title

Reverse Reconstruction and Bioprinting of Bacterial Cellulose-Based Functional Total Intervertebral Disc for Therapeutic Implantation

Licensed Content Author Junchuan Yang, Le Wang, Wei Zhang, et al

Licensed Content Date

Dec 19, 2017

Licensed Content Volume

14

Licensed Content Issue

7

Licensed Content Pages

Type of use

9

Requestor type

Journal/Magazine

University/Academic

Is the reuse sponsored by or no associated with a pharmaceutical or medical products company?

Format

Print and electronic

Portion

Figure/table

Number of figures/tables

1

Original Wiley figure/table number(s)

Figure 1

Will you be translating?

No

Title of new article

Latest advances on bacterial cellulose-based materials for wound healing, delivery systems and tissue engineering

Publication the new article is Biotechnology Journal

in

Publisher of new article Wiley

Author of new article Tiago Carvalho, Gabriela Guedes, Filipa L. Sousa, Carmen S. R. Freire, Hélder A. Santos

Expected publication date of Sep 2019

new article

Estimated size of new article 20

(pages)

Requestor Location

University of Aveiro

Campus Universitário de Santiago

Wiley-VCH 
Aveiro, Aveiro 3810-193

Portugal

Attn: Carmen Freire

Publisher Tax ID

EU826007151

Total

0.00 EUR

Terms and Conditions

\section{TERMS AND CONDITIONS}

This copyrighted material is owned by or exclusively licensed to John Wiley \& Sons, Inc. or one of its group companies (each a"Wiley Company") or handled on behalf of a society with which a Wiley Company has exclusive publishing rights in relation to a particular work (collectively "WILEY"). By clicking "accept" in connection with completing this licensing transaction, you agree that the following terms and conditions apply to this transaction (along with the billing and payment terms and conditions established by the Copyright Clearance Center Inc., ("CCC's Billing and Payment terms and conditions"), at the time that you opened your RightsLink account (these are available at any time at http://myaccount.copyright.com).

\section{Terms and Conditions}

- The materials you have requested permission to reproduce or reuse (the "Wiley Materials") are protected by copyright.

- You are hereby granted a personal, non-exclusive, non-sub licensable (on a standalone basis), non-transferable, worldwide, limited license to reproduce the Wiley Materials for the purpose specified in the licensing process. This license, and any CONTENT (PDF or image file) purchased as part of your order, is for a one-time use only and limited to any maximum distribution number specified in the license. The first instance of republication or reuse granted by this license must be completed within two years of the date of the grant of this license (although copies prepared before the end date may be distributed thereafter). The Wiley Materials shall not be used in any other manner or for any other purpose, beyond what is granted in the license. Permission is granted subject to an appropriate acknowledgement given to the author, title of the material/book/journal and the publisher. You shall also duplicate the copyright notice that appears in the Wiley publication in your use of the Wiley Material. Permission is also granted on the understanding that nowhere in the text is a previously published source acknowledged for all or part of this Wiley Material. Any third party content is expressly excluded from this permission.

- With respect to the Wiley Materials, all rights are reserved. Except as expressly granted by the terms of the license, no part of the Wiley Materials may be copied, modified, adapted (except for minor reformatting required by the new Publication), translated, reproduced, transferred or distributed, in any form or by any means, and no derivative works may be made based on the Wiley Materials without the prior permission of the respective copyright owner.For STM Signatory Publishers clearing permission under the terms of the STM Permissions Guidelines only, the terms of the license are extended to include subsequent editions and for editions in other languages, provided such editions are for the work as a whole in situ and does not involve the separate exploitation of the permitted figures or extracts, You may not alter, remove or suppress in any manner any copyright, trademark or 
other notices displayed by the Wiley Materials. You may not license, rent, sell, loan, lease, pledge, offer as security, transfer or assign the Wiley Materials on a stand-alone basis, or any of the rights granted to you hereunder to any other person.

- The Wiley Materials and all of the intellectual property rights therein shall at all times remain the exclusive property of John Wiley \& Sons Inc, the Wiley Companies, or their respective licensors, and your interest therein is only that of having possession of and the right to reproduce the Wiley Materials pursuant to Section 2 herein during the continuance of this Agreement. You agree that you own no right, title or interest in or to the Wiley Materials or any of the intellectual property rights therein. You shall have no rights hereunder other than the license as provided for above in Section 2. No right, license or interest to any trademark, trade name, service mark or other branding ("Marks") of WILEY or its licensors is granted hereunder, and you agree that you shall not assert any such right, license or interest with respect thereto

- NEITHER WILEY NOR ITS LICENSORS MAKES ANY WARRANTY OR REPRESENTATION OF ANY KIND TO YOU OR ANY THIRD PARTY, EXPRESS, IMPLIED OR STATUTORY, WITH RESPECT TO THE MATERIALS OR THE ACCURACY OF ANY INFORMATION CONTAINED IN THE MATERIALS, INCLUDING, WITHOUT LIMITATION, ANY IMPLIED WARRANTY OF MERCHANTABILITY, ACCURACY, SATISFACTORY QUALITY, FITNESS FOR A PARTICULAR PURPOSE, USABILITY, INTEGRATION OR NON-INFRINGEMENT AND ALL SUCH WARRANTIES ARE HEREBY EXCLUDED BY WILEY AND ITS LICENSORS AND WAIVED BY YOU.

- WILEY shall have the right to terminate this Agreement immediately upon breach of this Agreement by you.

- You shall indemnify, defend and hold harmless WILEY, its Licensors and their respective directors, officers, agents and employees, from and against any actual or threatened claims, demands, causes of action or proceedings arising from any breach of this Agreement by you.

- IN NO EVENT SHALL WILEY OR ITS LICENSORS BE LIABLE TO YOU OR ANY OTHER PARTY OR ANY OTHER PERSON OR ENTITY FOR ANY SPECIAL, CONSEQUENTIAL, INCIDENTAL, INDIRECT, EXEMPLARY OR PUNITIVE DAMAGES, HOWEVER CAUSED, ARISING OUT OF OR IN CONNECTION WITH THE DOWNLOADING, PROVISIONING, VIEWING OR USE OF THE MATERIALS REGARDLESS OF THE FORM OF ACTION, WHETHER FOR BREACH OF CONTRACT, BREACH OF WARRANTY, TORT, NEGLIGENCE, INFRINGEMENT OR OTHERWISE (INCLUDING, WITHOUT LIMITATION, DAMAGES BASED ON LOSS OF PROFITS, DATA, FILES, USE, BUSINESS OPPORTUNITY OR CLAIMS OF THIRD PARTIES), AND WHETHER OR NOT THE PARTY HAS BEEN ADVISED OF THE POSSIBILITY OF SUCH DAMAGES. THIS LIMITATION SHALL APPLY NOTWITHSTANDING ANY FAILURE OF ESSENTIAL PURPOSE OF ANY LIMITED REMEDY PROVIDED HEREIN.

- Should any provision of this Agreement be held by a court of competent jurisdiction 
to be illegal, invalid, or unenforceable, that provision shall be deemed amended to achieve as nearly as possible the same economic effect as the original provision, and the legality, validity and enforceability of the remaining provisions of this Agreement shall not be affected or impaired thereby.

- The failure of either party to enforce any term or condition of this Agreement shall not constitute a waiver of either party's right to enforce each and every term and condition of this Agreement. No breach under this agreement shall be deemed waived or excused by either party unless such waiver or consent is in writing signed by the party granting such waiver or consent. The waiver by or consent of a party to a breach of any provision of this Agreement shall not operate or be construed as a waiver of or consent to any other or subsequent breach by such other party.

- This Agreement may not be assigned (including by operation of law or otherwise) by you without WILEY's prior written consent.

- Any fee required for this permission shall be non-refundable after thirty (30) days from receipt by the $\mathrm{CCC}$.

- These terms and conditions together with CCC's Billing and Payment terms and conditions (which are incorporated herein) form the entire agreement between you and WILEY concerning this licensing transaction and (in the absence of fraud) supersedes all prior agreements and representations of the parties, oral or written. This Agreement may not be amended except in writing signed by both parties. This Agreement shall be binding upon and inure to the benefit of the parties' successors, legal representatives, and authorized assigns.

- In the event of any conflict between your obligations established by these terms and conditions and those established by CCC's Billing and Payment terms and conditions, these terms and conditions shall prevail.

- WILEY expressly reserves all rights not specifically granted in the combination of (i) the license details provided by you and accepted in the course of this licensing transaction, (ii) these terms and conditions and (iii) CCC's Billing and Payment terms and conditions.

- This Agreement will be void if the Type of Use, Format, Circulation, or Requestor Type was misrepresented during the licensing process.

- This Agreement shall be governed by and construed in accordance with the laws of the State of New York, USA, without regards to such state's conflict of law rules. Any legal action, suit or proceeding arising out of or relating to these Terms and Conditions or the breach thereof shall be instituted in a court of competent jurisdiction in New York County in the State of New York in the United States of America and each party hereby consents and submits to the personal jurisdiction of such court, waives any objection to venue in such court and consents to service of process by registered or certified mail, return receipt requested, at the last known address of such party.

\section{WILEY OPEN ACCESS TERMS AND CONDITIONS}

Wiley Publishes Open Access Articles in fully Open Access Journals and in Subscription Wiley-VCH 
journals offering Online Open. Although most of the fully Open Access journals publish open access articles under the terms of the Creative Commons Attribution (CC BY) License only, the subscription journals and a few of the Open Access Journals offer a choice of Creative Commons Licenses. The license type is clearly identified on the article.

\title{
The Creative Commons Attribution License
}

The Creative Commons Attribution License (CC-BY) allows users to copy, distribute and transmit an article, adapt the article and make commercial use of the article. The CC-BY license permits commercial and non-

\section{Creative Commons Attribution Non-Commercial License}

The Creative Commons Attribution Non-Commercial (CC-BY-NC)License permits use, distribution and reproduction in any medium, provided the original work is properly cited and is not used for commercial purposes.(see below)

\section{Creative Commons Attribution-Non-Commercial-NoDerivs License}

The Creative Commons Attribution Non-Commercial-NoDerivs License (CC-BY-NC-ND) permits use, distribution and reproduction in any medium, provided the original work is properly cited, is not used for commercial purposes and no modifications or adaptations are made. (see below)

Use by commercial "for-profit" organizations

Use of Wiley Open Access articles for commercial, promotional, or marketing purposes requires further explicit permission from Wiley and will be subject to a fee.

Further details can be found on Wiley Online Library http://olabout.wiley.com/WileyCDA /Section/id-410895.html

\section{Other Terms and Conditions:}

\author{
v1.10 Last updated September 2015 \\ Questions? customercare@copyright.com or +1-855-239-3415 (toll free in the US) or \\ +1-978-646-2777.
}

